MARIA HERCÍLIA DA SILVA

Modelo de procedimentos para elaboração de Metodologia de Valoração Econômica de Impactos Ambientais em Bacia Hidrográfica Estudo de Caso - Guarapiranga - aplicação da função dose-resposta

Dissertação apresentada à Escola Politécnica da Universidade de São Paulo para obtenção do Título de Mestre em Engenharia 
MARIA HERCÍLIA DA SILVA

Modelo de procedimentos para elaboração de Metodologia de Valoração Econômica de Impactos Ambientais em Bacia Hidrográfica Estudo de Caso - Guarapiranga - aplicação da função dose-resposta

Dissertação apresentada à Escola Politécnica da Universidade de São Paulo para obtenção do Título de Mestre em Engenharia

Área de Concentração: Engenharia Hidráulica Orientador: Profo. Dr. Luís César Souza Pinto 
Aos meus pais,

Bernarda e Luiz que são o que pretendo ser... exemplo de amor, dedicação, honestidade e vida. 


\section{AGRADECIMENTOS}

A Deus, pela vida, pela força e persistência nos momentos mais difíceis.

Ao meu esposo, Nadson Novais dos Santos, pelo amor e por fazer parte de minha vida.

Aos meus irmãos José Luís e Anunciata...

Ao Prof. Dr. Luís César Souza Pinto pela orientação deste trabalho.

A todos da Cetesb que contribuíram prontamente com informações.

A Ana Lúcia Silva, da Sabesp, pela prontidão e disponibilização de material para elaboração deste trabalho.

A Márcia Maria do Nascimento, da Secretaria de Estado do Meio Ambiente, pela prontidão para informações e esclarecimentos.

A todos os amigos e colegas que contribuíram direta ou indiretamente para o desenvolvimento deste trabalho. 
“A urbanização é um poderoso fator de pressão sobre os ecossistemas. $O$ meio ambiente abastece as demandas crescentes das populações e das atividades econômicas dos centros urbanos e, ainda recebe de volta os resíduos da utilização dos seus recursos naturais" (Metodologia para elaboração de Informes GEO Cidades, Manual de Aplicação, p.7 apud GEO Cidades, 2004). 


\section{RESUMO}

Este trabalho apresenta a análise dos resultados obtidos, através de pesquisa bibliográfica, sobre o uso dos recursos hídricos na Bacia Hidrográfica do Guarapiranga na Região Metropolitana de São Paulo, cujo uso prioritário é o Abastecimento Público. Identifica os impactos decorrentes tanto pela ocupação desordenada, quanto pela sobreposição de outros usos incompatíveis com a manutenção de sua qualidade e quantidade, existentes em diagnósticos realizados, no intuito de avaliar as distorções na valoração econômica dos danos ambientais.

Para valoração desses impactos foi adotada a metodologia da produtividade marginal, onde o papel do recurso ambiental no processo produtivo é representado por uma função dose-resposta, que relaciona o nível de provisão do recurso ambiental (água bruta) ao de produção respectiva do produto no mercado (água tratada). A aplicação desta função permite a mensuração do impacto no sistema produtivo, dada uma variação marginal na provisão do bem ou serviço ambiental, e a partir desta variação, pode - se estimar o valor econômico de uso do recurso ambiental. 


\begin{abstract}
This paper presents the analysis of the results obtained by means of bibliographic research on the use of water resources in the Guarapiranga River Basin in the metropolitan region of São Paulo, whose use is the priority Utilities. It identifies the impacts caused by the occupation both disorderly, as the overlapping of the other uses incompatible with the maintenance of their quality and quantity, existing in diagnoses made, in order to assess the distortions in the economic valuation of environmental damage.

For valuation of these impacts was adopted the methodology of marginal productivity, where the role of the environmental resource in the production process is represented by a dose-response function, which relates the level of provision of the environmental resource (water gross) to the production of their product on the market (treated water). The application of this function allows the measurement of impact on the production system, given a marginal variation in the provision of environmental goods or services, and from this change, one can estimate the economic value of resource usage environment.
\end{abstract}




\section{SUMÁRIO}

1. INTRODUÇÃO

2. OBJETIVO

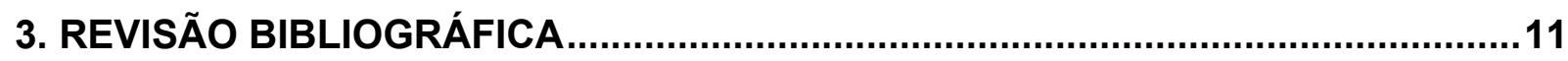

4. ECONOMIA DO MEIO AMBIENTE E VALORAÇÃO ECONÔMICA ..........................28

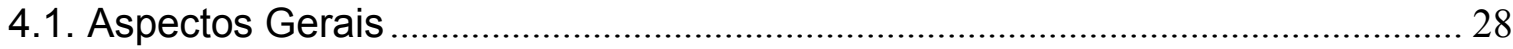

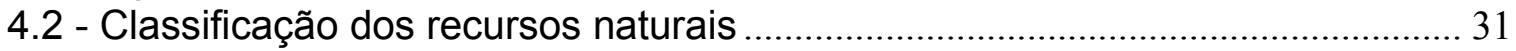

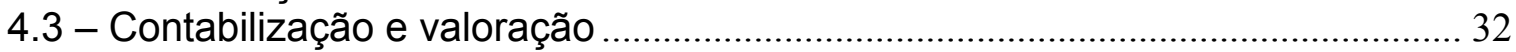

4.4 - Valor econômico de um recurso ambiental - (VERA) .......................................... 35

4.5 - Classificação dos Métodos de Valoração Econômica Ambiental ........................38

5. ANÁLISE DOS PARÂMETROS DE QUALIDADE DA ÁGUA COMO INSTRUMENTO DE VALORAÇÃO

5.1. Parâmetros de qualidade da água ....................................................................... 57

5.2. Utilização dos parâmetros para elaboração dos Índices de Qualidade das

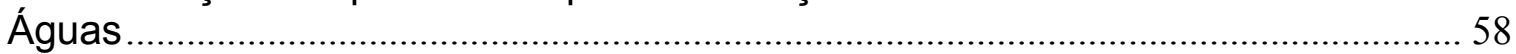

6. ESTUDO DE CASO - BACIA DO GUARAPIRANGA ……..................................

6.1. Histórico de formação da Represa do Guarapiranga............................................ 78

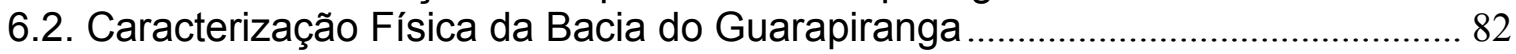

6.3. Caracterização Geral de Uso e Ocupação da Bacia. .............................................. 87

6.4 Caracterização dos Índices de Qualidade das Águas na Guarapiranga ..............994

6.5. Análise entre Evolução do Uso do Solo e Qualidade da Água ............................. 107

7. METODOLOGIA …….........................................................................114

7.1 Elaboração da função física dos impactos, relacionando a dose de poluição à resposta do recurso hídrico degradado na produção para abastecimento público.

7.2 Formulação do Modelo Econômico que mensure o impacto financeiro na produção de Água para Abastecimento Público. ....................................................... 123

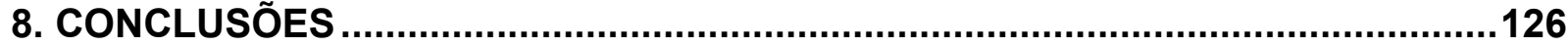

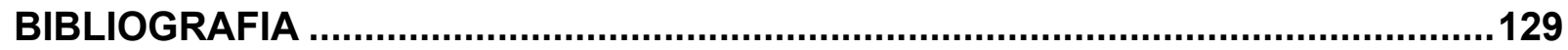

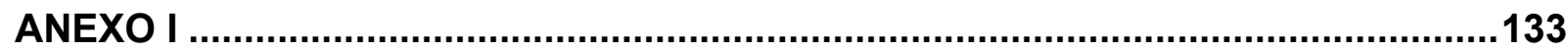




\section{INTRODUÇÃO}

O capitulo 2 apresenta o objetivo deste trabalho em uma área de manancial que sofre a pressão da permanência de uma população local, associada a dependência do sistema metropolitano, em relação ao uso da água produzida por esta área. A escolha deste manancial se deve por ser uma área de grande interesse para a região metropolitana e, portanto, já existirem intervenções de ação governamental com políticas públicas que envolvem prestação de serviço à sociedade. O intuito é um desenvolvimento científico que permita um aprimoramento dessa prestação de serviço em cada nova exigência da sociedade.

O capítulo 3 apresenta as diversas medidas técnicas, institucionais e o extenso aparato legal existente na tentativa de preservação e recuperação do meio ambiente e, em especial dos recursos hídricos indispensáveis à existência humana. Além disso, mostra a necessidade de se associar, a todo este amplo conjunto de medidas, um valor econômico para os impactos causados na degradação do recurso ambiental, que é conseqüência do uso desordenado.

O capítulo 4 mostra a existência de uma economia ambiental preocupada com esses aspectos e apresenta os conceitos e as várias metodologias da ciência econômica existentes para valoração do meio ambiente. É dada ênfase ao Método de Produtividade Marginal, que será aplicado em estudo de caso da Bacia do Guarapiranga, em que se utiliza o recurso ambiental como insumo na produção de água para abastecimento público.

No capítulo 5 são apresentados os diversos parâmetros utilizados como indicadores de qualidade das águas, que são monitorados pela CETESB, responsável pelo controle da qualidade das águas superficiais e pela Sabesp que é responsável pelo controle, tratamento e abastecimento público. Também estão indicadas quais são as análises 
dos respectivos indicadores e suas ponderações com definição do estado da água que são realizadas.

No capítulo 6 está caracterizada a Bacia do Guarapiranga, região que corresponde ao estudo de caso, com as informações sobre a expansão urbana e o levantamento dos dados obtidos nos relatórios da CETESB e Sabesp sobre os parâmetros e respectivos índices de qualidade da água, para um determinado período.

No capítulo 7, define apenas a forma de aplicação desta metodologia de produtividade marginal para valoração do recurso ambiental, devido ao fato da indisponibilidade de dados econômico - financeiros para os parâmetros utilizados. 


\section{OBJETIVO}

O objetivo deste trabalho é definir um modelo de procedimentos para a elaboração de uma metodologia de valor econômico para os impactos ambientais decorrentes associados ao uso e ocupação.

Este estudo é uma proposta no intuito de minimizar os impactos de uma ocupação urbana existente em área de manancial, que a lei de preservação de manancial não tem força para evitar. Está focado nos impactos sobre a qualidade da água causados pela falta de infra-estrutura de saneamento, abordando o uso dos recursos hídricos na Bacia do Guarapiranga, que é de interesse local e também externo, pois milhões de pessoas na Região Metropolitana de São Paulo dependem dela.

A perspectiva é um desenvolvimento científico que permita um aprimoramento da prestação do serviço do uso da água desse manancial, em especial para abastecimento público, buscando a necessidade de melhoria da condição de vida em cada nova exigência da sociedade. 


\section{REVISÃO BIBLIOGRÁFICA}

Entre os problemas atualmente existentes na área da preservação do meio ambiente, para um desenvolvimento sustentável, o estudo dos mananciais tem sido preocupação de diversos órgãos ambientalistas e governamentais.

A legislação sobre o assunto é ampla e abrangente, servindo como um importante instrumento para o direcionamento de medidas para proteção e recuperação de bacias hidrográficas.

Uma das referências para qualquer estudo sobre bacias hidrográficas no estado de São Paulo é a Lei Estadual $N^{\circ} 9866^{1}$, de 28 de novembro de 1997, que dispõe sobre Diretrizes e Normas para a Proteção e Recuperação das bacias hidrográficas dos mananciais de interesse regional.

No nível federal ressalta-se a Lei $9.433^{2}$, de 08 de janeiro de 1997, sobre a Política e o Sistema Nacional de Recursos Hídricos (análoga à Lei Estadual 7.663/91 ${ }^{3}$ ) e a Lei $6.938^{4}$, de $31 / 8 / 81$, que estabelece a política de meio ambiente e cria o Sistema Nacional de Meio Ambiente. Essa política de meio ambiente, tem como objetivo a preservação, melhoria e recuperação da qualidade ambiental propícia à vida, visando

\footnotetext{
${ }^{1}$ Lei Geral Estadual 9.866/97 - Lei de Proteção das Bacias Hidrográficas dos Mananciais de Interesse Regional do Estado de São Paulo dispõe sobre diretrizes e normas para a recuperação das bacias hidrográficas dos mananciais de interesse regional do Estado de São Paulo e dá outras providências.

${ }^{2}$ Lei Federal 9.433/97 instituiu a Política Nacional de Recursos Hídricos, análoga à Lei Estadual 7.663/91.

${ }^{3}$ Lei Estadual 7.663/91 estabelece normas de orientação à Política Estadual de Recursos Hídricos, bem como ao Sistema Integrado de Gerenciamento de Recursos Hídricos - SIGRH, adotando as bacias hidrográficas como Unidades de Gerenciamento de Recursos Hídricos - UGRHI, estabelecendo um sistema de gestão descentralizado e participativo e a obrigatoriedade de realização de Planos de Bacias visando à articulação das ações e à maximização de recursos financeiros no setor hídrico.

${ }^{4}$ Lei Federal 6.938/81 estabelece a Política Nacional de Meio Ambiente e cria o Sistema Nacional de Meio Ambiente.
} 
assegurar, no País, condições para o desenvolvimento socioeconômico, os interesses da segurança nacional e a proteção da dignidade da vida humana.

Na aplicação da legislação em São Paulo, a Secretaria do Meio Ambiente (1997) caracteriza cada uma das unidades de gerenciamento de recursos hídricos (UGRHIs), tanto no que diz respeito aos aspectos físico e ambiental, como com relação à organização dos respectivos comitês de bacias hidrográficas ( $\mathrm{CBHs}$ ), adotando a sistemática de apresentar mapas sintéticos com características das UGRHIs e fichas técnicas com dados referentes à composição dos $\mathrm{CBHs}$, e numéricos, relativos à qualidade e disponibilidade dos recursos hídricos.

As Leis $898^{5}$, de 18 de dezembro de 1.975 , e $1172^{6}$, de 17 de novembro de 1.976, delimitaram áreas de proteção aos mananciais correspondentes a 54\% do território de Região Metropolitana da Grande São Paulo e estabeleceram parâmetros de uso e ocupação do solo para estas áreas, objetivando evitar o adensamento populacional e a poluição das águas, através da orientação da ocupação das bacias hidrográficas dos mananciais de abastecimento da RMSP.

O controle do uso do solo é essencial para evitar o adensamento populacional e seus efeitos na poluição das águas. Para esse controle a legislação criou duas categorias de áreas de proteção, para as quais estabeleceu parâmetros urbanísticos, relacionou os usos permitidos e os critérios para a implantação dos sistemas públicos de abastecimento de água, coleta e disposição de resíduos sólidos e de esgotos.

As áreas de primeira categoria, ou de maior restrição de uso, são aquelas situadas às margens das represas, dos rios e córregos, as áreas cobertas por matas, as áreas inundáveis próximas às represas e cursos d' água e as áreas de grande declividade.

\footnotetext{
${ }^{5}$ Lei Estadual 898/75 disciplina o uso do solo para a proteção dos mananciais, cursos e reservatórios de água e demais recursos hídricos de interesse da Região Metropolitana da Grande São Paulo, e dá providências correlatas, alterada pela lei 3.286/82.

${ }^{6}$ Lei Estadual 1.172/76 delimita as áreas de proteção relativa aos mananciais, cursos e reservatórios de água a que se refere o artigo $2^{\circ}$ da lei $898 / 75$, e estabelece normas de restrição de uso do solo em tais áreas e dá providências correlatas.
} 
Segundo Moreira (1998), a política pública de proteção dos mananciais impede o uso urbano, pois obriga seus proprietários a preservar a vegetação existente nessas áreas, sem qualquer utilidade para eles, apesar das bonificações pela preservação. Como resultado, ocorre a desocupação dessas áreas de primeira categoria, expondo-as às invasões, bem como a destruição das matas.

As áreas de segunda categoria correspondem ao restante das sub-bacias, dividem-se em:

Classe A, que é caracterizada por área urbana com densidade superior a 30 hab/ha e máxima permitida de 50 hab./ha. A política pública de proteção dos mananciais estabelece restrições urbanísticas compatíveis com os padrões da periferia. O efeito foi uma ocupação dessas áreas em padrões compatíveis com a legislação de proteção dos mananciais.

Classe B, situada no entorno daquelas consideradas urbanas e as destinadas à expansão urbana, é caracterizada por densidade de ocupação que varia entre 25 hab./ha e 34 hab./ha.

Como essa legislação não conseguiu impedir a ocupação desordenada e a conseqüente deterioração da qualidade dos mananciais, passou a ser reformulada e, tornou-se necessário preservar e recuperar os mananciais essenciais ao abastecimento público, através de novos instrumentos legais.

Foi necessário compatibilizar as ações voltadas à preservação dos mananciais e a proteção ao meio ambiente, com o uso e a ocupação do solo e o desenvolvimento socioeconômico das regiões protegidas. Isso, através da implementação de uma gestão participativa, que promova a integração entre os diferentes setores governamentais e a participação de agentes da sociedade civil envolvidos na gestão das ações relativas ao saneamento, aproveitamento dos recursos naturais e o desenvolvimento regional, o que torna necessária uma descentralização do planejamento e da gestão das bacias hidrográficas. 
Para isso, a Lei Estadual 9.866/97, de Recuperação e Proteção dos Mananciais induz aos usos compatíveis, a partir de um processo de gestão participativo e descentralizado, e associa um conjunto de instrumentos capazes de reorganizar as áreas protegidas.

Para Moreira (1998), essa Lei supera o controle normativo da legislação anterior, relativa à proteção dos mananciais, as leis 898/75, 1.172/76, 2.177/77 e 3.286/82, as quais trataram por igual todas sub-bacias da Região Metropolitana de São Paulo, não protegeram suficientemente os mananciais, nem controlaram efetivamente a ocupação humana de suas vertentes tributárias.

Porém, a legislação manteve as disposições das leis 898/75 e 1.172/76, preservando a política pública anterior de proteção dos mananciais metropolitanos de São Paulo, alterando apenas as penalidades previstas na lei 898/75.

A Lei Estadual 9.866/97 estabelece preceitos que norteiam a implantação do sistema, a disposição e o tratamento de resíduos sólidos e efluentes líquidos, a penalidade às infrações a ela e às Leis Específicas (12.233/2.006 para a Guarapiranga) e a forma de Gestão. As Leis Específicas devem estabelecer as diretrizes para o controle das situações locais.

Alguns elementos contidos na legislação:

a) A vinculação ao Sistema Estadual de Recursos Hídricos

A política de Proteção e Recuperação das Bacias Hidrográficas dos Mananciais de Interesse Regional do Estado de São Paulo (9.866/97) reforça os princípios estabelecidos pela Lei Estadual 7.663/91 e pela Lei Federal 9.433/97 e especifica as diretrizes gerais para as áreas de proteção e recuperação dos mananciais, garantindo o equacionamento das questões afetas ao tema, em todo o território do Estado de São Paulo. 
b) A adoção da Bacia Hidrográfica como unidade de planejamento e gestão prevista pela Lei Estadual 7.663/91 e pela Lei Federal 9.433/97.

A bacia hidrográfica do Alto Tietê está dividida, para efeito de gerenciamento, em cinco regiões:

1 - Sub-Região Juqueri - Cantareira

2 - Sub-Região Alto Tietê - Cabeceiras

3 - Sub-Região Cotia - Guarapiranga

4 - Sub-Região Billings - Tamanduateí

5 - Sub-Região Pinheiros - Pirapora

Para cada sub-bacia são considerados os processos de ocupação e as peculiaridades ambientais a que estão sujeitas, porém, o controle é sobre o conjunto dos mananciais de interesse regional.

As áreas Cotia/Guarapiranga e Billings/Tamanduateí são as que sofrem maior ameaça em suas águas, em decorrência do intenso processo de loteamentos e ocupações irregulares, com isso, são consideradas prioritárias pela política de recuperação e proteção de mananciais, sendo que, já existe a regulamentação da Lei Específica 12.233 de 2.006 para a Guarapiranga.

c) Áreas de Proteção e Recuperação dos Mananciais - APRMs (Lei 9.866/97).

Considera uma ou mais sub-bacias hidrográficas dos mananciais de interesse regional como unidade de planejamento e gestão. Estas unidades, chamadas de APRM - Área de Proteção e Recuperação dos Mananciais, estão inseridas nas Unidades de Gerenciamento de Recursos Hídricos - UGRHI, previstas pelo Sistema Integrado de Gerenciamento de Recursos Hídricos - SIGRH.

d) Áreas de Intervenção

Delimitadas as APRMs, as leis específicas (12.233/2.006 para a Guarapiranga) criam as Áreas de Intervenção e determinam as diretrizes de uso e ocupação para cada uma destas áreas. 
Essas áreas de Intervenção (Lei 9.866/97) são classificadas em:

1 - Área de Restrição à Ocupação - são aquelas de interesse para a proteção dos mananciais e a preservação, conservação e recuperação dos recursos naturais, além das definidas pela Constituição do Estado.

2 - Área de Ocupação Dirigida - são aquelas de interesse para a consolidação ou a implantação de usos rurais ou urbanos, desde que atendidos os requisitos que garantam a manutenção das condições ambientais necessárias à produção de água em quantidade e qualidade desejáveis para o abastecimento das populações atuais e futuras.

3 - Área de Recuperação Ambiental - são aquelas onde os usos e as ocupações estão comprometendo a quantidade e a qualidade dos mananciais, exigindo ações de caráter corretivo das condições ambientais.

e) Instrumentos de Planejamento e Gestão.

1 - Áreas de Intervenção nas quais são aplicados os dispositivos normativos, de proteção, recuperação e preservação dos mananciais, consideradas suas especificidades e funções ambientais.

2 - Leis Específicas para cada APRM que dão diretrizes e normas direcionadoras do uso e ocupação do solo e parâmetros ambientais garantidores dos padrões de qualidade e quantidade de água.

3 - PDPA - Plano de Desenvolvimento e Proteção Ambiental, que enfoca as políticas públicas e os programas ambientais a serem incorporados pelos Planos de Bacias Hidrográficas.

4 - Suporte Financeiro para garantir meios para a implementação de ações necessárias à proteção dos mananciais.

5 - Controle e Monitoramento da Qualidade Ambiental realizado através do licenciamento e da fiscalização a cargo do Estado ou delegado aos Municípios.

6 - Sistema Gerencial de Informações que consiste em um banco de dados implantado em cada uma das APRMs. 
7 - Classificação das Infrações e gradação das penalidades à Lei Estadual 9.866/97, às Leis Específicas, bem como às Leis 898/75, e 1172/76.

8 - Normatização sobre a Implantação de Infra-estrutura sanitária, especialmente sobre resíduos sólidos e efluentes líquidos.

f) Sistema de Gestão das APRMs

Adota os princípios da gestão descentralizada e tripartite - Estado, Município e Sociedade Civil, contando com:

1 - Órgão Colegiado: Consultivo e Deliberativo, CBH ou Subcomitê, Gestão Tripartite.

- recomenda diretrizes para as políticas setoriais, promovendo a integração e otimização das ações;

- aprova propostas anuais e plurianuais de investimento;

- aprova previamente a criação das Áreas de intervenção, respectivas normas e o PDPA.

2 - Órgão Técnico: Agência de Bacia ou na sua ausência, órgão indicado pelo Órgão Colegiado.

- implanta e operacionaliza o Sistema Gerencial de Informações;

- promove assistência e capacitação técnica e operacional a órgãos, entidades e municípios participantes do Sistema de Gestão;

- elabora, revê, e atualiza o PDPA;

- elabora proposta de criação das Áreas de Intervenção e respectivas normas.

3 - Órgãos da Administração Pública: Responsáveis pelo controle e implementação de políticas.

- promove a fiscalização integrada;

- implementa programas e ações setoriais definidas pelo PDPA;

- licencia, fiscaliza e monitora o uso e ocupação do solo nas APRMs.

Torna-se evidente que, para o gerenciamento de recursos hídricos (lei 9.433/97), é necessária a integração da gestão de recursos hídricos com a gestão ambiental e a do uso do solo. (Muñoz, 2000). 
No Brasil, a Lei Federal 9.985/2000 instituiu o Sistema Nacional de Unidades de Conservação da Natureza - SNUC, e estabeleceu critérios e normas para a criação, implantação e gestão das unidades de conservação, priorizando o uso sustentável dos recursos naturais, e garantindo que a exploração do meio ambiente não afete a perenidade dos recursos ambientais renováveis e dos processos ecológicos, mantendo a biodiversidade e os demais atributos ecológicos, de forma socialmente justa e economicamente viável.

Também, para o Estado de São Paulo, o Decreto Estadual № 48.149, de 9 de outubro de 2003, dispõe sobre a criação e funcionamento dos Conselhos Gestores das Áreas de Proteção Ambiental - APAs.

O Ministério do Meio Ambiente (MMA - 2001) apresenta ações da área ambiental brasileira sob o título de Agendas Ambientais. A agenda Institucional descreve o aparelhamento do Estado brasileiro em termos de legislação, de organismos e arranjos administrativos, de instrumentos legalmente instituídos; enfim, de capacidade instalada para o adequado gerenciamento da problemática ambiental. A agenda de Integração apresenta os programas e projetos mais importantes, de natureza integrada, implementados ou em implementação pela área governamental de meio ambiente, com ênfase nas ações levadas a cabo a partir de 1992, ano em que se consagrou a noção de desenvolvimento sustentável e o Brasil firmou a Agenda 21. As agendas verde, azul e marrom tratam, respectivamente, das novas políticas nacionais de florestas e biodiversidade, de recursos hídricos e de qualidade ambiental em assentamentos humanos, registrando os esforços que estão sendo realizados para implantar e operar de forma eficaz cada uma delas.

A avaliação dos avanços (MMA - 2002) ocorridos nos dez anos que se seguiram à Conferência das Nações Unidas sobre Meio Ambiente e Desenvolvimento Humano (ECO-92), no contexto da evolução legal e institucional da Política Nacional de Recursos Hídricos, bem como as ações realizadas nos principais setores usuários da água, relacionam a pressão que a atividade humana exerce sobre o meio ambiente, 
modificando a qualidade e a quantidade dos recursos naturais e a resposta da sociedade com as medidas de políticas de meio ambiente, econômicas e setoriais.

Esta pressão vem, exaustivamente, sendo analisada em diversos trabalhos e em diferentes áreas de mananciais de grande importância para um futuro sustentável.

Como no modelo GEO Cidades (SVMA-PMSP/IPT, 2004), que se fundamenta na aplicação da estrutura de análise ambiental denominada Matriz PEIR - Pressão, Estado, Impacto, Resposta - propicia a compreensão dos problemas e fenômenos urbano-ambientais por meio da identificação e caracterização de indicadores ambientais e suas relações com os diferentes recursos ambientais envolvidos.

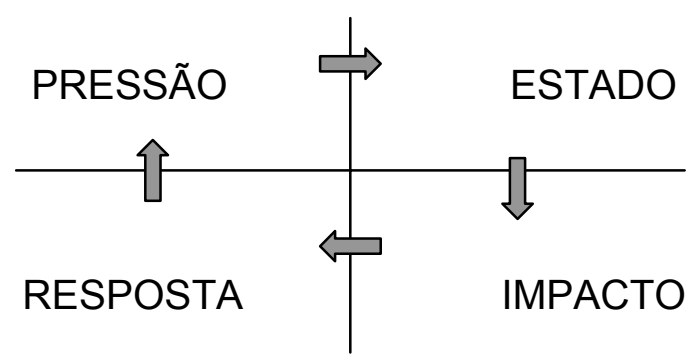

Figura 1 - Ciclo do modelo de abordagem PEIR

Os elementos que caracterizam a PRESSÃO sobre o meio ambiente se relacionam às atividades humanas e sua dinâmica, ou seja, as causas dos problemas ambientais; os de ESTADO dizem respeito às condições do ambiente que resultam dessas atividades. Os indicadores de IMPACTO se referem aos efeitos adversos à qualidade de vida, aos ecossistemas e a sócio-economia local e, os de RESPOSTA revelam as ações da sociedade no sentido de melhorar o estado do meio ambiente, bem como prevenir, mitigar e corrigir os impactos ambientais negativos decorrentes daquelas atividades.

Fundamentando uma gestão ativa na área da bacia do Guarapiranga, o principal trabalho realizado é o Plano de Desenvolvimento e Proteção Ambiental da Bacia do Guarapiranga PDPA (1997) que é um estudo amplo e de natureza multidisciplinar, cuja finalidade é diagnosticar a ocupação urbana e não-urbana da área; seus impactos 
sobre o meio ambiente e os recursos hídricos; a indicação de medidas de recuperação e proteção ambiental; sugestão de estratégias de planejamento e providências para revitalização urbana e a proposição de um novo modelo de gestão.

Complementando, também foi aprovada, no início de 2006, ano do centenário da Guarapiranga, a Lei Específica da bacia (12.233/2006), que define a Área de Recuperação e Proteção aos Mananciais da Bacia Hidrográfica do Cotia/Guarapiranga e estabelece as normas de sua aplicação nos termos da Lei Estadual n. 9.866/97, com o objetivo de proteger e recuperar a região para reverter o processo de degradação e garantir o uso do manancial para abastecimento público.

Porém, tanto a Lei Específica da Guarapiranga (12.233/2.006) como as demais leis para outros mananciais, dependem de conscientização de todos os envolvidos e de uma política efetiva de proteção dessas áreas.

Entretanto, como o controle do uso e ocupação do solo é atribuição exclusiva do município, mesmo com tanto aparato legal, a situação dos recursos hídricos da Bacia do Alto Tietê apresenta dificuldades de gestão do setor, devido à ausência de mecanismos básicos de decisão integrada e de caráter metropolitano.

Com relação à situação de proteção, recuperação e sustentabilidade dos mananciais da RMSP é recomendável que as ações a serem tomadas sejam analisadas sob um ponto de vista mais amplo, que contemple as conseqüências sobre a bacia hidrográfica como um todo, para que sejam efetivas ações de gestão.

Como experiência, temos o Seminário Billings (2002), onde ocorreu um processo de discussão e proposição de ações de recuperação e preservação da bacia hidrográfica, visando sua utilização para abastecimento público. Os resultados apontaram como principal ameaça, a expansão desordenada da ocupação urbana. As recomendações compreendem a implantação e ampliação das áreas protegidas; novo modelo de gestão, recuperação, manejo e operação do reservatório; estratégia de integração de 
políticas públicas para a gestão da bacia; desenvolvimento de alternativas econômicas compatíveis com a produção de água; fiscalização e monitoramento permanente do território; entre outras.

O Programa de Saneamento Ambiental dos Mananciais do Alto Tietê é, em parte, continuação do Programa da Bacia do Guarapiranga para desenvolver ações na bacia do reservatório Billings e nos demais mananciais que abastecem a Região Metropolitana de São Paulo.

O sistema de gestão de recursos hídricos, interpretado por Del Prette (2000), na solução dos problemas relativos ao uso da água, em um ambiente tão complexo quanto ao da área urbanizada da metrópole paulistana, mostra a ocorrência de conflitos de uso, recomendando avaliar os instrumentos utilizados para a gestão.

Como conclui Porto (2003), os sistemas produtores de abastecimento público de água potável, atualmente em operação na Região Metropolitana de São Paulo, conseguirão sustentar a demanda por mais alguns anos, isso se providências imediatas forem tomadas para sua proteção, principalmente naqueles que são mais próximos da região urbanizada da bacia. A sua preservação, visando manter a possibilidade de utilização plena, é essencial para a sustentabilidade do abastecimento público da Região Metropolitana de São Paulo.

Os principais vetores, as causas, os efeitos, bem como a seleção dos principais atores institucionais da fase executiva das propostas de planejamento, podem ser identificados através dos principais problemas relacionados com o uso e a apropriação dos recursos naturais, através da caracterização física, biótica, sócio-econômica, histórica e cultural da área de Proteção Ambiental. (Mori, 1998).

Com o mapeamento da cidade é possível a detecção das regiões mais críticas ao crescimento urbano e o seu direcionamento para regiões mais adequadas. Conforme 
Iwai (2003), as imagens de satélite são bons instrumentos no auxílio ao planejamento urbano da cidade.

Para os diferentes tipos de zoneamento e de seu emprego no Brasil, Chaves (2000), propõe uma moldura para análise dos seus possíveis impactos, enfatizando os aspectos econômicos, enquanto possíveis determinantes da eficácia deste instrumento.

Ensinas (2004) recomenda o estabelecimento de mecanismos financeiros como instrumentos de incentivo à participação dos organismos representativos dos municípios no gerenciamento das bacias, sem os quais, todo arcabouço jurídico vigente, ou a ser criado por meio de Leis específicas, persistirá insuficiente à proteção aos impactos sócio-ambientais de degradação dos mananciais da Região Metropolitana de São Paulo - RMSP, decorrentes do processo de urbanização não planejado.

Algumas razões da rápida ocupação desses territórios são evidenciadas pela evolução do preço de mercado dos imóveis, caracterizada por uma desvalorização generalizada e com um processo de exclusão social que se manifesta sob forma de segregação territorial, que caracteriza a Região Metropolitana de São Paulo. (Venturi, 2001).

Kamogawa (2003), afirma que o nível de degradação dos recursos naturais e ambientais e sua relação com o nível de crescimento econômico de uma nação são de grande importância pelos aspectos de impactos negativos, que levam a uma deterioração irreversível das reservas destes recursos, prejudicando o desempenho e a prosperidade das economias.

A Economia Ecológica, por sua vez, constitui uma abordagem que procura compreender a economia e sua interação com o ambiente, a partir da análise dos princípios físicos e ecológicos, além dos aspectos políticos e sociais, em meio ao qual o processo econômico se desenvolve. 
Todos que tomam decisões econômicas dependem de sinais do mercado para se orientarem. Por isso, constantemente, barateiam os produtos e serviços ao deixarem de incorporar seus custos ambientais de fornecimento.

As decisões sobre projetos envolvendo as águas da cidade irão envolver aspectos de ordem social, política, econômica e ambiental.

Portanto, devemos defender o princípio de que não temos alternativas senão reestruturar a economia, se é que desejamos que o progresso econômico continue nas décadas futuras. Isso baseado em uma estrutura geral da eco-economia, com estratégias para atingir este objetivo no tempo que ainda temos disponível. (Brown, 2003).

Com base na literatura existente, verifica-se que apesar da grande preocupação com a qualidade e quantidade de recursos naturais, onde vários estudos são desenvolvidos para a avaliação dos impactos ambientais decorrentes, com todo o arcabouço legal já instituído para proteção do meio ambiente, principalmente os que afetam o recurso hídrico, em especial na bacia Hidrográfica do Guarapiranga, faltam estudos sobre sua valoração econômica, no aspecto de preservação e correção para utilização presente e futura. Este instrumento poderá representar uma nova visão sobre as estratégias para o desenvolvimento econômico sustentável da região desse manancial.

Conforme descrita pelas Secretarias Municipal do Meio Ambiente e a de Planejamento Urbano da Prefeitura do Município de São Paulo, no Atlas Ambiental, a história da ocupação urbana em São Paulo, além dos determinantes socioeconômicos, encontrase intimamente ligada aos condicionantes naturais de seus terrenos.

A Região Metropolitana de São Paulo - RMSP - possui uma baixa disponibilidade hídrica por habitante, que ocorre devido sua localização estar em uma região de cabeceira de rios, além de ser o maior aglomerado urbano do Brasil, apresentando, hoje, um dos quadros mais críticos do país no que diz respeito à garantia de água em 
quantidade e qualidade para o abastecimento de sua população. A causa está na inexistência eficaz de uma política de ocupação urbana resultando na má gestão do recurso ao longo de sua história, com destaque para a ocupação urbana desordenada das áreas de mananciais mais próximas, como as bacias hidrográficas da Billings e Guarapiranga, e a não conservação das áreas mais distantes, como as represas do Sistema Cantareira.

O crescimento populacional desordenado nas cidades e a industrialização intensa e rápida foram acompanhados por uma intensa degradação ambiental, especialmente a degradação da qualidade da água, nos rios e reservatórios localizados nas áreas de expansão das metrópoles.

Segundo Porto (2003), o abastecimento Público da Região Metropolitana de São Paulo - RMSP - é proporcionado, em sua maior parte (mais de 90\%), por três grandes conjuntos de reservatórios: os mananciais produtores do Sistema Cantareira, do Sistema Guarapiranga-Billings e do Sistema Alto Tietê.

A EMAE - Empresa Metropolitana de Águas e Energia, atualmente é a responsável pela operação do reservatório Guarapiranga, cuja finalidade é a de regularizar a vazão aduzida para a Estação de Tratamento de Água do Alto da Boa Vista (ETA - ABV), em São Paulo, com propósito de abastecimento público.

Em 2000, foi construída e iniciada a operação de um conjunto de duas elevatórias, situadas em um braço do reservatório Billings, denominado Taquacetuba, que permitiu a transferência de $2 \mathrm{~m} 3 / \mathrm{s}$ para o reservatório Guarapiranga. Em função da estiagem severa de 2000, há uma licença especial da Secretaria do Meio Ambiente do Governo do Estado de São Paulo para que, em casos de emergência, possa ser transferida uma vazão de até $4 \mathrm{~m} 3 / \mathrm{s}$. 
Existe ainda a possibilidade, a partir do aproveitamento do Alto e Médio Capivari e do Juquiá, de virem a ser veiculadas pela Guarapiranga vazões muito maiores, superiores a $30 \mathrm{~m} 3 / \mathrm{s}$.

Portanto, percebe-se o desafio de abastecer com água potável os 18 milhões de habitantes, sob a forte pressão da urbanização, a qual gera profundo impacto sobre a proteção dos mananciais e a qualidade da água.

Existe um grande conflito entre a preservação dos mananciais e a gestão territorial, o que é um desafio para o setor de recursos hídricos, pois depende da integração da gestão da água com a gestão do território.

O problema se agrava com a insuficiência de investimentos em infra-estrutura social e com a falta de ordenação do uso do solo: o não atendimento da demanda de serviços básicos da população associado à pobreza e à falta de condições sócio-econômicas de grande parcela da população gera um processo de ocupação irregular do solo, cuja lógica é incompatível com a proteção ambiental e que vem degradar ainda mais o meio ambiente.

Para Kamogawa (2003) surge um processo cíclico, onde a oferta de recursos naturais e a qualidade ambiental determinam o processo de crescimento econômico, gerando uma série de pressões negativas sobre o meio ambiente que por sua vez influencia o nível de crescimento econômico.

Em sua análise de crescimento econômico, uso dos recursos naturais e degradação ambiental, Kamogawa (2003), no caso da qualidade da água, utilizou os indicadores de quantidade de oxigênio dissolvido (OD em $\mathrm{mg} / \mathrm{l}$ ), demanda bioquímica de oxigênio (DBO - 5,20) em mg/l, a quantidade de coliformes fecais (em NMP/100 ml) e o índice de qualidade das águas (IQA/CETESB) para a bacia do alto Tietê. Esses indicadores absolutos de qualidade estão sujeitos à influência de variáveis externas como a capacidade de absorção do ambiente e à concentração populacional. 
Para explicar a relação entre crescimento econômico e degradação ambiental, foram utilizadas como variáveis explanatórias o PIB per capita, a variável temporal T, variáveis "dummy" para captar efeitos externos e a população residente para subtrair os efeitos do crescimento populacional na qualidade da água.

Para cada um dos indicadores foram obtidos resultados do "nível de renda $\mathrm{x}$ qualidade da água”. Os resultados mostraram que o principal fator abatedor da degradação ambiental das águas é o representado pelas ações externas (dummy).

Portanto, a resposta da renda na degradação ambiental é função da sensibilidade do consumidor em considerar que determinado indicador de qualidade da água é ou não positivo para ele, e não em resposta ao nível de produção.

Logo, é a disposição a pagar.

Portanto, a avaliação econômica do meio ambiente tem como propósito incorporar o custo e o benefício proporcionado pelo meio ambiente, percebendo-se o valor real da escassez do recurso que é necessário para o desenvolvimento econômico e o bem estar das pessoas.

Para o valor econômico associado ao recurso hídrico são os custos e benefícios relacionados aos projetos de preservação, desenvolvimento e investimentos para a melhoria da qualidade da água destinada ao uso abastecimento público.

Também, conforme Borger (1995), entre as causas da degradação ambiental estão distorções em âmbito econômico, decorrentes da não incorporação dos valores ambientais nas decisões econômicas, e certamente, a solução dos problemas ambientais envolve a correção destas e a promoção de incentivos para a conservação do meio ambiente e redução da degradação ambiental. 
Borger (1995) analisou a metodologia da técnica de Avaliação Contingente para a valoração do meio ambiente estimando os benefícios do Programa de Saneamento Ambiental da Bacia do Guarapiranga.

Este estudo visa incorporar valor econômico ao impacto buscando procedimentos que possam definir a metodologia de valoração que seja adequada para essa análise.

Portanto, é necessário conhecer as diversas metodologias de valoração existentes na teoria econômica, assunto apresentado no próximo capítulo. 


\section{ECONOMIA DO MEIO AMBIENTE E VALORAÇÃO ECONÔMICA}

A maioria dos ativos ambientais não tem substituto e a inexistência de sinalização de "preços" para seus serviços distorce a percepção dos agentes econômicos, induzindo os mercados às falhas na sua alocação eficiente e evidenciando uma "divergência entre os custos privados e sociais.", (Marques e Comune 1995, p.633, 634 apud Nogueira et al, 2000). Essa "ausência" de preços para os recursos ambientais, e os serviços por eles prestados, traz um sério problema: uso excessivo dos recursos. Isso pode conduzir a uma criação "espontânea" desses mercados muito tardiamente, quando eles estiverem degradados num nível irreversível, ou à situação de mercados não serem criados nunca, levando à extinção completa do recurso.

\subsection{Aspectos Gerais}

Existem duas categorias de agentes na análise microeconômica que são os consumidores e os produtores.

O consumidor escolhe os bens e serviços conforme preferências e a disponibilidade de recursos, que detém utilidade, é a satisfação obtida pelo consumo de cada cesta de bens. A função utilidade é determinada pelo preço dos bens e pela renda do consumidor.

A disposição a pagar do consumidor, relacionada à quantidade de um bem, define a curva de demanda por bens e serviços que é a função utilidade. Quanto menor o preço maior a quantidade demandada.

As quantidades ofertadas de um bem, relacionadas com os preços pelos quais as empresas estão dispostas a vendê-lo, define a curva de oferta que é a função de produção. Quanto maior o preço maior a quantidade ofertada. 


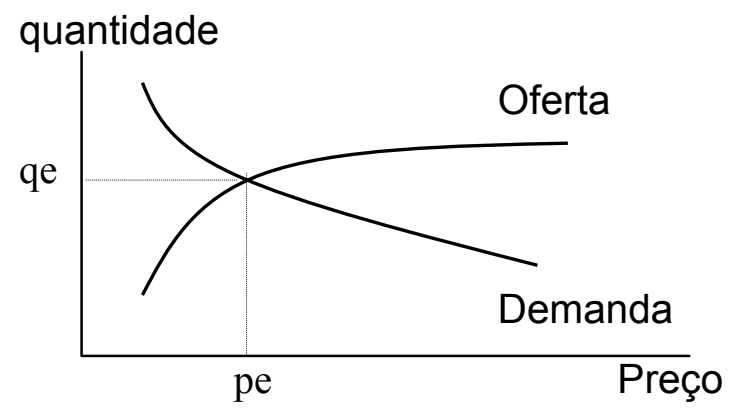

Figura 2 - Curvas de Oferta e Demanda

O modelo de concorrência perfeita, sob condições ideais, está no equilíbrio entre a oferta e a demanda dos bens. Na situação de concorrência perfeita o consumidor escolhe e tem preferência por bens e serviços disponíveis, maximizando o nível de utilidade. O produtor maximiza seu lucro quando o preço dado pelo mercado é igual ao custo marginal (custo de produzir uma unidade adicional). O preço de equilíbrio indica que a quantidade ofertada é igual à consumida, onde consumidores maximizam a utilidade e produtores seus lucros.

\subsubsection{Teoria do Bem-Estar}

O objetivo da economia do bem-estar é estudar as questões relativas à alocação de recursos escassos; a alocação ótima será a que maximizar o bem estar de consumidores e produtores, sujeita às limitações de quantidades disponíveis.

O critério adotado para o bem-estar é o Ótimo de Pareto, que caracteriza um estado no qual não é possível melhorar a situação de uns sem deteriorar a situação de outros. $O$ preço de equilíbrio do mercado de concorrência perfeita representa a situação de eficiência econômica.

\subsubsection{Bens Privados e Públicos}

Os Bens Privados identificam os direitos de propriedade individual e o consumidor através do processo de compra revela suas preferências. Estes bens podem ser transacionados livremente (carro, imóvel, etc.) ou não, como a recreação em parques, bibliotecas públicas, concessão de emissões de rádio e televisão. 
Os Bens Públicos não tem um proprietário identificável, os direitos de propriedade ou acesso são coletivos e os custos de provisão e manutenção são arcados por toda a coletividade através do pagamento de taxas, tarifas, impostos. Exemplos: qualidade do ar e da água, riscos ambientais, estradas, iluminação pública, defesa nacional, conhecimento cientifico.

A avaliação econômica do meio ambiente assume que o fato de não se definir o direito de propriedade para bens e serviços ambientais, não significa que não seja possível identificar as preferências individuais por eles e que não tenham preço. (Borger, 1995).

\subsubsection{Externalidades}

Externalidade é o efeito do consumo ou a produção de um bem ou serviço por um agente econômico e que afeta, involuntariamente, outro agente sem a devida compensação ou remuneração, resultando que o preço de mercado não corresponde ao custo.

A externalidade pode ser um efeito positivo ou negativo. A poluição é considerada uma externalidade negativa, um efeito externo do processo de uso e produção que afeta a comunidade sem a devida compensação; os programas de recuperação e controle ambiental são externalidades positivas. Por exemplo, a poluição despejada em um curso d’água pode ser, para o poluidor, uma solução de baixo custo para a deposição de resíduos. Mas as empresas e os indivíduos a jusante podem sofrer as conseqüências, através de custos mais elevados resultantes das perdas em produção de pescado, custos mais elevados em tratamento da água, redução da oportunidade de recreação ou perda de suprimentos críticos de água potável. Se ao contrário, uma empresa limpar a água poluída de que se abastece, despejando água limpa após usá-la em seu processo interno, estaria criando uma externalidade positiva, gerando um beneficio externo. 
Segundo Borger (1995), para que os custos ou benefícios dessas externalidades sejam considerados nos cálculos do custo econômico, é necessário internalizar os efeitos externos, através da identificação do emissor e do receptor da externalidade, possibilitando, assim, conhecer os custos da poluição e da sua prevenção.

\section{2 - Classificação dos recursos naturais}

Segundo Young et al. (2000), a classificação dos recursos naturais, dada a existência ou não de mercado específico possui a vantagem de associar a diferenciação entre os recursos naturais aos métodos pelos quais estão sendo valorados. Mas também é sujeita a situações de indefinição, pois se pode comercializar o direito de acesso a um recurso, sem que se esteja comercializando o próprio recurso. Por exemplo, pode-se cobrar uma taxa de visita a um parque florestal, mas isso não significa que a floresta esteja sendo comercializada.

Uma das formas de classificação de recursos naturais é de separá-los em duas grandes categorias: recursos exauríveis e recursos de fluxo.

\subsubsection{Recursos exauríveis}

São aqueles cuja exploração pela atividade humana leva necessariamente à redução na sua disponibilidade futura, como é o caso dos recursos minerais e florestais. A disponibilidade futura varia inversamente com o ritmo de exploração dos recursos; logo, o enquadramento de um recurso como exaurível pressupõe a possibilidade de sua escassez futura.

\subsubsection{Recursos de fluxo}

São aqueles que podem ter suas condições originais restauradas pela ação natural ou humana, como o ar e a água. A utilização desses recursos não reduz os seus estoques, ao menos no curto prazo. No entanto, podem ocorrer degradação, contaminação ou outras formas de perda de qualidade que acabam gerando perdas na capacidade produtiva e na qualidade de vida dos indivíduos das comunidades afetadas (externalidades). 
Os recursos de fluxo são geralmente identificados com os recursos renováveis, e os exauríveis são associados aos não- renováveis. Mas existem casos que escapam a essa regra, como nos casos do petróleo, considerado exaurível porque sua formação leva tempo superior a milhares de anos, e das florestas que, apesar de renováveis, podem ser consideradas exauríveis porque não se recuperam caso sejam destruídas as condições ecológicas que garantem sua regeneração natural.

O solo é outro recurso natural de difícil classificação. Por um lado, pode ser classificado como recurso de fluxo porque a sua utilização corrente não impede sua utilização futura.

Porém, o solo possui determinadas características naturais que podem ser permanentemente comprometidas como conseqüência de seu mau uso. Do mesmo modo, as águas superficiais são tratadas como recursos de fluxo, embora as reservas de água potável sejam recursos cada vez mais escassos.

\section{3 - Contabilização e valoração}

A valoração da degradação dos recursos ambientais deve ser separada de acordo com a classificação do recurso, como recurso de fluxo ou recurso exaurível, devido às formas distintas de correção decorrentes da degradação ou esgotamento.

\subsubsection{Recursos de fluxo}

Conforme apresentado por Young et al. (2000), em relação aos recursos de fluxo, três propostas de incorporação nas contas ambientais se destacam; são elas: despesas defensivas, despesas ambientais e benefício ambiental líquido.

\section{a) Despesas Defensivas}

Essa proposta sugere que sejam excluídos da demanda final todos os custos que a economia incorreu a fim de se precaver contra a poluição ou degradação decorrente do uso dos recursos de fluxo. Refere-se aos gastos que são convencionalmente 
classificados como consumo pessoal ou formação de capital, mas que não refletem melhorias nas condições de vida ou de produção da economia. O objetivo é impedir que o conjunto das atividades decorrentes da degradação ambiental, tais como despesas médicas ou instalação de equipamentos antipoluentes, sejam vistos como acréscimos de riqueza à economia.

\section{b) Despesas Ambientais}

O ajuste a partir das despesas ambientais consiste em retirar do produto as despesas que são necessárias para evitar a degradação ou restaurar e substituir os elementos degradados do meio ambiente no período de referência. Refere-se ao montante que a economia deveria dispender para evitar a degradação, mantendo o meio ambiente intacto ou plenamente restaurado (Bartelmus et al. 1991 apud Young et al. 2000). Por serem gastos potenciais que deveriam ter sido realizados, mas que não ocorreram, eles se diferenciam das despesas defensivas, que são gastos efetivos. A valoração das despesas ambientais se dá pela estimativa de gastos que seriam necessários para manter o meio ambiente de volta às suas condições de equilíbrio. Essa estimativa diz respeito ao custo de recuperar os elementos degradados durante um período, baseada em padrões técnicos de tolerância determinados pelas agências de fiscalização ambiental.

\section{c) Benefício Ambiental Líquido}

Considera o uso dos recursos de fluxo através do tratamento dos custos e benefícios sociais, prestados pelo meio ambiente, como agente econômico, cujas transações com os demais agentes são valoradas e consolidadas em uma conta específica (Peskin, 1989 apud Young et al, 2000).

Como as contas dos demais agentes da economia, a conta de meio ambiente é dividida em duas partes:

A crédito são computados os subsídios que o meio ambiente presta a determinados agentes que se beneficiam do uso gratuito dos recursos de fluxo. O montante que deve 
ser gasto pelo usuário em termos de recuperação dos recursos corresponde ao serviço prestado pelo meio ambiente, e que deve ser acrescido ao produto como produção ambiental.

A débito são lançados os custos impostos aos demais agentes econômicos que tiveram vedado o acesso aos recursos devido à sua degradação ocasionada por terceiros, e que são denominadas perdas ambientais. As perdas ambientais, por serem externalidades negativas que acarretam em perdas de bem-estar dos agentes, são subtraídas do produto sob forma de consumo ambiental.

O saldo entre serviços e perdas ambientais representa o benefício líquido da utilização dos recursos naturais, e é incorporado à produção ambiental.

Conforme Young et al. (2000), no caso dos recursos de fluxo, que não dispõem de preços de mercado, deve-se usar técnicas de valoração de forma a mensurar a disposição a pagar ou aceitar pela eliminação das perdas ambientais. Os serviços ambientais são, dessa forma, calculados pela disposição a pagar pelo tratamento do recurso, e as perdas estimadas pela disposição a pagar dos agentes pelo consumo daqueles recursos. Uma taxa de desconto intertemporal deve ser introduzida para o caso da perda ambiental não ocorrer no presente, mas ser esperada no futuro.

A disposição a pagar pode ser melhorada, aumentada ou potencializada pelas pressões de difusão tecnológica e pela conscientização ambiental e social sobre o uso do bem de interesse coletivo.

A fundamentação teórica da análise custo-benefício está na aplicação da teoria neoclássica do bem-estar à utilização dos recursos naturais. O ponto de utilização ótima é determinado igualando-se o serviço ambiental marginal à perda ambiental marginal, ou seja, quando o benefício marginal da utilização do recurso for nulo. 
O Quadro apresentado por Young et al. (2000), sintetiza as propostas de contabilização dos custos ambientais e as respectivas técnicas de valoração dos impactos decorrentes do uso de recursos de fluxo.

\section{Técnica de valoração}

Forma de contabilização dos custos ambientais
a) Gasto efetivo decorrente da mitigação da degradação (Menos) Despesas Defensivas
b) Gasto necessário para evitar a degradação (Menos) Despesas Ambientais
c) Disposição a pagar ou aceitar dos indivíduos pela (Mais) Benefício Ambiental Líquido eliminação da degradação

\subsubsection{Recursos Exauríveis}

Para Young et al. (2000), o problema central dos estudos nessa linha refere- se ao possível esgotamento dos recursos não-renováveis. Eles enfatizam que a opção de explorar e consumir tais recursos no presente leva necessariamente a uma diminuição na capacidade futura de se usufruir os mesmos. Trata- se, portanto, de uma questão de decidir como determinado recurso deve ser aproveitado intertemporalmente, tendo implícita a idéia de que o incremento no ritmo atual de extração leva ao sacrifício das gerações futuras.

\section{4 - Valor econômico de um recurso ambiental - (VERA)}

A literatura econômica convencional sugere que o valor de um bem ou serviço ambiental pode ser mensurado por meio da preferência individual pela preservação, conservação ou utilização desse bem ou serviço (Bateman \& Turner, 1992 apud Nogueira, 2000).

O valor de um recurso ambiental será definido por uma função de seus atributos. Os fluxos de bens e serviços ambientais gerados pelo consumo definem os atributos relacionados ao seu valor de uso, ou seja, refere-se ao uso efetivo ou potencial que o recurso pode prover. Os atributos relacionados à própria existência do recurso, independentemente de uma relação com os seres humanos, sem qualquer associação 
ao seu uso presente ou futuro, configuram o valor de não uso, ou valor intrínseco, ou valor de existência do recurso ambiental.

Componentes do Valor Econômico Total (VET) de um bem ou serviço ambiental:

\section{VET = V uso + V não uso}

O valor de uso (VU) representa o valor atribuído pelas pessoas pelo uso ou usufruto, propriamente dito, dos recursos ambientais. É subdividido em valor de uso direto, valor de uso indireto e valor de opção.

- Valor de Uso Direto - VUD - é o uso propriamente dito, determinado pela contribuição que um recurso faz da produção ou uso corrente. $O$ indivíduo usufrui do recurso através de, por exemplo, extração, visitação ou alguma outra forma de atividade produtiva ou consumo direto.

- Valor de Uso Indireto - VUI - determinado pela contribuição dos serviços funcionais que o meio ambiente provê para suportar a produção e o consumo corrente. O benefício do recurso é derivado de funções ecossistêmicas como, por exemplo, a proteção dos corpos d'água decorrente da preservação das florestas.

- Valor de Opção - VO - refere-se ao valor da disponibilidade do recurso ambiental para uso futuro. Valor estimado por projeções do uso no futuro (baseadas em dados históricos), mais a disposição a pagar das pessoas que não usufruem, atualmente, de serviço prestado pelo meio ambiente, mas atribuem um valor a este para preservar a oportunidade de uso no futuro. Trata-se de um valor relacionado a usos futuros que podem gerar alguma forma de benefício ou satisfação aos indivíduos.

$$
V O=V F+D A P
$$

A DAP envolve incertezas quanto à disponibilidade em relação à demanda do bem no futuro. Portanto, o valor de opção pode ser positivo ou negativo, dependendo das preferências futuras dos indivíduos. 


\section{Valor de não uso (VNU)}

- Valor de Existência - VE - é a disposição a pagar pelo não uso do recurso. Está no fato intrínseco de existir de um recurso, e aparece na satisfação de saber que o recurso existe. Representa um valor atribuído à existência do meio ambiente independentemente do seu uso atual ou futuro. Trata- se do valor conferido pelas pessoas a certos recursos ambientais, como florestas e animais em extinção, mesmo que não tencionem usá-los ou apreciá-los.

Portanto, o valor econômico total seria a soma de todas as parcelas que compõem os valores de uso e não uso:

$$
(\text { VERA })=\text { VET }=\text { VUD + VUI + VO + VNU }
$$

A valoração econômica do meio ambiente passa pelo cálculo do VET para o bem ou serviço ambiental sob análise. Entretanto, como destacam Marques \& Comune (1995) apud Nogueira et al (2000), o valor econômico total do meio ambiente não pode ser integralmente revelado por relações de mercado. Muitos de seus componentes não são comercializados no mercado e os preços dos bens econômicos não refletem o verdadeiro valor da totalidade dos recursos usados na sua produção. 


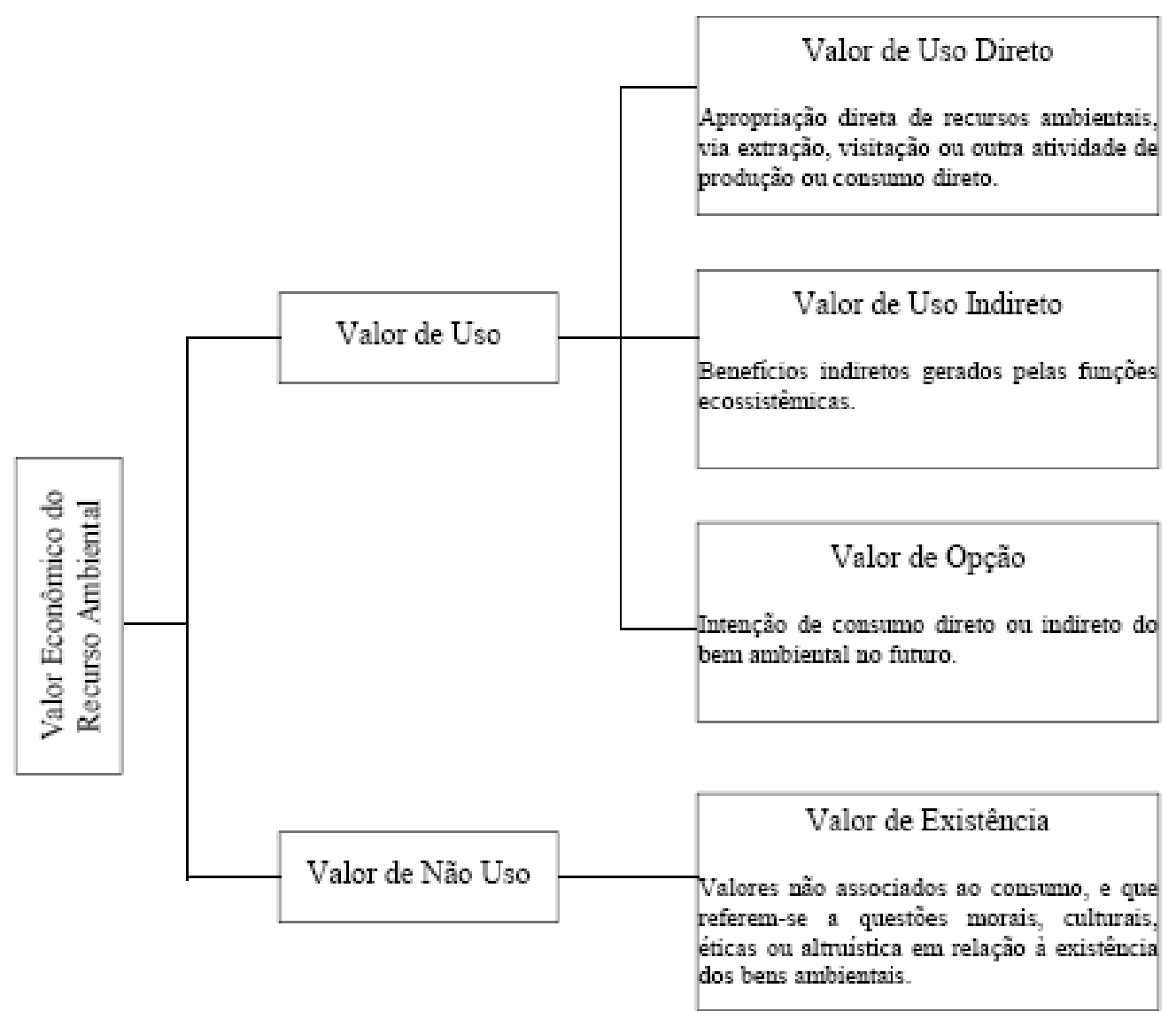

Figura 3 - Decomposição do valor econômico de um recurso ambiental

\section{5 - Classificação dos Métodos de Valoração Econômica Ambiental}

Segundo Nogueira et al (2000), os métodos de valoração econômica ambiental são utilizados para estimar os valores que as pessoas atribuem aos recursos ambientais, com base em suas preferências individuais.

Para Maia (2002), o fato de grande parte dos recursos ambientais serem de natureza pública, de livre acesso às pessoas e sem preço definido no mercado, faz com que muitas vezes sejam condenados a um uso abusivo, inconsciente e descontrolado. Isto permite que os agentes não internalizem em suas obrigações os custos sociais ambientais, possibilitando o surgimento de externalidades negativas para a população. 
Uma política ambiental proposta pela literatura é aquela que cria condições para que os agentes econômicos internalizem os custos da degradação em suas obrigações, e isto pode ser feito através da precificação dos recursos naturais.

Entre várias técnicas desenvolvidas para estimar esses valores as mais recorrentes formas de imputar valor aos recursos ambientais destacam-se:

- técnica da produção sacrificada: mede o dano ambiental a partir da perda de produção por ele causada. Por exemplo, o custo da poluição da água é pelo menos equivalente à perda de recursos pesqueiros decorrentes do vazamento de efluentes em rios, lagoas ou baías.

- técnica do preço da propriedade: através de procedimentos econométricos, mede a perda de valor de ativos ocasionada por degradação da qualidade ambiental. Por exemplo, o custo da poluição sonora ou do ar é pelo menos equivalente à depreciação dos preços de imóveis localizados em área de grande ruído ou poluição atmosférica.

- técnica do custo de viagem: atribui valor a um determinado sítio natural em função dos gastos demonstrados pelos visitantes que se deslocam para apreciar os benefícios turísticos ou de recreação do local. Por exemplo, um parque natural vale pelo menos o montante total de gastos desembolsados pelas pessoas que deslocam para visitá-lo.

- técnica da valoração contingente ou do mercado hipotético: identifica o valor do recurso ambiental ou de alguma propriedade sua através de pesquisas diretas às pessoas para indagar o valor que elas estão dispostas a pagar por esse benefício, ou dispostas a receber para compensar sua perda. Por exemplo, o valor do parque natural poderia ser obtido através de questionários perguntando diretamente quanto os visitantes estariam dispostos a pagar para que essa área permaneça preservada.

Não existe uma classificação universalmente aceita sobre as técnicas de valoração econômica ambiental. Maia (2002), também concorda que não há um padrão universalmente aceito para classificação dos métodos de valoração existentes. Alguns 
procuram obter o valor do recurso diretamente sobre as preferências das pessoas, utilizando-se de mercados hipotéticos ou de bens complementares para obter a disposição a pagar (DAP) dos indivíduos, e podem ser classificados como métodos diretos.

Os métodos diretos de valoração podem ser divididos em outros dois subgrupos. 0 primeiro, representado pelo método de avaliação contingente, simula um mercado hipotético para captar diretamente a disposição a pagar das pessoas para o bem ou serviço ambiental. O segundo, formado pelos métodos de preços hedônicos e custo de viagem, procura obter indiretamente a disposição a pagar dos indivíduos através de um mercado de bens complementares.

Por sua vez, os denominados métodos indiretos procuram obter o valor do recurso através de uma função de produção relacionando o impacto das alterações ambientais a produtos com preços no mercado.

Os resultados de todos estes métodos são expressos em valores monetários, por ser a medida padrão da economia e a forma como os indivíduos expressam suas preferências no mercado.

Cada método de valoração apresenta suas limitações na captação dos diferentes tipos de valores do recurso ambiental. A escolha correta deverá considerar, entre outras coisas, o objetivo da valoração, a eficiência do método para o caso específico e as informações disponíveis para o estudo. No processo de análise devem estar claras as limitações metodológicas, e as conclusões restritas às informações disponíveis. 


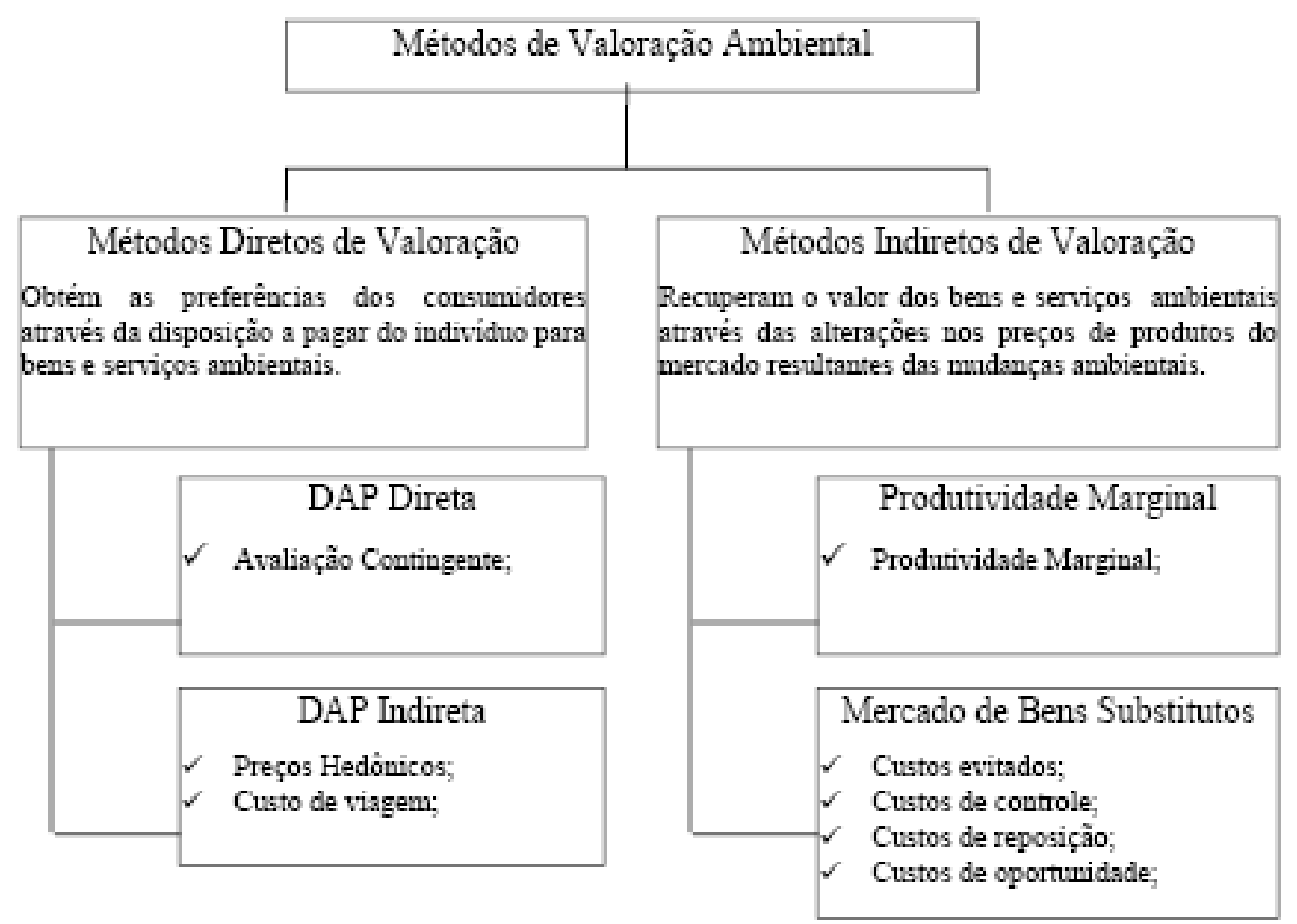

Figura 4 - Classificação dos Métodos de Valoração Ambiental

Diversos são os autores que propõem uma classificação dos métodos de valoração:

Bateman \& Turner (1992, p.123) apud Nogueira et al. (2000), propõem uma classificação dos métodos de valoração econômica distinguindo-os pela utilização ou não das curvas de demanda marshalliana ou hicksiana (Tabela 1). 
Tabela 1. Metodos para valoraçâo monetária do meio ambiente segundo Bateman e Turner (1992, p.123 - adaptaçâo).

\begin{tabular}{|c|c|c|}
\hline Tipo de Abordagem & Tipos de Métodos & Observaçoes \\
\hline $\begin{array}{l}\text { A) Abordagens com } \\
\text { Curva de Demanda }\end{array}$ & $\begin{array}{l}\text { 1) Métodos de Preferéncias Expressas } \\
\text { 1.1) Método de Valoraçăo Contingente (MVC) } \\
\text { 2) Métodos de Preferéncias Reveladas } \\
\text { 2.1) Método de Custos de Viagem (MCV) } \\
\text { 2.2) Método de Preços Hedónicos (MPH) } \\
\text { 3) Método Dose-Resposta (MDR) } \\
\text { 4) Método de Custos de Reposiçào (MCR) } \\
\text { 5) Métodos de Comportamento Mitigatório }{ }^{74} \\
\text { (MCE) }\end{array}$ & $\begin{array}{l}\text { b) Curva de Demanda Não-Compensada } \\
\text { (marshalliana) } \\
\text { - Medida de bem-estar de Excedente do } \\
\text { Consumidor } \\
\text { c) Não se obtèm Curva de Demanda } \\
\text { (apenas estimativas de dose de valor) } \\
\text { - Medidas de bem-estar nào confiáveis }\end{array}$ \\
\hline
\end{tabular}

* Por exemplo, o Metodo de Custos Evitados.

Hufschmidt et al. (1983, p.65-67) apud Nogueira et al. (2000), fazem suas divisões de acordo com o fato de a técnica utilizar preços provenientes:

- de mercados reais;

- de mercados substitutos; ou

- mercados hipotéticos (Tabela 2). 
Tabela 2. Classificaçao das Técnicas de Valoraçao de Custos e Benefícios para avaliar as consequèncias sobre a qualidade ambiental (Hufschmidt et al.,1983, p.66-67).

\begin{tabular}{|c|c|c|}
\hline Preços obtidos a partir de: & Método ou Técnica de Valoraçāo & Equivalente na Tabela 1 \\
\hline \multirow[t]{2}{*}{ Mercados Reais } & $\begin{array}{l}\text { 1) Valoraçào dos Benefícios } \\
\text { 1.1) Mudanças no Valor da Produçāo } \\
\text { 1.2) Perda de Salários/Lucros }\end{array}$ & $\begin{array}{l}\text { 1) Valoraçăo dos Benefícios } \\
\text { 1.1) MDR } \\
\text { 1.2) MCE }\end{array}$ \\
\hline & $\begin{array}{l}\text { 2) Valoração dos Custos } \\
\text { 2.1) Gastos Preventivos } \\
\text { 2.2) Custos de Reposiçăo } \\
\text { 2.3) Projeto Sombra } \\
\text { 2.4) Análise Custo-Eficiència }\end{array}$ & $\begin{array}{l}\text { 2) Valoraçào dos Custos } \\
\text { 2.1) MCE } \\
\text { 2.2) MCR } \\
\text { 2.3) MCR } \\
\text { 2.4) MPM }\end{array}$ \\
\hline Mercados Substitutos & $\begin{array}{l}\text { 3) Valıraçào dos Benefícios } \\
\text { 3.1) Bens de Mercado como Substitutos } \\
\text { 3.2) Abordagem do Valor de Propriedade } \\
\text { 3.3) Outras Abordagens do Valor da Terra } \\
\text { 3.4) Custos de Viagem } \\
\text { 3.5) Abordagem do Diferencial de Salário } \\
\text { 3.6) Aceitação de Compensaçăo }\end{array}$ & $\begin{array}{l}\text { 3) Valoraçào dos Benefícios } \\
\text { 3.1) MPM } \\
\text { 3.2) MPH } \\
\text { 3.3) MPH } \\
\text { 3.4) MCV } \\
\text { 3.5) MPH } \\
\text { 3.6) MVC }\end{array}$ \\
\hline \multirow[t]{2}{*}{ Mercados Hipotéticos } & $\begin{array}{l}\text { 4) Questionamento Direto de Disposição a Pagar } \\
\text { 4.1) Jogos de Leilāo }\end{array}$ & $\begin{array}{l}\text { 4) Questionamento Direto de Disposição a Pagar } \\
\text { 4.1) MVC }\end{array}$ \\
\hline & $\begin{array}{l}\text { 5) Questionamento Direto de Escolha de Quantidade } \\
\text { (para estimar indiretamente a Disposiçăo a Pagar) } \\
\text { 5.1) Método da Escolha Sem Custo }\end{array}$ & $\begin{array}{l}\text { 5) Questionamento Direto de Escoha de Quantidade } \\
\text { (paraestimar indiretamente a Disposiçäo a Pagar) } \\
\text { 5.1) Escolha Sem Custo (Sem equivalente) }\end{array}$ \\
\hline
\end{tabular}

Nessa classificação, as variações na qualidade de um recurso ambiental são mensuradas pelo lado dos benefícios ou dos custos resultantes dessas mesmas variações. É uma avaliação da situação com a mudança no recurso ambiental e sem a mudança.

> Pearce (1993) apud Nogueira et al. (2000), indica que os métodos de valoração têm como um dos objetivos estimar os valores econômicos para os recursos naturais, simulando um mercado hipotético para estes bens sem um preço definido. Para ele, mensurar as preferências dos indivíduos sobre as alterações em seu ambiente, não se trata de transformar um bem ambiental num produto de mercado.

Ele afirma que existem quatro grandes grupos de técnicas de valoração econômica, desenvolvidas a um nível sofisticado (Tabela 3).

O primeiro grupo é formado pelas técnicas que ele chama de "Abordagens de Mercado Convencional" que utilizam os preços de mercado ou preços sombra como 
aproximação, semelhantemente aos métodos dos mercados reais de Hufschmidt et al. (1983). O segundo grupo é chamado de "Funções de Produção Doméstica". O terceiro, os "Métodos de Preços Hedônicos". E o quarto e último grupo são os "Métodos Experimentais".

Tabela 3. Classificaçao dos Metodos de Valoraçao Monetária de acordo com Pearce (1993).

\begin{tabular}{|c|c|c|}
\hline Grupos de Técnicas & Métodos & Equivalente na Tabela 1 \\
\hline Abordagens de Mercado Convencional & $\begin{array}{l}\text { 1) Abordagem Dose-Resposta } \\
\text { 2) Técnica de Custos de Reposiçào }\end{array}$ & $\begin{array}{l}\text { 1)MDR } \\
\text { 2) MCR }\end{array}$ \\
\hline Funçoes de Produção Doméstica & $\begin{array}{l}\text { 3) Gastos Evitados } \\
\text { 4) Método de Custos de Viagem }\end{array}$ & $\begin{array}{l}\text { 3) MCE } \\
\text { 4) MCV }\end{array}$ \\
\hline Métodos de Preços Hedônicos & $\begin{array}{l}\text { 5) Preços de Casas (ou Terras) } \\
\text { 6) Salários pelo Risco }{ }^{75}\end{array}$ & $\begin{array}{l}\text { 5) } \mathrm{MPH} \\
\text { 6) } \mathrm{MPH}\end{array}$ \\
\hline Métodos Experimentais & $\begin{array}{l}\text { 7) Método de Valoraçào Contingente } \\
\text { 8) Método de Ordenaçào Contingente } \\
\text { (ou de Preferéncia Estabelecida/Fixa) }\end{array}$ & $\begin{array}{l}\text { 7) MVC } \\
\text { 8) Sem equivalente }\end{array}$ \\
\hline
\end{tabular}

n Wage Risk Methods (p.115).

Hanley \& Spash (1993) apud Nogueira et al. (2000), fazem apenas uma distinção dos métodos de valoração econômica ambiental em dois grupos:

1) forma direta, como o método de valoração contingente (MVC);

2) forma indireta, como o método de preços hedônicos (MPH), o método dos custos de viagem (MCV) e as abordagens da função de produção, como o método dos custos evitados (MCE) e o método dose-resposta (MDR).

\subsubsection{Apresentação dos Métodos de Valoração}

\subsubsection{Métodos diretos de valoração}

Os métodos diretos de valoração, descritos por Maia (2000), estimam o valor econômico do recurso ambiental a partir da própria disposição a pagar da população para bens e serviços ambientais. Partem do pressuposto que a variação da quantidade ou da qualidade do recurso ambiental irá afetar os padrões de bem estar das pessoas. 
Com a variação de bem estar, podemos estimar a disposição a pagar das pessoas para evitar; ou a disposição a receber para aceitar as alterações do ambiente.

\section{a) - Disposição a pagar direta - Método de Valoração Contingente - MVC}

O método de avaliação contingente (MVC) é um método direto de valoração econômica aplicado a bens e serviços não existentes no mercado. As pessoas são interrogadas sobre suas disposições a pagar para evitar/corrigir, ou a receber para aceitar a alteração na provisão de um bem e serviço ambiental, mesmo que nunca o tenha utilizado antes.

O MVC mensura as preferências do consumidor em situações Hipotéticas, através de jogos de leilão, escolha dicotômica (sim/não), jogos de trade-off etc. Após a aplicação desses questionários, os resultados são tabulados e submetidos a uma análise econométrica de maneira a derivar valores médios dos lances de disposição a pagar (DAP).

O MVC é mais aplicado para mensuração de:

a) recursos de propriedade comum ou bens cujo consumo é imprescindível à sobrevivência, tais como qualidade do ar ou da água;

b) recursos de amenidades, tais como característica paisagística, cultural, ecológica, histórica ou singularidade; ou

c) outras situações em que dados sobre preços de mercado estejam ausentes.

Este método, em muitos casos, é o único capaz de captar valores de existência de bens e serviços ambientais, e é adaptável à maioria dos problemas ambientais.

\section{b) - Disposição a pagar indireta - DAP indireta}

Os métodos obtêm indiretamente a disposição a pagar das pessoas para bens e serviços ambientais recorrendo a um mercado de bens complementares. Como exemplos de bens complementares, podemos citar a qualidade da água do mar que 
determina o número de visitas a uma praia, e a poluição sonora que influencia o preço das residências em uma região.

\section{b.1 - Método de Preços Hedônicos - MPH}

Este método estabelece uma relação entre os atributos de um produto e seu preço de mercado. Pode ser aplicado a qualquer tipo de mercadoria, embora seu uso seja mais freqüente em preços de propriedades.

A teoria econômica reconhece que as características ambientais, tais como qualidade do ar e da água, afetam a produtividade da terra, alterando os benefícios dos produtores e consumidores. A produtividade marginal impactará diretamente no preço das terras produtivas. Transportando este raciocínio para uma área residencial, o método de preços hedônicos supõe que as características ambientais irão interferir nos benefícios dos moradores, afetando também o preço de mercado das residências.

O método utiliza uma regressão de quadrados mínimos ordinários para ajustar o preço da residência às diversas características que possam inferir no seu valor. Além das características estruturais, como a área construída e o número de cômodos, e das características ambientais do local de construção, também farão parte do modelo econométrico os índices sócio-econômicos da região, e outros variáveis que possam influenciar o valor da residência.

\section{b.2 - Método Custo de Viagem - MCV}

O método é utilizado para a valoração de sítios naturais de visitação pública. O valor do recurso ambiental será estimado pelos gastos dos visitantes para se deslocar ao sítio, incluindo transporte, tempo de viagem, taxa de entrada e outros gastos complementares.

Avalia o comportamento do consumidor em situações reais, onde a idéia é que os gastos efetuados podem ser utilizados como uma aproximação dos benefícios proporcionados por essa recreação. 
A parte operacional se faz através de regressão múltipla para estimar a curva de demanda por visitas a partir de uma função de geração de viagens. Esta descreveria a quantidade de visitas que um indivíduo faria a um determinado lugar, considerando suas características socioeconômicas.

Os dados para definição da função, relacionando a taxa de visitação às variáveis de custo de viagem, tempo, taxa de entrada, característica sócio-econômicas do visitante, e outras variáveis que possam explicar a visita ao sítio natural, serão obtidos através de questionários aplicados a uma amostra da população no local de visitação.

A função de custo de viagem é incapaz de captar valores de não uso dos recursos ambientais, pois somente aqueles que visitam o sítio natural fazem parte do universo amostral.

\subsubsection{Métodos Indiretos de Valoração}

Conforme Maia (2000), os métodos indiretos de valoração estimam o valor de um recurso ambiental indiretamente através de uma função de produção. O objetivo é calcular o impacto de uma alteração marginal do recurso ambiental na atividade econômica, utilizando como referência produtos no mercado que sejam afetados pela modificação na provisão do recurso ambiental.

O impacto econômico sofrido na produção deste produto será uma estimativa dos benefícios embutidos no recurso ambiental.

Estes métodos exigem o conhecimento da relação entre a alteração ambiental e o impacto econômico na produção, que pode ser calculado diretamente no preço de mercado do produto afetado ou num mercado de bens substitutos.

Os métodos indiretos de valoração são divididos em dois outros subgrupos: o método de produtividade marginal e o método de mercado de bens substitutos. 


\section{a) - Método de Produtividade Marginal - MPM}

O método de produtividade marginal atribui um valor ao uso da biodiversidade relacionando a quantidade ou a qualidade de um recurso ambiental diretamente à produção de outro produto com preço definido no mercado. O papel do recurso ambiental no processo produtivo será representado por uma função dose-resposta, que relaciona o nível de provisão do recurso ambiental ao nível de produção respectivo do produto no mercado. Esta função irá mensurar o impacto no sistema produtivo, dada uma variação marginal na provisão do bem ou serviço ambiental, e a partir desta variação, estimar o valor econômico de uso do recurso ambiental.

O benefício ou custo da variação da disponibilidade do recurso ambiental é dado pelo produto da quantidade variada do recurso vezes o seu valor econômico estimado. Por exemplo, a perda de nutrientes do solo causada por desmatamento pode afetar a produtividade agrícola; a redução do nível de sedimentação numa bacia, por conta de um projeto de revegetação, pode aumentar a vida útil de uma hidrelétrica e sua produtividade; acréscimo do nível de contaminação da água representando a dose de poluição, e a queda da qualidade dos rios e a conseqüente diminuição da produção pesqueira.

Neste método (Santos, 2005), observa-se o valor do recurso ambiental E pela sua contribuição como insumo ou fator na produção de outro produto $\mathbf{Z i}$, isto é, o impacto do uso de E em uma atividade econômica.

Assim, estima-se a variação de produto de Zi decorrente da variação da quantidade de bens e serviços ambientais do recurso ambiental $\mathrm{E}$ utilizado na produção de Zi.

Sendo uma função de produção de $Z$, tal que o nível de produção de $Z i$ é dado pela seguinte expressão:

$$
Z=F(X, E)
$$


Onde, $\mathrm{X}$ é um conjunto de insumos formado por bens e serviços privados e $\mathrm{E}$ representa um bem ou serviço ambiental gerado por um recurso ambiental que é utilizado gratuitamente, ou seja, seu preço de mercado PE é zero. Note que E representa, assim, um valor de uso para a produção de Zi.

Sendo $P_{Z}$ e $P_{X}$ os preços de Zi e X, a função do lucro $(p)$ na produção de $Z$ seria:

$$
p=P_{Z} Q_{Z}-P_{X} Q_{X}-P_{E} Q_{E}=P Z F(X, E)-P X . Q X
$$

O produtor ajusta assim a utilização do seu insumo de forma a maximizar o seu lucro. Assumindo que a variação de Zi é marginal e, portanto, não altera seu preço, a variação de lucro seria:

$$
\begin{gathered}
\Delta \mathbf{p} / \Delta \mathbf{X}=\mathbf{P z} \Delta \mathrm{F} / \Delta \mathbf{X}-\mathbf{P X}=\mathbf{0} \\
\mathrm{e} \\
\Delta \mathbf{p} / \Delta \mathbf{E}=\mathbf{P z} \Delta \mathrm{F} / \Delta \mathrm{E}
\end{gathered}
$$

Ou seja, a variação de lucro do usuário de $\mathrm{E}$ é igual ao preço de Zi multiplicado pela variação de Zi quando varia $\mathrm{E}$.

O método de produtividade marginal, alternativamente denominado Método DoseResposta (MDR), assume que $\mathrm{P}_{Z}$ é conhecido e o valor econômico de $E\left(V_{E}\right)$ seria:

$$
\mathrm{VE}_{\mathrm{E}}=\mathrm{Pz} \Delta \mathrm{F} / \Delta \mathrm{E}
$$

Observe que $V E_{E}$, nestes casos, representa apenas valores de uso diretos ou indiretos relativos a bens e serviços ambientais utilizados na produção. Vale ressaltar que a estimação da função de produção F não é trivial quando as relações tecnológicas são complexas. 
Além do mais, as especificações de $\mathrm{E}$ em $\mathrm{F}$ são difíceis de serem captadas diretamente na medida em que $\mathrm{E}$ corresponde geralmente a fluxos de bens ou serviços gerados por um recurso ambiental que depende do seu nível de estoque ou de qualidade.

Logo, se faz necessário conhecer a correlação de $E$ em $F$ ou, se possível mais especificamente, as funções de dano ambiental ou as funções dose-resposta (DR) onde:

$$
E=D R(x 1, x 2, \ldots, Q E)
$$

Onde, xi são as variáveis que, junto com o nível de estoque (quantidade) ou qualidade $\mathbf{Q}$ do recurso, afetam o nível de $\mathrm{E}$. Assim,

$$
\Delta E=\Delta \mathbf{D} / \Delta \mathbf{Q E}
$$

Estas funções DRs procuram relacionar a variação do nível de estoque ou qualidade (respectivamente, taxas de extração ou poluição) com o nível de danos físicos ambientais e, em seguida, identificar o efeito do dano físico (decréscimo de E) em certo nível de produção específico.

Determinada a DR, é possível, então, estimar a variação do dano em termos de variação no bem ou serviço ambiental que afeta a produção de um bem.

Seguem as etapas necessárias para a quantificação do dano fazendo uso da função dose-resposta. 


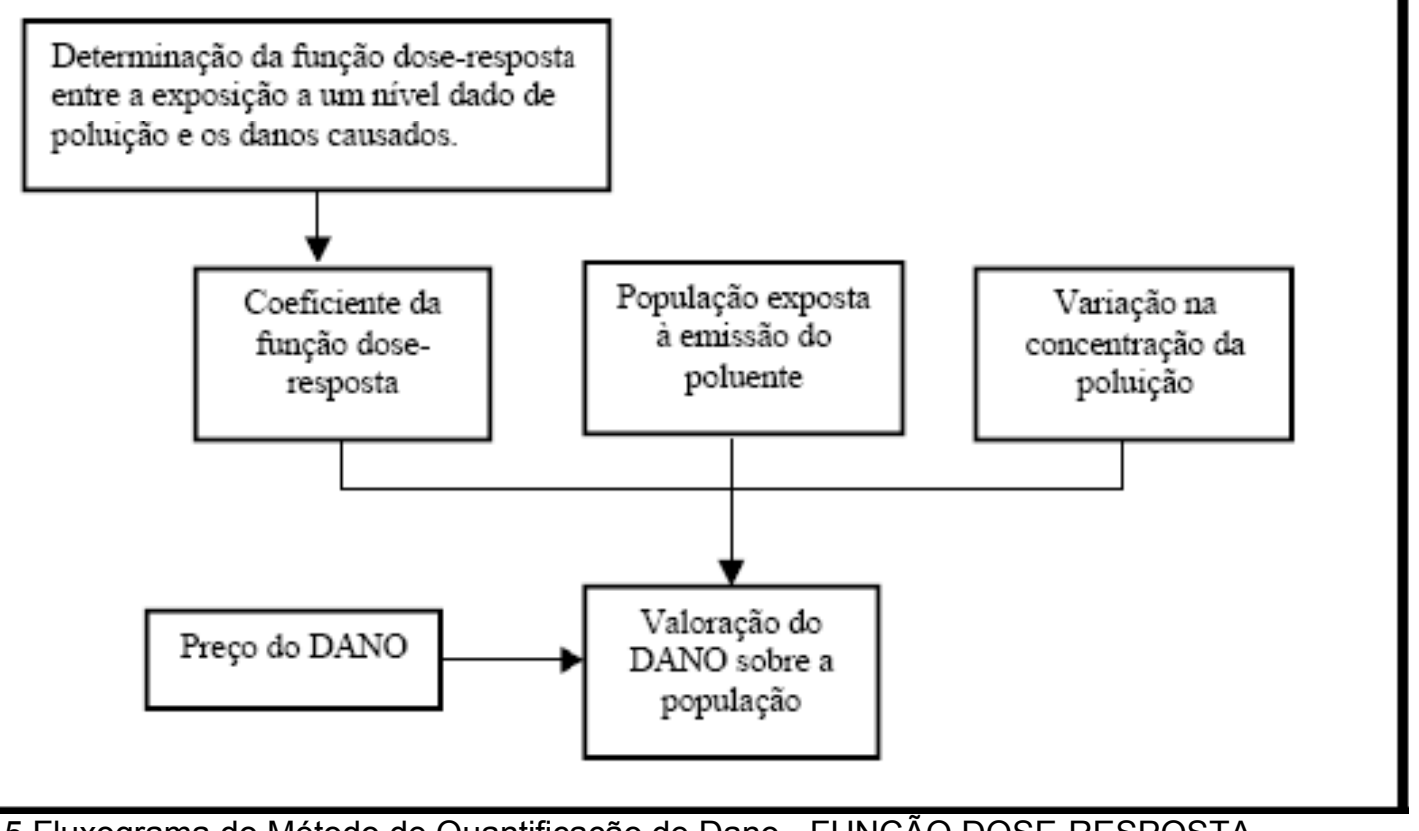

Figura 5 Fluxograma do Método de Quantificação de Dano - FUNÇÃO DOSE-RESPOSTA Fonte: Eletrobrás, 2000

A construção da função dose-resposta envolve duas etapas básicas. A primeira exige a elaboração de uma função física dos danos, relacionando a dose de poluição ou degradação à resposta do ativo ambiental poluído ou degradado na produção. A segunda corresponde à formulação de um modelo econômico que mensure o impacto financeiro destas alterações no processo produtivo.

Entretanto, a função de produção pode não ser tão trivial caso as relações biológicas e tecnológicas sejam demasiadamente complexas (Motta, 1998 apud Maia, 2002). A função exigiria a inclusão de múltiplas variáveis, e um estudo de campo bem detalhado para conhecimento de todos os agentes que participam do processo.

A tarefa de mensurar com precisão a provisão de bens ambientais já é muito complicada. Maiores dificuldades ainda serão encontradas na formulação de relacionamentos dose-resposta, que exigem sólidos conhecimentos sobre as ciências naturais (Pearce, 1993 apud Maia, 2002). É muito difícil precisar as relações causais ambientais, pois diversos benefícios tendem a ser afetados pela queda da qualidade ambiental, não somente aqueles do processo produtivo. Para conhecimento dos 
benefícios ou danos gerados são necessários, profundo conhecimento dos processos biológicos, capacidades técnicas e suas interações com as decisões dos produtores, e o efeito da produção no bem estar da população (Hanley \& Spash, 1993 apud Maia, 2002).

O método de produtividade marginal estima apenas uma parcela dos benefícios ambientais, e os valores tendem a ser subestimados. Os valores de existência, como a preservação das espécies, não fazem parte das estimativas, pois a função de produção capta apenas os valores de uso do recurso ambiental.

É um método que trata a qualidade ambiental como um fator de produção. Assim, "mudanças na qualidade ambiental levam a mudanças na produtividade e custos de produção, os quais levam, por sua vez, a mudanças nos preços e níveis de produção, que podem ser observados e mensurados (Hufschmidt et al., 1983, p.172 apud Nogueira, 2000; Santos, 2005)."

\section{b) - Mercado de bens substitutos}

A metodologia de mercado de bens substitutos parte do princípio de que a perda de qualidade ou escassez do bem ou serviço ambiental irá aumentar a procura por substitutos na tentativa de manter o mesmo nível de bem estar da população. Não obtendo diretamente o preço do bem por uma alteração ambiental, podemos estimá-lo pelo substituto existente no mercado.

Entretanto, é muito difícil encontrarmos na natureza um recurso que substitua com perfeição os benefícios gerados por outro recurso natural. Portanto, as estimativas são em geral sub-dimensionadas, pois tendem a considerar apenas os valores de uso dos recursos ambientais. Valores de existência, como o da preservação das espécies afetadas pelos danos, não entrarão no cálculo dos benefícios gerados pelo recurso ambiental, pois não fazem parte do mercado. 
Existem quatro técnicas derivadas do mercado de bens substitutos que são: custos evitados, custos de controle, custos de reposição e custos de oportunidade.

\section{b.1 - Método de Custos Evitados - MCE}

O método estima o valor de um recurso ambiental através dos gastos com atividades defensivas substitutas ou complementares, que podem ser consideradas uma aproximação monetária sobre as mudanças destes atributos ambientais.

Seria o caso de um indivíduo comprar água mineral engarrafada e/ou ferver a água encanada para se proteger de uma contaminação da água servida à população no local onde reside. São esses "gastos defensivos" ou "preventivos" dos indivíduos que são considerados nesse método. Neste exemplo, os gastos são adicionados conjuntamente de maneira a englobar todos os possíveis gastos efetuados pelo indivíduo para proteger a sua saúde, supõe-se que está avaliando todos os possíveis males da água poluída, e indiretamente valorando sua disposição a pagar pela água descontaminada.

Assim, ao tomar a decisão individual de comprar esses bens substitutos, grosso modo, ele está "valorando" essa perda na qualidade do recurso água potável em termos do valor de comprar a água engarrafada mais o custo de ferver a água encanada e mais as despesas médicas e o aborrecimento inerente por contrair uma doença.

A operacionalização do método é feita por meio de modelagem econométrica e daí a necessidade do manuseio dos dados por técnicos qualificados.

Os custos evitados são muito utilizados em estudos de mortalidade e morbidade humana e estudos relacionados com poluição e suas implicações sobre a saúde.

\section{b.2 - Método Custos de Controle - MCC}

O custo de controle representa os gastos necessários para evitar a variação do bem ambiental e manter a qualidade dos benefícios gerados à população. É o caso do tratamento de esgoto para evitar a poluição dos rios. 
Embora o controle da degradação limite o consumo presente do capital natural, ele mantém um nível sustentável de exploração e aumenta os benefícios da população em longo prazo, possibilitando o aproveitamento futuro dos recursos naturais.

As maiores dificuldades deste método estão relacionadas à estimação dos custos marginais de controle ambiental e dos benefícios gerados pela preservação. Os investimentos de controle ambiental tendem a gerar diversos benefícios, sendo necessário um estudo muito rigoroso para identificação de todos eles.

\section{b.3 - Método Custos de Reposição - MCR}

O MCR se baseia no custo de reposição ou restauração de um bem danificado e entende esse custo como uma medida do seu benefício (Pearce, 1993, p.105 apud Nogueira, 2000). Suas estimativas baseiam-se em preços de mercado para repor ou reparar o bem ou serviço danificado, partindo do pressuposto que o recurso ambiental possa ser devidamente substituído.

Uma das desvantagens do método é que, por maiores que sejam os gastos envolvidos na reposição, nem todas as complexas propriedades de um atributo ambiental serão repostas pela simples substituição do recurso.

É o caso do reflorestamento em áreas desmatadas e da fertilização para manutenção da produtividade agrícola em áreas onde o solo foi degradado. Os reflorestamentos estão longe de recuperar toda a biodiversidade existente em uma floresta nativa, assim como a reposição da fertilidade do solo através da adubação química nunca irá substituir a perda do solo que levou milhões de anos para se constituir.

Também o caso do padrão de qualidade da água, onde os custos para alcançá-lo são os benefícios que esse padrão proporciona à sociedade. Os riscos desse procedimento são que, ao impor uma reparação, a sociedade está sinalizando que os benefícios 
excedem os custos, quaisquer que sejam estes, e que, portanto, "os custos são uma medida mínima dos benefícios".

A operacionalização desse método é feita pela agregação dos gastos efetuados na reparação dos efeitos negativos provocados por algum distúrbio na qualidade ambiental de um recurso utilizado numa função de produção. Considere um monumento que, devido à poluição do ar, teve que ser submetido a uma limpeza com produtos químicos para recuperar as suas características anteriores. Na função de produção desse monumento, existe o parâmetro qualidade do ar para que ele se mantenha como um ponto turístico "atraente". Esses gastos com todo o processo de limpeza servem como uma medida aproximada do benefício que a sociedade aufere por ter esse monumento "visitável" e como fonte de recursos.

\section{b.4 - Método Custos de Oportunidade - MCO}

A preservação implica num custo que deve ser mensurado para permitir a divisão entre os diversos agentes que usufruem os benefícios da conservação. Toda conservação traz consigo um custo de oportunidade das atividades econômicas que poderiam estar sendo desenvolvidas na área de proteção. O custo de oportunidade representa as perdas econômicas da população em virtude das restrições de uso dos recursos ambientais. O benefício da conservação seria o valor de uso direto do recurso ambiental, estimado pela receita perdida em virtude do não aproveitamento em outras atividades econômicas.

Um parque ou reserva florestal com exploração restringida gera um custo de oportunidade da extração madeireira que poderia estar se desenvolvendo no local. Por outro lado, a extração acabaria impedindo outra receita, que seria o custo de oportunidade de atividades sustentáveis como o turismo e exploração de ervas medicinais. 
A estimativa da oportunidade de exploração deve sempre considerar uma possível diminuição do capital natural ao longo do tempo, que também é uma oportunidade futura de geração de renda.

Conforme apresentado, são várias as Metodologias de Valoração Econômica sendo que cada uma com especificidades, limitações e situações mais adequadas na sua aplicação, as quais devem ser consideradas de acordo com o objetivo que se deseja alcançar.

Neste trabalho, a aplicação da Metodologia de Produtividade Marginal analisa a água tratada para fins de abastecimento público como um produto, onde o recurso natural passa por um processo produtivo de tratamento.

O custo de produção sofre variação conforme a necessidade de aplicação dos insumos necessários para o tratamento. Para isso, é necessário avaliar uma função doseresposta entre a concentração dos poluentes existentes no recurso na captação, conforme os padrões estabelecidos pela legislação, e os efeitos sobre a qualidade da produção de água tratada.

A presença dos inúmeros poluentes presentes na água e seus respectivos efeitos que são monitorados pela Sabesp e Cetesb, conforme apresentados no próximo capítulo, definem as variáveis que devem ser analisadas para a aplicação da metodologia.

O conhecimento dos parâmetros de qualidade da água e sua relação com o uso e ocupação, que estão apresentados a seguir nas análises dos Índices de Qualidade da Água, desenvolvidos pela Sabesp e Cetesb, define as variáveis ambientais de causa para correção dos efeitos.

A variação do custo dos insumos necessários para correção da qualidade da água é o valor do impacto ambiental correspondente a uma determinada variação do parâmetro de qualidade da água analisado. 


\section{ANÁLISE DOS PARÂMETROS DE QUALIDADE DA ÁGUA COMO INSTRUMENTO DE VALORAÇÃO}

\subsection{Parâmetros de qualidade da água}

A poluição das águas tem como origem diversas fontes que estão associadas ao tipo de uso e ocupação do solo, possuindo características próprias quanto aos poluentes que carream. Dentre as quais se destacam:

- efluentes domésticos - apresentam compostos orgânicos biodegradáveis, nutrientes e bactérias

- efluentes industriais - contaminantes lançados aos corpos de água que estão relacionados aos tipos de matérias-primas e processos industriais utilizados.

- carga difusa urbana e agrícola - o deflúvio superficial urbano que contém todos os poluentes que se depositam na superfície do solo.Quando da ocorrência de chuvas, os materiais acumulados em valas, bueiros, etc., são arrastados pelas águas pluviais para os cursos de água superficiais, constituindo-se numa fonte de poluição tanto maior quanto mais deficiente for a coleta de esgotos ou mesmo a limpeza pública. Já o deflúvio superficial agrícola apresenta características diferentes onde, seus efeitos dependem muito das práticas agrícolas utilizadas em cada região e da época do ano em que se realiza a preparação do terreno para o plantio, a aplicação de fertilizantes, defensivos agrícolas e a colheita. A contribuição representada pelo material proveniente da erosão de solos intensifica-se quando da ocorrência de chuvas em áreas rurais.

A CETESB faz uso de 50 indicadores (parâmetros físicos, químicos, hidrobiológicos, microbiológicos e ecotoxicológicos) de qualidade de água, considerando-se aqueles mais representativos, devido a dificuldade na análise sistemática de todos os poluentes que possam estar presentes nas águas superficiais provenientes de diferentes formas de aporte. São eles:

_ Variáveis Físicas: absorbância no ultravioleta, coloração da água, série de resíduos (filtrável, não filtrável, fixo e volátil), temperatura da água e do ar e turbidez. 
_ Variáveis Químicas: alumínio, bário, cádmio, carbono orgânico dissolvido, chumbo, cloreto, cobre, condutividade específica, cromo total, demanda bioquímica de oxigênio (DBO5,20), demanda química de oxigênio (DQO), fenóis, ferro total, fluoreto, fósforo total, manganês, mercúrio, níquel, óleos e graxas, ortofosfato solúvel, oxigênio dissolvido, $\mathrm{pH}$, potássio, potencial de formação de trihalometanos, série de nitrogênio (Kjeldahl, amoniacal, nitrato e nitrito), sódio, surfactantes e zinco.

_ Variáveis Microbiológicas: Coliformes termotolerantes, Cryptosporidium sp e Giardia sp.

_ Variáveis Hidrobiológicas: clorofila a e feofitina a, fitoplâncton, zooplâncton e bentos (sublitoral).

_ Variáveis Toxicológicas: ensaio de toxicidade aguda com a bactéria luminescente V. fischeri (Sistema Microtox); ensaio de toxicidade aguda/crônica com o microcrustáceo Ceriodaphnia dubia; e ensaio de mutação reversa (conhecido como teste de Ames).

Cada parâmetro possui um significado ambiental, conforme descrito no anexo I, e são utilizados para caracterizar os Índices de Qualidade das Águas associados aos diferentes usos do recurso hídrico.

\subsection{Utilização dos parâmetros para elaboração dos Índices de Qualidade das Águas}

A CETESB utiliza desde 1975, o Índice de Qualidade das Águas - IQA, que representa uma média de diversas variáveis em um único número, combinando unidades de medidas diferentes em uma única unidade.

As variáveis de qualidade, que fazem parte do cálculo do IQA, refletem, principalmente, a contaminação dos corpos hídricos ocasionada pelo lançamento de esgotos domésticos. 
Esse índice foi desenvolvido para avaliar a qualidade das águas, tendo como determinante principal a sua utilização para o abastecimento público, considerando aspectos relativos ao tratamento dessas águas.

A crescente urbanização e industrialização de algumas regiões do Estado de São Paulo têm como conseqüência um maior comprometimento da qualidade das águas dos rios e reservatórios devido à complexidade de poluentes que estão sendo lançados no meio ambiente e à deficiência do sistema de coleta e tratamento dos esgotos gerados pela população. Sendo assim, a qualidade da água obtida através do IQA apresenta algumas limitações, entre elas a de considerar apenas a sua utilização para o abastecimento público. Além disso, mesmo considerando-se esse fim específico, o índice não contempla outras variáveis, tais como: metais pesados, compostos orgânicos com potencial mutagênico, substâncias que afetam as propriedades organolépticas da água, número de células de cianobactérias e o potencial de formação de trihalometanos das águas de um manancial.

Visando superar estas limitações, foi aprovada, em 13 de agosto de 1998, a Resolução SMA/65, que criou o Índice de Qualidade de Águas Brutas para Fins de Abastecimento Público (IAP) e o Índice de Preservação da Vida Aquática (IVA).

Tanto na Legislação Estadual (Decreto Estadual 8468/76) quanto na Federal (Resolução CONAMA 357/05), está estabelecido que os usos preponderantes para o recurso hídrico são dentre outros:

- Abastecimento público;

- Preservação do equilíbrio das comunidades aquáticas.

Desde 2002, a CETESB utiliza índices específicos para cada uso do recurso hídrico, sendo a avaliação da qualidade das águas composta por: 
IAP - Índice de Qualidade de Águas Brutas para Fins de Abastecimento Público e o IVA - Índice de Preservação da Vida Aquática e,

IB - Índice de Balneabilidade, que avalia as condições da água (devido seus múltiplos usos) para fins de recreação de contato primário.

O IAP, comparado com o IQA, é um índice mais fidedigno da qualidade da água bruta a ser captada, que após tratamento, será distribuída para a população. Do mesmo modo, o IVA foi considerado um indicador mais adequado da qualidade da água visando a proteção da vida aquática, por incorporar, com ponderação mais significativa, variáveis mais representativas, especialmente a toxicidade e a eutrofização.

\subsection{1. Índice de Qualidade das Águas Brutas para Fins de Abastecimento Público - IAP}

O IAP é o produto da ponderação dos resultados atuais do IQA (Índice de Qualidade de Águas) e do ISTO (Índice de Substâncias Tóxicas e Organolépticas), que é composto pelo grupo de substâncias que afetam a qualidade organoléptica da água, bem como de substâncias tóxicas. Assim, o índice será composto por três grupos principais de variáveis:

- IQA - grupo de variáveis básicas (Temperatura da Água, pH, Oxigênio Dissolvido, Demanda Bioquímica de Oxigênio, Coliformes Termotolerantes, Nitrogênio Total, Fósforo Total, Resíduo Total e Turbidez);

- $\quad$ ISTO -

a) Variáveis que indicam a presença de substâncias tóxicas (Teste de Ames Genotoxicidade, Potencial de Formação de Trihalometanos - PFTHM, Número de Células de Cianobactérias, Cádmio, Chumbo, Cromo Total, Mercúrio e Níquel);

b) Grupo de variáveis que afetam a qualidade organoléptica (Ferro, Manganês, Alumínio, Cobre e Zinco). 


\subsubsection{1. Índice de Qualidade das Águas - IQA}

Incorpora nove variáveis consideradas relevantes para a avaliação da qualidade das águas, tendo como determinante principal a sua utilização para abastecimento público.

Foram estabelecidas curvas de variação da qualidade das águas de acordo com o estado ou a condição de cada parâmetro.

O IQA é calculado pelo produtório ponderado das qualidades de água correspondentes às variáveis que integram o índice.

$$
\mathrm{IQA}=\prod_{i=1}^{\mathrm{n}} \mathrm{q}_{\mathrm{i}}^{\mathrm{w}_{\mathrm{i}}}
$$

Onde,

IQA: Índice de Qualidade das Águas, um número entre 0 e 100;

qi: qualidade do i-ésimo parâmetro, um número entre 0 e 100, obtido da respectiva "curva média de variação de qualidade", em função de sua concentração ou medida e, wi: peso correspondente ao i-ésimo parâmetro, um número entre 0 e 1, atribuído em função da sua importância para a conformação global de qualidade, sendo que:

$$
\sum_{i=1}^{n} w_{i}=1
$$

Onde, $\mathbf{n}$ é o número de variáveis que entram no cálculo do IQA.

A partir do cálculo efetuado, pode-se determinar a qualidade das águas brutas, que é indicada pelo IQA, variando numa escala de 0 a 100.

Tabela 4 - Classificação do IQA

\begin{tabular}{|c|c|}
\hline $\begin{array}{c}\text { Classificação do IQA } \\
\text { ÓTIMA }\end{array}$ & Categoria Ponderação \\
\hline BOA & $79<\mathrm{IQA} \leq 100$ \\
\hline REGULAR & $31<\mathrm{IQA} \leq 79$ \\
\hline RUIM & $19<\mathrm{IQA} \leq 51$ \\
\hline PÉSSIMA & $\mathrm{QA} \leq 19$ \\
\hline
\end{tabular}


Figura 6 - Curvas Médias de Variação de Qualidade das Águas
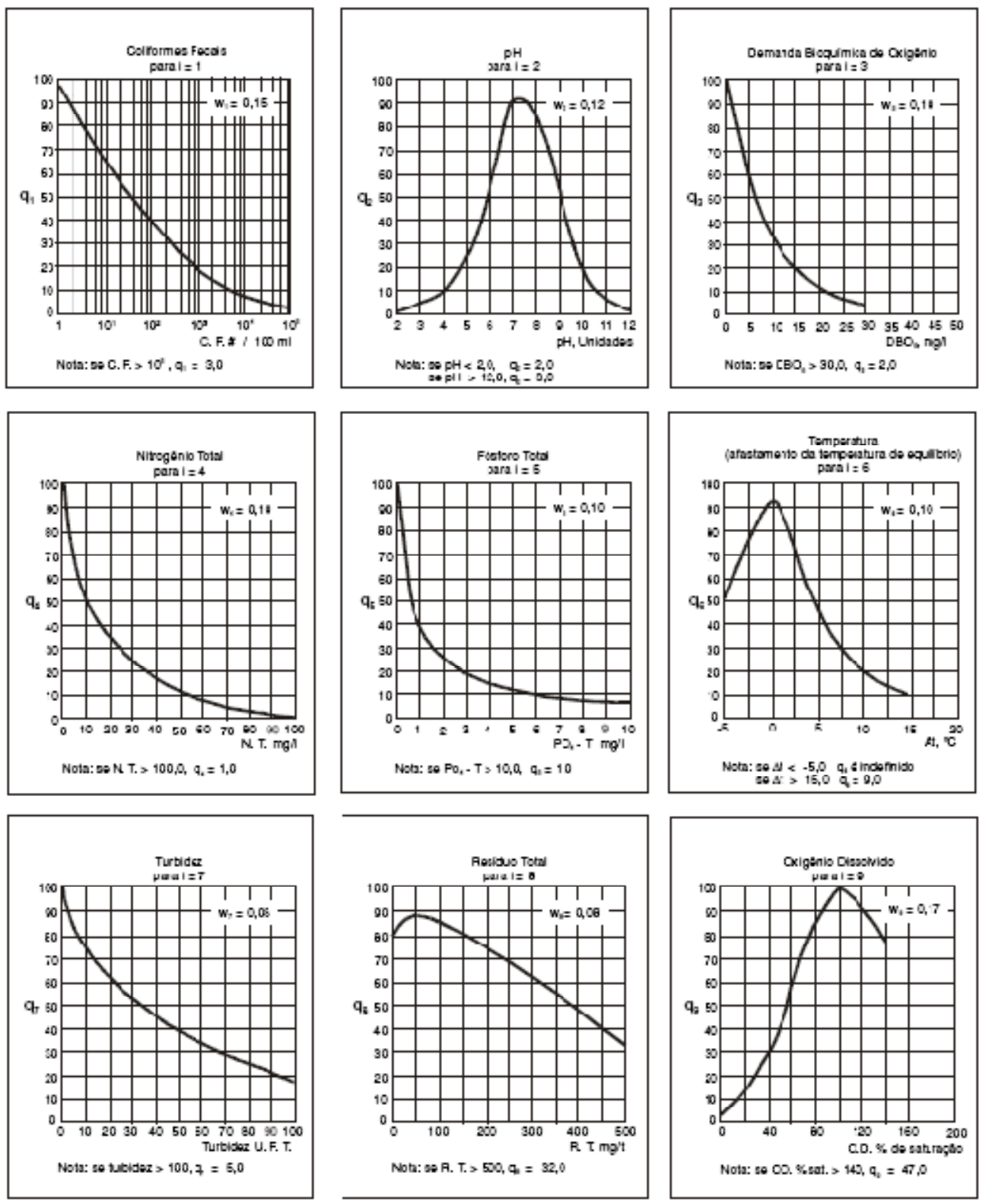

\subsubsection{2. Índice de Substâncias Tóxicas e Organolépticas - ISTO}

As variáveis que indicam a presença de substâncias tóxicas e que afetam a qualidade organoléptica são agrupadas de maneira a fornecer o Índice de Substâncias Tóxicas e Organoléptica (ISTO), utilizado para determinar o IAP, a partir do IQA original.

Para cada parâmetro incluído no ISTO são estabelecidas curvas de qualidade que atribuem ponderações variando de 0 a 1. 
As curvas de qualidade, representadas através das variáveis potenciais de formação de trihalometanos e metais, foram construídas utilizando-se dois níveis de qualidade (qi), que associam os valores numéricos 1.0 e 0.5, respectivamente, ao limite inferior (LI) e ao limite superior (LS). A Figura mostra a curva de qualidade padrão para as variáveis incluídas no ISTO, com exceção feita às variáveis testes de Ames e número de célula de cianobactérias.

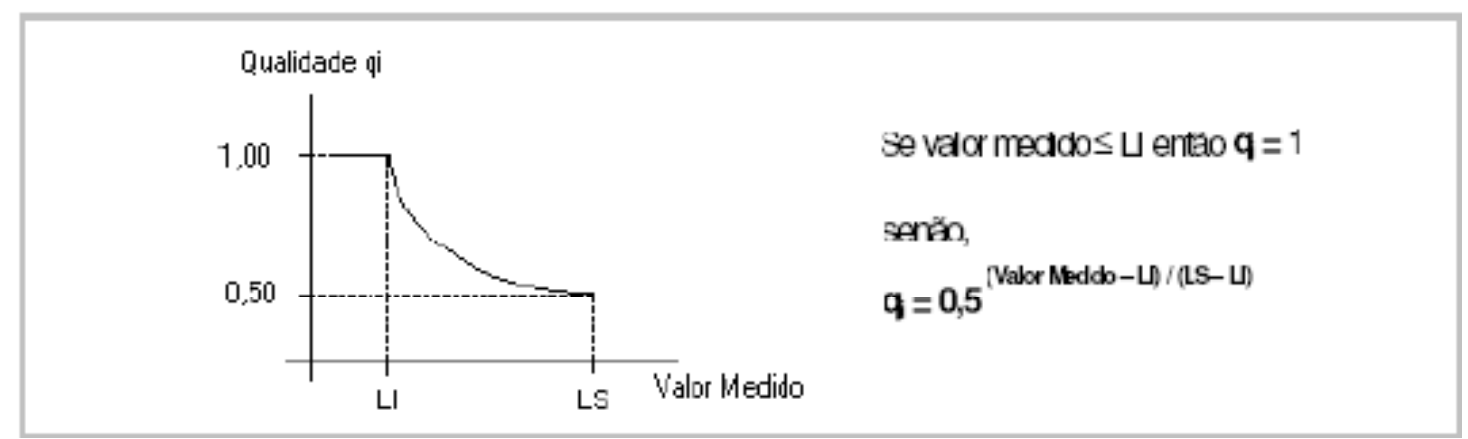

Figura 7 - Curva de qualidade padrão para as variáveis incluídas no ISTO

fonte: Relatórios "Qualidade das Águas Interiores no Estado de São Paulo" (CETESB).

As faixas de variação de qualidade (qi), que são atribuídas aos valores medidos para o potencial de formação de trihalometanos, para os metais que compõem o ISTO, refletem as seguintes condições de qualidade da água bruta destinada ao abastecimento público:

Valor medido < LI: águas adequadas para o consumo humano. Atendem aos padrões de potabilidade da Portaria 518/04 do Ministério da Saúde em relação às variáveis avaliadas.

LI < Valor medido < LS: águas adequadas para tratamento convencional. Atendem aos padrões de qualidade da classe 3 da Resolução CONAMA 357/05 em relação às variáveis determinadas.

Valor medido > LS: águas que não devem ser submetidas apenas a tratamento convencional. Não atendem aos padrões de qualidade da classe 3 da Resolução CONAMA 357/05 em relação às variáveis avaliadas.

Desta forma, o limite inferior para cada uma dessas variáveis foi considerado como sendo os padrões de potabilidade estabelecidos na Portaria 518/04 do Ministério da 
Saúde e para o limite superior foram considerados os padrões de qualidade de água doce Classe 3 da CONAMA 357/05.

Para o Cromo a CONAMA 357/05 estabelece um padrão de qualidade igual ao padrão de potabilidade da Portaria 518/04 (0,05 mg/l), portanto optou-se por adotar um nível de concentração para o limite superior que fosse passível de ser removido por meio de tratamento convencional. De acordo com o Drinking Water and Health, 1977, o Cromo possui uma taxa de remoção no tratamento convencional variando de 0 a $30 \%$. Aplicando-se uma taxa de remoção média de $15 \%$ ao limite inferior, obtém-se um limite superior de 0,059 mg/l.

O Zinco também possui um padrão de potabilidade igual ao padrão de qualidade CONAMA 357/05 (5,0 mg/l), adotou-se um nível de concentração para o limite superior que fosse passível de ser removido por meio de tratamento convencional.

Da mesma forma que o Cromo, o Drinking Water and Health, 1977, estabelece uma taxa de remoção no tratamento convencional variando de 0 a $30 \%$. Aplicando-se a taxa média de remoção de $15 \%$ ao limite inferior, obtém-se um limite superior de 5,9 mg/l.

Com relação ao Níquel não existe padrão de potabilidade na Portaria 518/04, sendo utilizado como referência a Organização Mundial da Saúde, que estabelece um valor de $0,02 \mathrm{mg} / \mathrm{l}$.

No caso do potencial de formação de THMs, foi estabelecida uma equação de regressão linear entre as variáveis potenciais de formação de THMs na água bruta e, trihalometanos na água tratada, para isso foram utilizados valores médios de 1997 a 2002, de ambas as variáveis, considerando os mananciais do Guarapiranga, Rio Grande, Cantareira, Baixo Cotia, Alto Cotia e Alto Tietê.

Tanto o limite superior quanto o inferior, foram obtidos por meio desta equação. O limite superior do potencial foi estimado para a concentração de THMs da Portaria 1469, de 
$100 \mu \mathrm{g} / \mathrm{l}$, enquanto que o inferior foi estimado a partir do nível de THMs estabelecido na legislação norte americana de $80 \mu \mathrm{g} / \mathrm{l}$. O limite superior do potencial de formação de THMs forneceu um valor de $461 \mu \mathrm{g} / \mathrm{l}$ e o inferior de $373 \mu \mathrm{g} / \mathrm{l}$.

Tabela 5 - Limites Superiores e Inferiores dos Metais e PFTHM

\begin{tabular}{|c|c|c|c|c|}
\hline Grupo & Variáveis & Unidade & Limite Inferior & Limite Superior \\
\hline \multirow{6}{*}{ Tóxicos } & Cádmio & $\mathrm{mg} / \mathrm{l}$ & 0,005 & 0,01 \\
\hline & Chumbo & $\mathrm{mg} / \mathrm{l}$ & 0,033 & 0,05 \\
\hline & Cromo Total & $\mathrm{mg} / \mathrm{l}$ & 0,05 & 0,059 \\
\hline & Níquel & $\mathrm{mg} / \mathrm{l}$ & 0,02 & 0,025 \\
\hline & Mercúrio & $\mathrm{mg} / \mathrm{l}$ & 0,001 & 0,002 \\
\hline & PFTHM & $\mu \mathrm{g} / \mathrm{l}$ & 373 & 461 \\
\hline \multirow{5}{*}{ Organolépticos } & Alumínio Dissolvido & $\mathrm{mg} / \mathrm{l}$ & 0,2 & 2 \\
\hline & Cobre Dissolvido & $\mathrm{mg} / \mathrm{l}$ & 1 & 4 \\
\hline & Ferro Dissolvido & $\mathrm{mg} / \mathrm{l}$ & 0,3 & 5 \\
\hline & Manganês & $\mathrm{mg} / \mathrm{l}$ & 0,1 & 0,5 \\
\hline & Zinco & $\mathrm{mg} / \mathrm{l}$ & 5 & 5,9 \\
\hline
\end{tabular}

fonte: Relatórios “Qualidade das Águas Interiores no Estado de São Paulo" (CETESB).

Nos pontos de amostragem, situados em ambientes lênticos e utilizados para abastecimento público, o número de células de cianobactérias é uma variável obrigatória para o cálculo do IAP, também é obrigatório em outros corpos lênticos, ou mesmo em rios, nos quais a freqüência de análise seja bimestral.

Portanto, através das curvas de qualidade, determinam-se os valores de qualidade normalizados, qi (número variando entre 0 e 1), para cada uma das variáveis do ISTO, que estão incluídas ou no grupo de substâncias tóxicas, ou no grupo de organolépticas.

A ponderação do grupo de substâncias tóxicas (ST) é obtida através da multiplicação dos dois valores mínimos mais críticos do grupo de variáveis que indicam a presença dessas substâncias na água: 
ST = Mín-1 (qTA; qTHMFP; qCd; qCr; qPb; qNi; qHg; qNCC,) x Mín-2 (qTA; qTHMFP; qCd; qCr; qPb; qNi; qHg; qNCC)

A ponderação do grupo de substâncias organolépticas (SO) é obtida através da média aritmética das qualidades padronizadas das variáveis pertencentes a este grupo:

$$
\text { SO = Média Aritmética (qAl; qCu; qZn; qFe; qMn) }
$$

O cálculo do ISTO é o resultado do produto dos grupos de substâncias tóxicas e as que alteram a qualidade organoléptica da água, como descrito a seguir:

$$
\text { ISTO }=\text { ST } \times \text { SO }
$$

\subsubsection{Cálculo do IAP}

O IAP é calculado a partir do produto entre o antigo IQA e o ISTO, segundo a seguinte expressão:

$$
\text { IAP }=\text { IQA x ISTO }
$$

Tabela 6 - Classificação do IAP

\begin{tabular}{|c|c|}
\hline $\begin{array}{c}\text { Categoria } \\
\text { ÓTIMA }\end{array}$ & Ponderação \\
\hline BOA & $51<$ IAP $\leq 100$ \\
\hline REGULAR $\leq 79$ \\
\hline RUIM & $36<$ IAP $\leq 51$ \\
\hline PESSIMA & $19<$ IAP $\leq 36$ \\
\hline
\end{tabular}

O IAP completo será designado como sendo aquele que inclui no grupo de Substâncias Tóxicas (ST) do ISTO, o Teste de Ames e o Potencial de Formação de THM e será aplicado para todos os pontos da Rede de Monitoramento que são utilizados para abastecimento público. Nos demais pontos, o IAP será calculado excluindo-se tais variáveis. 


\subsection{2. Índices de Qualidade das Águas para Proteção da Vida Aquática e de Comunidades Aquáticas - IVA}

O IVA leva em consideração a presença e concentração de contaminantes químicos tóxicos, seu efeito sobre os organismos aquáticos (toxicidade) e duas das variáveis consideradas essenciais para a biota $(\mathrm{pH}$ e oxigênio dissolvido), variáveis essas agrupadas no IPMCA - Índice de Variáveis Mínimas para a Preservação da Vida Aquática, bem como o IET - Índice do Estado Trófico de Carlson modificado por Toledo (1990). Desta forma, o IVA fornece informações não só sobre a qualidade da água em termos ecotoxicológicos, como também sobre o seu grau de trofia.

\subsubsection{1. Índice de Variáveis Mínimas para a Preservação da Vida Aquática - IPMCA} O IPMCA é composto por dois grupos de variáveis:

- Grupo de substâncias tóxicas (cobre, zinco, chumbo, cromo, mercúrio, níquel, cádmio, surfactantes e fenóis). Neste grupo foram incluídas as variáveis que são avaliadas pela Rede de Monitoramento de Qualidade das Águas Interiores do Estado de São Paulo e que identificam o nível de contaminação por substâncias potencialmente danosas às comunidades aquáticas. Poderão ser incluídas novas variáveis que venham a ser consideradas importantes para a avaliação da qualidade das águas, mesmo em nível regional.

- Grupo de variáveis essenciais (oxigênio dissolvido, $\mathrm{pH}$ e toxicidade).

Para cada variável incluída no IPMCA, são estabelecidos três diferentes níveis de qualidade, com ponderações numéricas de 1 a 3 e que correspondem a padrões de qualidade de água estabelecidos pela Resolução CONAMA 20/86, e padrões preconizados pelas legislações americana (USEPA, 1991) e francesa (Code Permanent: Environnement et Nuisances, 1986), que estabelecem limites máximos permissíveis de substâncias químicas na água, com o propósito de evitar efeitos de toxicidade crônica e aguda à biota aquática.

Esses níveis refletem as seguintes condições de qualidade de água: 
Nível A: Águas com características desejáveis para manter a sobrevivência e a reprodução dos organismos aquáticos. Atende aos padrões de qualidade da Resolução CONAMA 20/86 (ponderação 1).

Nível B: Águas com características desejáveis para a sobrevivência dos organismos aquáticos, porém a reprodução pode ser afetada em longo prazo (ponderação 2).

Nível C: Águas com características que podem comprometer a sobrevivência dos organismos aquáticos (ponderação 3).

Tabela 7 - Variáveis componentes do IPMCA e suas ponderações.

\begin{tabular}{|c|c|c|c|c|}
\hline Grupos & Variáveis & Níveis & Faixa de Variação & Ponderação \\
\hline \multirow{9}{*}{$\begin{array}{l}\text { Variáveis } \\
\text { Essenciais } \\
(\mathrm{PE})\end{array}$} & & $\mathrm{A}$ & $\geq 5,0$ & 1 \\
\hline & OD (mg/l) & $\mathrm{B}$ & 3,0 a 5,0 & 2 \\
\hline & & $\mathrm{C}$ & $<3,0$ & 3 \\
\hline & & A & 6,0 a 9,0 & 1 \\
\hline & PH (Sörensen) & $\mathrm{B}$ & 5,0 a $<6,0$ e $>9,0$ a 9,5 & 2 \\
\hline & & $\mathrm{C}$ & $<5,0$ e $>9,5$ & 3 \\
\hline & & A & Não tóxico & 1 \\
\hline & TOXIDADE & B & Efeito crônico & 2 \\
\hline & & $\mathrm{C}$ & Efeito agudo & 3 \\
\hline \multirow{23}{*}{$\begin{array}{l}\text { Substâncias } \\
\text { Tóxicas } \\
\text { (ST) }\end{array}$} & & A & $\leq 0,001$ & 1 \\
\hline & CADMIO (mg/l) & $\mathrm{B}$ & $>0,001$ a 0,005 & 2 \\
\hline & & $\mathrm{C}$ & $>0,005$ & 3 \\
\hline & & A & $\leq 0,05$ & 1 \\
\hline & CROMO (mg/l) & $\mathrm{B}$ & $>0,05$ a 1,00 & 2 \\
\hline & & $\mathrm{C}$ & $>1,00$ & 3 \\
\hline & & A & $\leq 0,02$ & 1 \\
\hline & COBRE (mg/l) & $\mathrm{B}$ & $>0,02$ a 0,05 & 2 \\
\hline & & $\mathrm{C}$ & $>0,05$ & 3 \\
\hline & & $\mathrm{A}$ & $\leq 0,03$ & 1 \\
\hline & CHUMBO (mg/l) & $\mathrm{B}$ & $>0,03$ a 0,08 & 2 \\
\hline & & $\mathrm{C}$ & $>0,08$ & 3 \\
\hline & & A & 0,0002 & 1 \\
\hline & MERCURIO (mg/l) & $\mathrm{B}$ & $>0,0002$ a 0,001 & 2 \\
\hline & & $\mathrm{C}$ & $>0,001$ & 3 \\
\hline & & A & $\leq 0,025$ & 1 \\
\hline & NIQUEL (mg/l) & $\mathrm{B}$ & $>0,025$ a 0,160 & 2 \\
\hline & & $\mathrm{C}$ & $>0,160$ & 3 \\
\hline & & A & $\leq 0,001$ & 1 \\
\hline & FENOIS (mg/l) & $\mathrm{B}$ & $>0,001$ a 0,050 & 2 \\
\hline & & $\mathrm{C}$ & $>0,050$ & 3 \\
\hline & & A & $\leq 0,5$ & 1 \\
\hline & $\begin{array}{l}\text { SURFACTANTES } \\
(\mathrm{mg} / \mathrm{l})\end{array}$ & B & $>0,5$ a 1,0 & 2 \\
\hline
\end{tabular}




\begin{tabular}{cccc}
\hline & $\mathrm{C}$ & $>1,0$ & 3 \\
\hline & $\mathrm{A}$ & $\leq 0,18$ & 1 \\
\hline ZINCO $(\mathrm{mg} / \mathrm{l})$ & $\mathrm{B}$ & $>0,18$ a 1,00 & 2 \\
\hline & $\mathrm{C}$ & $>1,00$ & 3 \\
\hline
\end{tabular}

Nível A: Padrões de qualidade de água da Legislação Federal (CONAMA 20/86), para classes 1 e 2 (BRASIL, 1986).

Níveis B e C: Limites obtidos da legislação francesa e americana (CODE PERMANENT: ENVIRONNEMENT ET NUISANCES, 1986), (USEPA, 1991).

\section{- Cálculo do IPMCA}

Dadas as ponderações para as variáveis determinadas em uma amostra de água, o IPMCA é calculado da seguinte forma:

\section{IPMCA = PE $\times$ ST}

onde:

PE: Valor da maior ponderação do grupo de variáveis essenciais;

ST: Valor médio das três maiores ponderações do grupo de substâncias tóxicas. Este valor é um número inteiro e o critério de arredondamento deverá ser o seguinte: valores menores que 0,5 serão arredondados para baixo e valores maiores ou iguais a 0,5 para cima.

O valor do IPMCA pode variar de 1 a 9 , sendo subdividido em quatro faixas de qualidade, classificando as águas para proteção da vida aquática, conforme a Tabela.

Tabela 8 - Classificação do IPMCA

\begin{tabular}{|c|c|}
\hline Categoria & Ponderação \\
\hline BOA & 1 \\
\hline REGULAR & 2 \\
\hline RUIM & 3 e 4 \\
\hline PESSIMA & $\geq 6$ \\
\hline
\end{tabular}




\subsubsection{2. Índice do Estado Trófico - IET}

O Índice do Estado Trófico tem por finalidade classificar corpos d'água em diferentes graus de trofia, ou seja, avalia a qualidade da água quanto ao enriquecimento por nutrientes e seu efeito relacionado ao crescimento excessivo das algas ou ao aumento da infestação de macrófitas aquáticas.

Das três variáveis citadas para o cálculo do Índice do Estado Trófico, foram aplicadas apenas duas: clorofila a e fósforo total, uma vez que os valores de transparência muitas vezes não são representativos do estado de trofia, pois esta pode ser afetada pela elevada turbidez decorrente de material mineral em suspensão e não apenas pela densidade de organismos planctônicos, além de muitas vezes não se dispor desses dados.

Nesse índice, os resultados correspondentes ao fósforo, IET(P), devem ser entendidos como uma medida do potencial de eutrofização, já que este nutriente atua como o agente causador do processo. A avaliação correspondente à clorofila a, IET (CL), por sua vez, deve ser considerada como uma medida da resposta do corpo hídrico ao agente causador, indicando de forma adequada o nível de crescimento de algas que tem lugar em suas águas. Assim, o índice médio engloba, de forma satisfatória, a causa e o efeito do processo. Deve-se ter em conta que num corpo hídrico, em que o processo de eutrofização encontra-se plenamente estabelecido, o estado trófico determinado pelo índice da clorofila a certamente coincidirá com o estado trófico determinado pelo índice do fósforo. Já nos corpos hídricos em que o processo esteja limitado por fatores ambientais, como a temperatura da água ou a baixa transparência, o índice relativo à clorofila a irá refletir esse fato, classificando o estado trófico em um nível inferior àquele determinado pelo índice do fósforo. Além disso, caso sejam aplicados algicidas, a conseqüente diminuição das concentrações de clorofila a resultará em uma redução na classificação obtida a partir do seu índice.

O Índice do Estado Trófico apresentado e utilizado no cálculo do IVA, será composto pelo Índice do Estado Trófico para o fósforo - IET (PT) e o Índice do Estado Trófico 
para a clorofila a - IET (CL), modificados por Lamparelli (2004), sendo estabelecidos para ambientes lóticos, segundo as equações:

- Rios

$$
\begin{aligned}
& \text { IET }(C L)=10 \times(6-((-0,7-0,6 \times(\ln C L)) / \ln 2))-20 \\
& \operatorname{IET}(P T)=10 \times(6-((0,42-0,36 x(\operatorname{In} P T)) / \ln 2))-20
\end{aligned}
$$

- Reservatórios

$$
\begin{aligned}
& \text { IET }(C L)=10 \times(6-((0,92-0,34 \times(\ln C L)) / \ln 2)) \\
& \text { IET }(P T)=10 \times(6-(1,77-0,42 \times(\operatorname{In} P T) / I n ~ 2))
\end{aligned}
$$

Onde:

PT: concentração de fósforo total medida à superfície da água, em $\mu \mathrm{g} . \mathrm{L}-1$;

CL: concentração de clorofila a medida à superfície da água, em $\mu g . L-1$;

In: logaritmo natural.

Nos meses em que estejam disponíveis dados de ambas variáveis, o resultado apresentado nas tabelas do IET será a média aritmética simples dos índices relativos ao fósforo total e a clorofila a, segundo a equação:

$$
\text { IET = [ IET ( PT ) + IET ( CL) ] / } 2
$$

$\mathrm{Na}$ interpretação dos resultados, os pontos são classificados conforme os resultados obtidos para o IET anual. Assim, para cada ponto, são utilizadas as médias geométricas das concentrações de fósforo total e clorofila a para cálculo do IET (PT) e IET (CL) anual, sendo o IET final resultante da média aritmética simples dos índices anuais relativos ao fósforo total e a clorofila a.

Em virtude da variabilidade sazonal dos processos ambientais que têm influência sobre o grau de eutrofização de um corpo hídrico, esse processo pode apresentar variações no decorrer do ano, havendo épocas em que se desenvolve de forma mais intensa e outras em que pode ser mais limitado. Em geral, no início da primavera, com o aumento da temperatura da água, maior disponibilidade de nutrientes e condições propícias de penetração de luz na água, é comum observar-se um incremento do processo, após o período de inverno, em que se mostra menos intenso. Nesse sentido, a determinação 
do grau de eutrofização médio anual de um corpo hídrico pode não identificar, de forma explícita, as variações que ocorreram ao longo do período anual, assim também serão apresentados os resultados mensais para cada ponto amostral.

No caso de não haver resultados para o fósforo total ou para a clorofila a, o índice é calculado com a variável disponível e considerado equivalente ao IET, devendo, apenas, constar uma observação junto ao resultado, informando que apenas uma das variáveis foi utilizada.

Estão estabelecidas as classificações de trofia para rios e reservatório conforme as tabelas:

Tabela 9 - Classificação do Estado Trófico para rios segundo Índice de Carlson Modificado

\begin{tabular}{|c|c|c|c|c|}
\hline \multicolumn{5}{|c|}{ Classificaçāo do Estado Trófico - Rlos } \\
\hline $\begin{array}{c}\text { Categoria } \\
\text { (Estado Trófico) }\end{array}$ & Ponderação & $\begin{array}{c}\text { Secchi - S } \\
(\mathrm{m})\end{array}$ & $\begin{array}{l}\text { P-total - P } \\
\left(\mathrm{mg} \cdot \mathrm{m}^{-3}\right)\end{array}$ & $\begin{array}{c}\text { Clorofilla a } \\
\left(\mathrm{mg} \cdot \mathrm{m}^{-3}\right)\end{array}$ \\
\hline Ultraoligotrófico & $\mathrm{IET} \leq 47$ & & $P \leq 13$ & $\mathrm{CL} \leq 0,74$ \\
\hline Oligotrófico & $47<\mathrm{IET} \leq 52$ & & $13<P \leq 35$ & $0,74<\mathrm{CL} \leq 1,31$ \\
\hline Mesotrófico & $52<\mathrm{IET} \leq 59$ & & $35<P \leq 137$ & $1,31<\mathrm{CL} \leq 2,96$ \\
\hline Eutrófico & $59<\mathrm{IET} \leq 63$ & & $137<P \leq 296$ & $2,96<\mathrm{CL} \leq 4,70$ \\
\hline Supereutrofico & $63<\mathrm{IET} \leq 67$ & & $296<P \leq 640$ & $4,70<\mathrm{CL} \leq 7,46$ \\
\hline Hipereutrófico & $\mathrm{IET}>67$ & & $640<P$ & $7,46<\mathrm{CL}$ \\
\hline
\end{tabular}

Tabela 10 - Classificação do Estado Trófico para reservatórios segundo Índice de Carlson Modificado

\begin{tabular}{|c|c|c|c|c|}
\hline \multicolumn{5}{|c|}{ Classificação do Estado Trófico - Reservatórios } \\
\hline $\begin{array}{c}\text { Categoria } \\
\text { (Estado Trófico) }\end{array}$ & Ponderaçāo & $\begin{array}{c}\text { Secchi - S } \\
(\mathrm{m})\end{array}$ & $\begin{array}{l}\text { P-total - P } \\
\left(\mathrm{mg} \cdot \mathrm{m}^{-3}\right)\end{array}$ & $\begin{array}{c}\text { Clorofilla } a \\
\left(\mathrm{mg} \cdot \mathrm{m}^{-3}\right)\end{array}$ \\
\hline Ultraoligotrófico & $\mathrm{IET} \leq 47$ & $S \geq 2,4$ & $P \leq 8$ & $C L \leq 1,17$ \\
\hline Oligotrófico & $47<\mathrm{IET} \leq 52$ & $2,4>S \geq 1,7$ & $8<P \leq 19$ & $1,17<\mathrm{CL} \leq 3,24$ \\
\hline Mesotrófico & $52<\mathrm{IET} \leq 59$ & $1,7>S \geq 1,1$ & $19<P \leq 52$ & $3,24<\mathrm{CL} \leq 11,03$ \\
\hline Eutrófico & $59<\mathrm{IET} \leq 63$ & $1,1>S \geq 0,8$ & $52<P \leq 120$ & $11,03<\mathrm{CL} \leq 30,55$ \\
\hline Supereutrófico & $63<\mathrm{IET} \leq 67$ & $0,8>S \geq 0,6$ & $120<\mathrm{P} \leq 233$ & $30,55<\mathrm{CL} \leq 69,05$ \\
\hline Hipereutrófico & $\mid E T>67$ & $0,6>S$ & $233<P$ & $69,05<\mathrm{CL}$ \\
\hline
\end{tabular}

Tabela 11 - Classificação do IET 


\begin{tabular}{|c|c|}
$\begin{array}{c}\text { Categoria } \\
\text { (Estado Trófico) }\end{array}$ & Ponderaçāo \\
\hline Ultraoligotrófico & 0,5 \\
\hline Oligotrófico & 1 \\
\hline Mesơrófico & 2 \\
\hline Eutrófico & 3 \\
\hline Supereutrófico & 4 \\
\hline Hipereutrofico & 5 \\
\hline
\end{tabular}

A partir daí, introduz-se índices para o IET sem que haja alteração da classificação original do IVA. O valor resultante do índice descreve cinco classificações de qualidade:

Tabela 12 - Classificação do IVA

\begin{tabular}{|c|c|}
\hline Categoria & Ponderação \\
\hline OTIMA & IVA $\leq 2,2$ \\
\hline BOA & $2,9 \leq$ IVA $\leq 3,2$ \\
\hline REGULAR & $3,4 \leq$ IVA $\leq 4,4$ \\
\hline RUIM & $4,6 \leq$ IVA $\leq 6,6$ \\
\hline PESSIMA & $6,8 \leq$ IVA $>7,6$ \\
\hline
\end{tabular}

5.2.2.3. Tabela 13 - Cálculo do IVA integrando os valores do IET com os valores do IPMCA, com as classificações de qualidade resultante

\begin{tabular}{|c|c|c|c|c|c|c|}
\hline \multicolumn{7}{|c|}{ IPMCA } \\
\hline \multirow{4}{*}{ IET } & PONDERAÇÃO & $\mathbf{1}$ & $\mathbf{2}$ & $\mathbf{3}$ & $\mathbf{4}$ & $\mathbf{5}$ \\
\cline { 2 - 7 } & 0,5 & 1,7 & 2,9 & 4,1 & 5,3 & $7,7-11,3$ \\
\cline { 2 - 7 } & 1 & 2,2 & 3,4 & 4,6 & 5,8 & $8,2-11,8$ \\
\cline { 2 - 7 } & 2 & 3,2 & 4,4 & 5,6 & 6,8 & $9,2-12,8$ \\
\cline { 2 - 7 } & 3 & 4,2 & 5,4 & 6,6 & 7,8 & $10,2-13,8$ \\
\cline { 2 - 7 } & 4 & 5,2 & 6,4 & 7,6 & 8,8 & $11,2-14,8$ \\
\cline { 2 - 7 } & 5 & 6,2 & 7,4 & 8,6 & 9,8 & $12,2-15,8$ \\
\hline
\end{tabular}

Categoria

\begin{tabular}{ll|l|l|l|l} 
OTIMA & BOA & REGULAR & RUIM & & PESSIMA
\end{tabular}

De acordo com as legislações estadual (Regulamento da Lei 997/76, aprovado pelo Decreto Estadual 8468/76) e federal (Resolução CONAMA 20/86), a proteção das 
comunidades aquáticas está prevista para corpos d'água enquadrados nas classes 1, 2 e 3, sendo, portanto, pertinente a aplicação do IVA somente para esses ambientes. Assim sendo, para os corpos d'água enquadrados na classe 4 não é aplicado o IVA.

Se, em uma dada amostra, não houver o resultado do teste de toxicidade, mas existirem resultados de oxigênio dissolvido e $\mathrm{pH}$, o IVA é calculado nas seguintes condições:

- Quando a concentração do oxigênio dissolvido for menor do que 3 mg/l;

- Quando o teste de toxicidade for semestral.

Nesses casos, a ausência de resultados do grupo de Substâncias Tóxicas do IPMCA não implica na inviabilidade do cálculo do IVA.

\subsection{3. Índice de Balneabilidade - IB}

O Índice de Balneabilidade visa avaliar a qualidade da água para fins de recreação de contato primário, sendo aplicado em praias de águas interiores, localizadas em rios e reservatórios.

A CETESB desenvolveu, a partir dos resultados obtidos no monitoramento semanal e mensal, uma Qualificação Anual, que baseada em critérios estatísticos simplificados, expressa uma síntese da qualidade das águas monitoradas ao longo do ano.

Nas praias onde são realizadas classificações semanais, o IB é obtido através de uma síntese das classificações ao longo das 52 semanas do ano. As praias onde são realizadas classificações mensais, o IB é calculado a partir das densidades de $E$. coli.

Tabela 14 - Qualificação Anual para as praias com classificações semanais e mensais.

Índice de Balneabilidade - IB 


\begin{tabular}{|c|c|c|}
\hline Categoria & Praia Semanal & Praia Mensal \\
\hline ÓTIMA & $\begin{array}{l}\text { Praias classificadas como } \\
\text { EXCELENTES em } 100 \% \text { do ano. }\end{array}$ & $\begin{array}{l}\text { Número de resultados de Coliformes } \\
\text { Termotolerantes menores do que } 250 \\
\text { ou E. coli menores do que } 200 \text { em } \\
100 \% \text { do ano. }\end{array}$ \\
\hline $\mathrm{BOA}$ & $\begin{array}{l}\text { Praias próprias em } 100 \% \text { do ano, } \\
\text { exceto as classificadas como } \\
\text { EXCELENTES em } 100 \% \text { do ano. }\end{array}$ & $\begin{array}{l}\text { Número de resultados de Coliformes } \\
\text { Termotolerantes menores do que } \\
1.000 \text { ou } E \text {. coli menores do que } 800 \\
\text { em } 100 \% \text { do ano, exceto a condiçăo } \\
\text { de menores do que } 250 \text { e } 200 \text { em } \\
100 \% \text { do ano. }\end{array}$ \\
\hline REGULAR & $\begin{array}{l}\text { Praias classificadas como } \\
\text { IIMPRÓPRIAS em porcentagem de } \\
\text { tempo inferior a } 50 \% \text { do ano. }\end{array}$ & $\begin{array}{l}\text { Número de resultados de Coliformes } \\
\text { Termotolerantes maiores do que } \\
1.000 \text { ou } E_{\text {. coli maiores do que } 800} \\
\text { em porcentagem inferior a } 50 \% \text { do } \\
\text { ano. }\end{array}$ \\
\hline MÁ & $\begin{array}{l}\text { Praias classificadas como } \\
\text { IIMPRÓPRIAS em porcentagem de } \\
\text { tempo igual ou superior a } 50 \% \text { do } \\
\text { ano. }\end{array}$ & $\begin{array}{l}\text { Número de resultados de coliformes } \\
\text { Termotolerantes maiores do que } \\
1.000 \text { ou } E_{\text {. coli maiores do que } 800} \\
\text { em porcentagem igual ou superior a } \\
50 \% \text { do ano. }\end{array}$ \\
\hline
\end{tabular}

Como apresentado, são monitorados e analisados, pelas empresas, diversos parâmetros de qualidade da água, obtendo-se, como resultado, índices que são indicadores da qualidade do recurso relacionados ao seu uso.

Portanto, o levantamento de dados monitorados e analisados, pela Sabesp e Cetesb, da região "estudo de caso", apresentado no próximo capítulo, fornece a base para a aplicação da metodologia de valoração adequada ao estudo.

A escolha da metodologia de valoração econômica associada à existência dos parâmetros de qualidade da água, já analisados, permite dimensionar o valor econômico do impacto a partir da correção deste. 


\section{ESTUDO DE CASO - BACIA DO GUARAPIRANGA}

Na bacia do Guarapiranga se evidencia um processo de crescimento urbano associado à ocupação irregular do solo, o que acarreta como conseqüência, a degradação ambiental.

A situação atual da bacia é bastante complexa, observando-se diversos usos e atividades conflitantes com a preservação do manancial de abastecimento de água. Além disso, existem limitações econômicas e financeiras do poder público que impedem soluções como desapropriações de áreas da bacia e transferência de parte significativa da população para outras áreas.

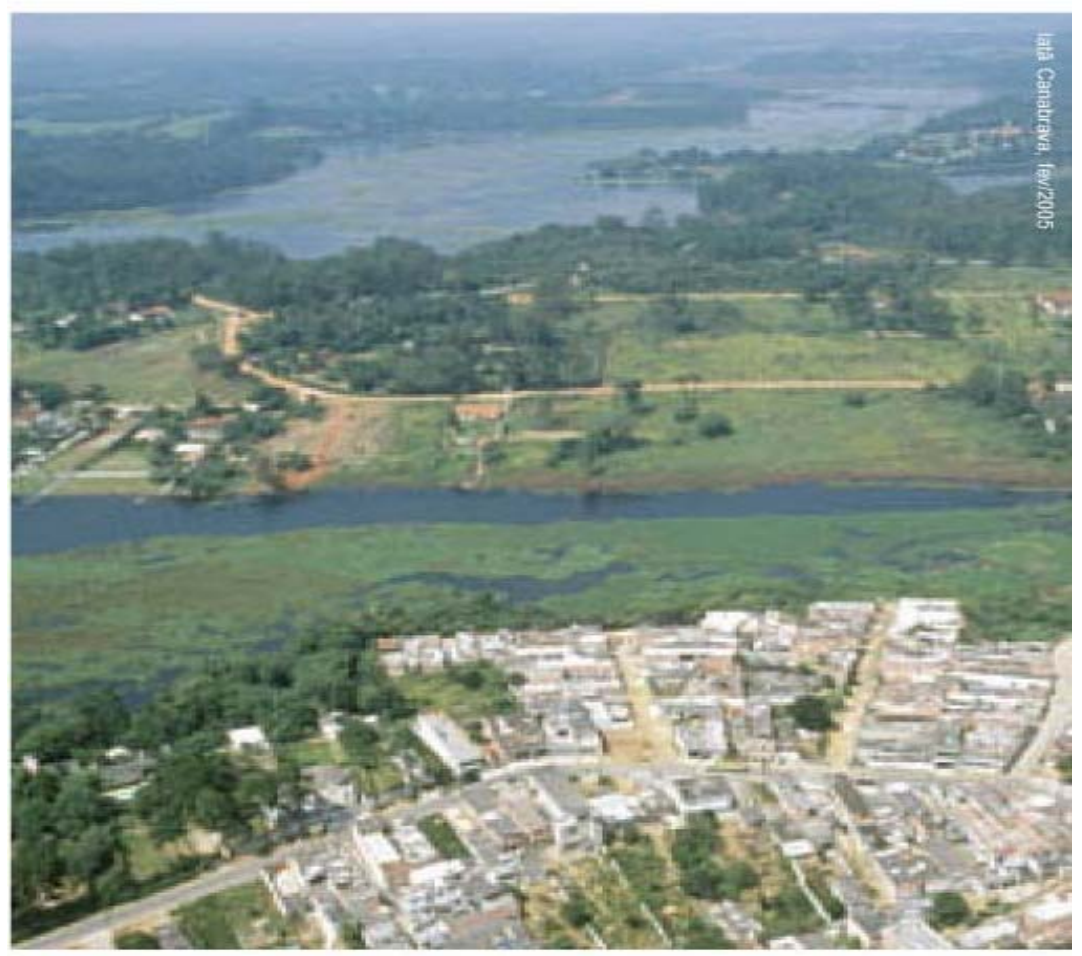

A Bacia Hidrográfica da Guarapiranga apresenta parte significativa de seu território ocupada por usos antrópicos e áreas urbanas próximas à represa 


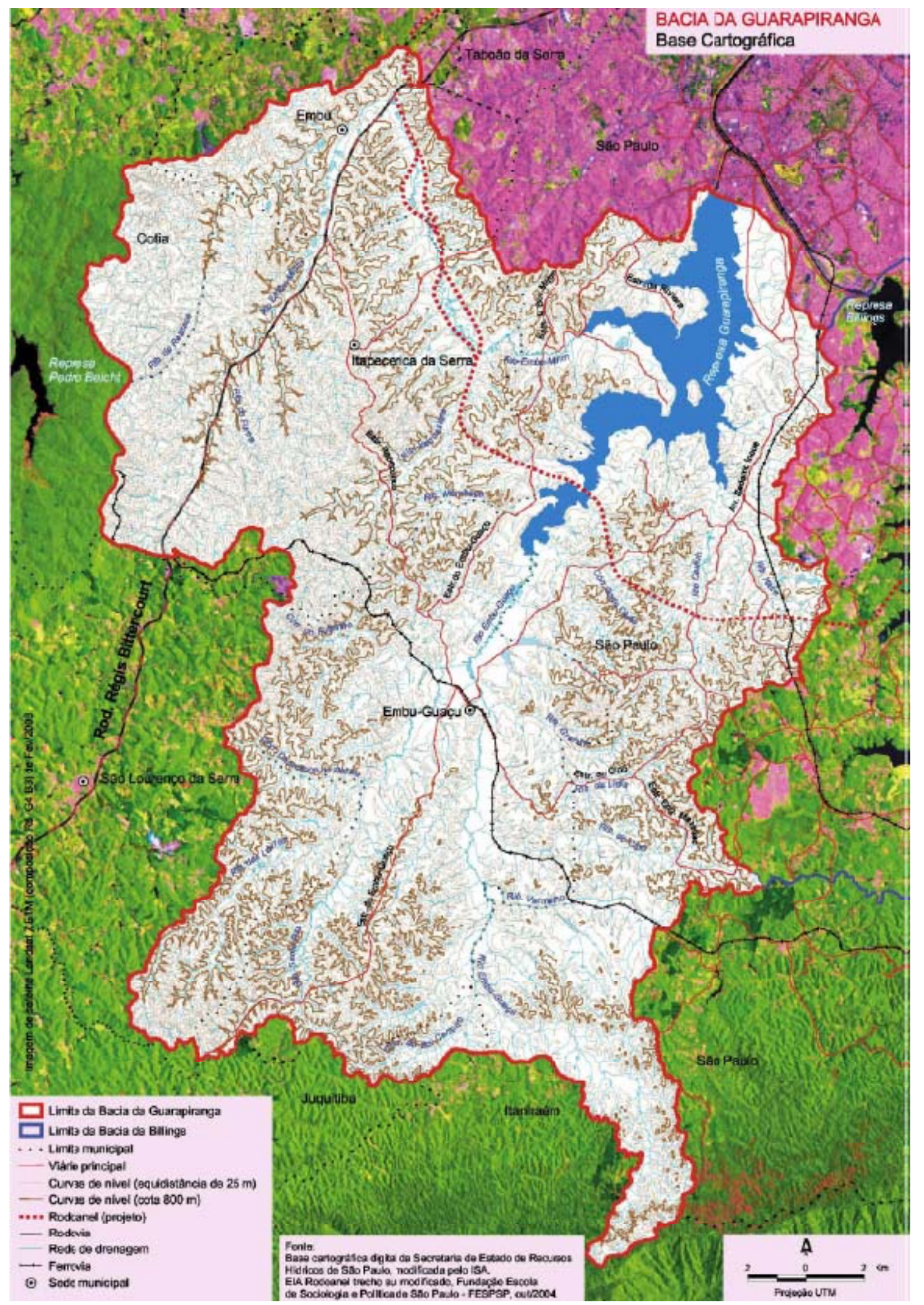




\subsection{Histórico de formação da Represa do Guarapiranga}

Como relatado por França et al (2000), em 1899, a empresa de origem canadense Light foi autorizada a operar no Brasil, nas cidades de São Paulo e Rio de Janeiro, explorando a produção e distribuição de energia elétrica, além dos serviços de iluminação e transporte coletivo. Em 1901, a empresa inaugurou a primeira Usina Hidrelétrica em Parnaíba.

Devido ao aumento da demanda de energia ocasionado pela industrialização, expansão de linhas de bondes, iluminação pública, foi necessário aumentar a capacidade de geração de energia. Com isso, na Usina Hidrelétrica de Parnaíba, foram instaladas novas turbinas, o que trouxe a necessidade de regularizar a vazão do Rio Tiête. Para isso, a Light decidiu construir um grande reservatório de regularização, onde, durante o período de estiagem no rio Pinheiros, que segue em direção ao rio Tietê, a águas seriam descarregadas para alimentar as turbinas da Usina Hidrelétrica de Parnaíba.

O local escolhido foi o rio Guarapiranga, cujas águas, afluentes do rio Pinheiros, foram represadas formando um lago artificial que acumulou cerca de 200 milhões de metros cúbicos de água, ocupando uma grande extensão de terra que era cultivada por pequenos sitiantes e chacareiros. As obras de construção da barragem iniciaram em 1906 e finalizaram em 1909. O lago ficou com um perímetro de $85 \mathrm{~km}$, inundando uma área de $34 \mathrm{~km} 2$. Na sua parte mais funda, próximo da barragem, a profundidade era de $13 \mathrm{~m}$ e no restante a média era de $6 \mathrm{~m}$.

O motivo dessa escolha deveu-se a vários estudos que analisaram aspectos técnicos como pluviosidade e composição do solo e aspectos econômicos como uso do solo e o valor da desapropriação, que não representava um alto investimento, pois as terras compradas não eram valorizadas.

Embora surgisse para fins de controle de vazões do sistema de geração de energia, o reservatório revelou potencialidades relacionadas à recreação. Com isso, após a construção da represa do Guarapiranga, intensificou-se a função recreativa marcando a 
tendência de ocupação do entorno da represa, desde 1920, e definindo as formas de uso e ocupação do solo e as atividades econômicas da região.

Devido ao fato da bacia do Guarapiranga ser considerada completamente preservada, e estar próxima da capital, a partir de 1928, o reservatório passou a ser a principal fonte de água na função de abastecimento público para a capital, mediante o fornecimento de 86,4 milhões de litros por dia (vazão média de $1 \mathrm{~m} 3 / \mathrm{s}$ ). Aliado a isso, a Light para aumentar seu potencial gerador, iniciou o projeto de retificação do rio Pinheiros; de retificação e represamento do rio Jurubatuba construindo uma nova represa, a Billings, o que proporcionou que a represa do Guarapiranga deixasse de ser um reservatório regulador de vazão do rio Tietê.

E, em 1929, foi inaugurado o Sistema de Abastecimento do Guarapiranga, segundo em capacidade de produção de água da capital menor apenas que o Sistema Cantareira.

Em 1958, com a construção da estação de tratamento de água do Alto da Boa Vista, a represa passou a fornecer $9,5 \mathrm{~m} 3 / \mathrm{s}$.

Para proteção dos mananciais, a Repartição de Águas e Esgotos - RAE, órgão estadual que era responsável pelo abastecimento de água, adotava a política de desapropriação das terras da bacia de contribuição dos reservatórios, mas, no sistema Guarapiranga, isso não aconteceu. Somente foram adquiridos os terrenos da área de inundação, isso porque, o reservatório era de propriedade da Light e foi construído com fins energéticos. Porém, a empresa se comprometeu em manter o reservatório em condições de saneamento, enquanto as águas abastecessem a capital.

\section{Ocupação pela Elite}

A região de Santo Amaro, antes mesmo de ser anexada a São Paulo em 1935, pelo Decreto Estadual $n^{\circ}$. 6.983, tornou-se privilegiada para os investimentos imobiliários, principalmente os voltados à burguesia paulistana, tanto pela disponibilidade de terras como pela aprazível paisagem do lago construído pela Light. 
O projeto de urbanização da região de Interlagos, às margens da Represa do Guarapiranga, foi sendo implantado a partir de 1937, no empreendimento "Cidade Satélite Balneária de Interlagos", com área de 4 milhões de $\mathrm{m}^{2}$, que contava com infraestrutura urbana, como água, luz elétrica, calçamento, amplas avenidas, aliada à paisagem da represa, com praia artificial, bosques, clima saudável, e a possibilidade de lazer e esportes náuticos, oferecidos pelos vários clubes que se instalaram. E, em 1939, começaram a ser construídos o autódromo e a avenida que seguia direto à "Cidade Satélite".

No interior da bacia, o parcelamento do solo urbano, pré-existente à Lei de Proteção aos Mananciais (1975/1976), caracterizava-se pela coexistência entre loteamentos de alto padrão atraídos para a região pelo potencial paisagístico e de lazer proporcionado pela represa, com outros de renda média e loteamentos periféricos. Além de chácaras de recreio, na zona rural, e certo número de clubes recreativos à beira da represa.

Devido a melhores condições de acessibilidade na área da margem direita, predominaram loteamentos de padrão mais altos e vários clubes recreativos, coexistindo loteamentos de padrão médio. Mais ao sul verificava-se a dispersão da urbanização, com grandes vazios de uso rural.

Nos anos 80, grandes investimentos centrados em projetos residenciais para a população de alta renda e em conjuntos comerciais e de serviços de ultima geração provocaram a verticalização e o adensamento da ocupação do solo, com conseqüente valorização imobiliária.

Ocupação das Marginais do Rio Pinheiros devido ao Pool de Crescimento Industrial e Desenvolvimento de Vias de Acesso - Expansão da Periferia com maior Ocupação da Bacia do Guarapiranga

As obras da Represa do Guarapiranga e, posteriormente da Represa Billings, além da canalização e retificação do Rio Pinheiros, deram impulso à ocupação das suas margens, que antes eram várzeas desabitadas. A conclusão dessas obras, nos anos 40 
e 50, foram complementadas na década de 60 pelo projeto das vias marginais do canal do rio Pinheiros, que reforçaram o direcionamento da expansão urbana para a zona sul, consolidando o parque industrial de Santo Amaro e ocorrendo a expansão da malha urbana metropolitana, e dos investimentos das classes de renda mais altas nas direções sul - sudoeste. Essas intervenções urbanas transformaram a região e potencializaram o interesse por empreendimentos privados.

A partir dos anos 50, tem início o processo de degradação, onde mudanças advindas da implantação sempre crescente de indústrias na zona sul provocam a ocupação desordenada da região em decorrência da ampliação da demanda por áreas habitacionais.

Na década de 60, a concentração de renda intensificou-se e, a lógica da construção da cidade passou pelo deslocamento das centralidades, associado à exclusão territorial dos mais pobres.

A ocupação da margem esquerda da represa, devido a vários fatores como maior distância ao centro da cidade e topografia mais acidentada, em função da pressão por moradia popular e emprego, fez com que predominassem os loteamentos irregulares e as favelas.

Esta expansão foi fortalecida pela proximidade a áreas de concentração de empregos, com a consolidação do pólo industrial de Santo Amaro e posteriormente, entre os anos 70 e 80 , com o deslocamento do setor terciário avançando em direção ao vale do Rio Pinheiros.

Na década de 70, núcleos urbanos precários começaram a se instalar no território, caracterizados por lotes menores, inexistência de infra-estrutura e densidades populacionais maiores. 
Essa expansão de características periféricas, também, foi facilitada pelos principais eixos de penetração viária rumo ao interior da bacia. A partir do quadrante noroestesudeste, as marginais ao canal do Rio Pinheiros se conectam com a estrada do Guarapiranga, a estrada de M'Boi Mirim na margem esquerda, a oeste do reservatório, e avenidas Robert Kennedy e do Rio Bonito, que se liga à avenida Interlagos na margem direita, a leste do reservatório, no quadrante nordeste-sul, o acesso à represa é facilitado através das avenidas 23 de Maio, Washington Luís e Interlagos até as pontes do Socorro e de Interlagos e, a partir delas duas vias de acesso à margem direita, as avenidas Teotônio Vilela e a Robert Kennedy.

No final dos anos 80, a ocupação do entorno causava impactos na represa como as florações de algas, resultantes da grande quantidade de matéria orgânica proveniente do despejo de esgotos na água, que causaram entupimentos dos filtros na captação de água, e uma grande mortandade de peixes que ameaçaram o abastecimento de água para 3 milhões de pessoas.

Devido essa situação, o governo estadual iniciou para a região a elaboração de um programa de recuperação ambiental - Programa Guarapiranga - implantado durante a década de 90, com investimentos superiores a US\$300 milhões em redes de esgoto e reurbanização de favelas.

\subsection{Caracterização Física da Bacia do Guarapiranga}

A bacia hidrográfica do Guarapiranga é uma sub-bacia do rio Tietê, localiza-se na porção sudoeste da Região Metropolitana de São Paulo - RMSP, com extensão de uma área de $639 \mathrm{Km}^{2}$ (sendo $26 \mathrm{~km} 2$ de reservatório). Compreende parte do território dos municípios de São Paulo (36,13\%), Embu (6,28\%), Itapecerica da Serra $(23,02 \%)$, Cotia $(3,42 \%)$, São Lourenço da Serra $(1,60 \%)$ e Juquitiba $(1,23 \%)$, e toda área do município de Embu-Guaçu (28,30\%). No caso do Município de São Paulo, trata-se de uma área de $229 \mathrm{~km} 2$, o que representa $36 \%$ da área total da bacia. 


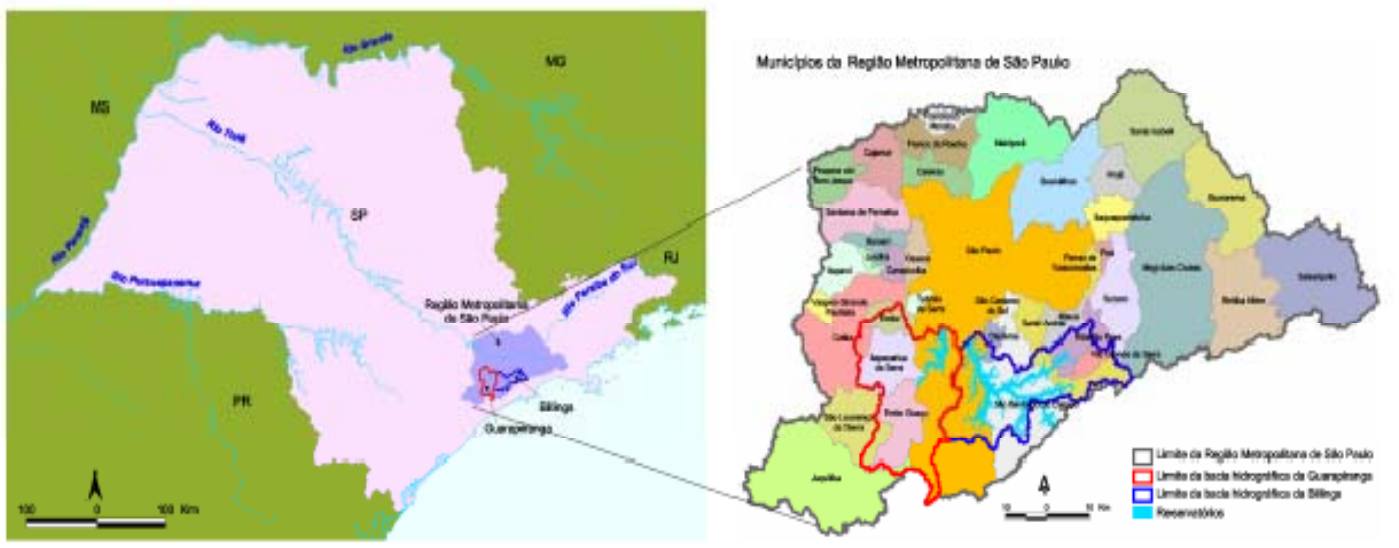

Figura 8 - Localização da Bacia Hidrográfica do Guarapiranga na RMSP

Tabela 15 - Municípios inseridos na bacia da Guarapiranga (em hectares)

\begin{tabular}{|l|c|c|c|c|}
\hline \multicolumn{1}{|c|}{ Municipio/sub-prefeitura } & Área total (1) & Área na Bacia (2) & \% (3) & \% (4) \\
\hline Cotia & 32.589 & 2.262 & 6,9 & 3,5 \\
\hline Embu & 7.008 & 4.057 & 57,9 & 6,3 \\
\hline Embu-Guaçu & 15.504 & 15.511 & 100,0 & 24,3 \\
\hline Itapecerica da Serra & 15.180 & 14.589 & 100,0 & 22,8 \\
\hline Juquitiba & 52.160 & 759 & 1,5 & 1,2 \\
\hline São Lourenço da Serra & 18.671 & 3.310 & 17,7 & 5,2 \\
\hline São Paulo & 152.299 & 23.423 & 15,4 & 36,6 \\
\hline
\end{tabular}

(1) Fonte IBGE

(2) Fonte Sistema de Informações Geográficas ISA (SIG/ISA)

(3) Sobre área total do município

(4) Sobre área total da bacia (63.911 hectares). Fonte: SIG/ISA

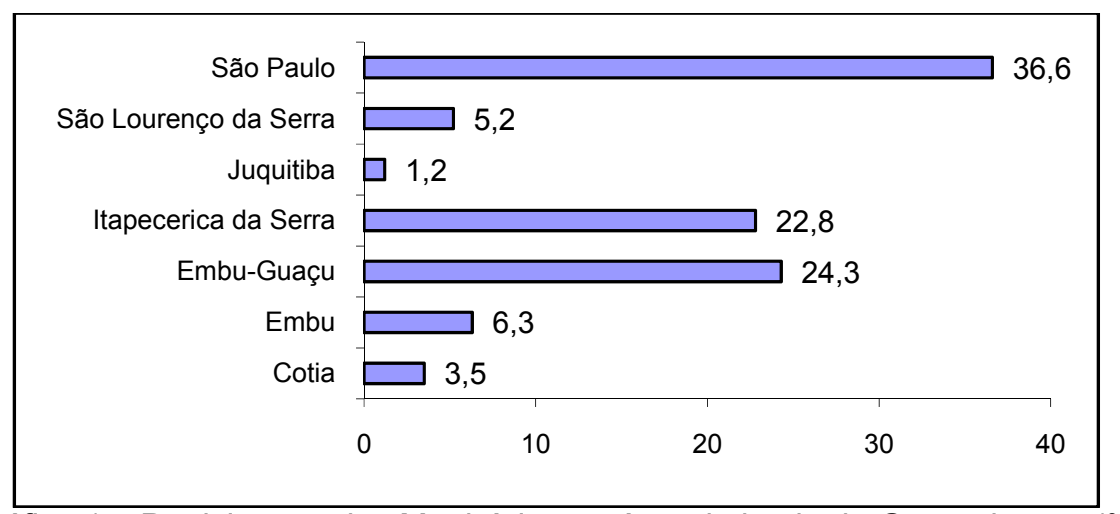

Gráfico 1 - Participação dos Municípios na área da bacia da Guarapiranga (\%) Fonte: SIG/ISA 
Conforme descrito no Relatório Guarapiranga 2005 do Instituto Sócio Ambiental - ISA, a Bacia do Guarapiranga constitui atualmente o segundo maior manancial do sistema de abastecimento da Região Metropolitana de São Paulo (RMSP). A produção média é de 14 mil litros de água por segundo (1,2 bilhões de litros por dia) para atender cerca de 3,7 milhões de habitantes ( $20 \%$ da população da RMSP), residentes nos bairros de Santo Amaro, Campo Limpo, Morumbi e Butantã, todos pertencentes à capital (95\% dos usuários), e em Taboão da Serra (5\%).

Esse sistema inclui a represa e duas transposições de água de outras bacias hidrográficas. Na primeira e mais antiga, o reservatório do Guarapiranga recebe vazões revertidas da bacia do Rio Capivari, situado na vertente marítima, para o Rio EmbuGuaçu, através de bombeamento, da ordem de $1 \mathrm{~m} 3 / \mathrm{s}$. A segunda, em funcionamento desde 2000, é a reversão das águas do Braço Taquacetuba, da represa Billings, para o rio Parelheiros (afluente da margem direita da represa) com a utilização entre $2 \mathrm{~m} 3 / \mathrm{s}$ e $4 \mathrm{~m} 3 / \mathrm{s}$. A represa tem vazão natural estimada em $9 \mathrm{~m} 3 / \mathrm{s}$.

A Represa do Guarapiranga tem como principais contribuintes os rios Embu-Mirim, Embu-Guaçu e Parelheiros, além de diversos córregos e pequenos cursos d'água.

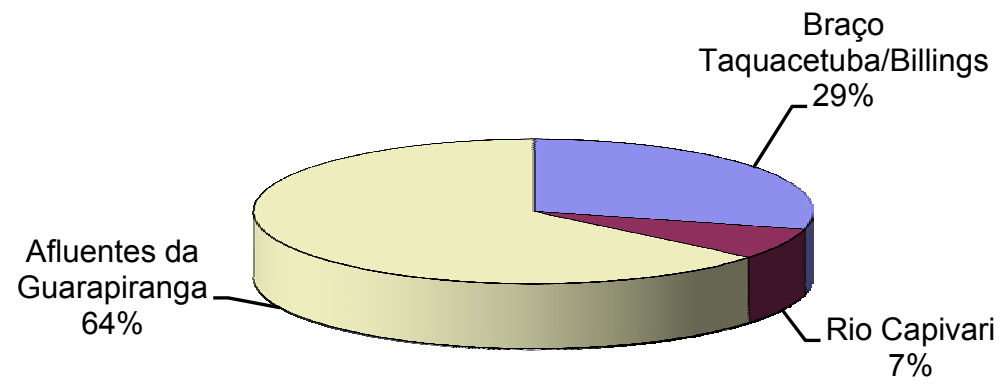

Grafico 2 - Contribuição dos formadores do Sistema Guarapiranga para a produção de água fonte: ISA - Guarapiranga 2005 
Os córregos Guavirutuba e Itupu, na margem esquerda, e os córregos Rio Bonito, das Pedras, São José e Tanquinho, na margem direita, são cursos d'água com pequena contribuição hídrica, porém, representam os principais poluidores, dado que estão situados nas sub-bacias mais densamente ocupadas, com um número acentuado de favelas que se localizam ao longo desses fundos de vale. (França)

A bacia ocupa uma região de transição entre a mancha urbana da metrópole e as escarpas da Serra do Mar ainda recobertas por Mata Atlântica. Incorpora ao norte áreas densamente ocupadas; ao sul territórios ainda preservados, compreendendo as cabeceiras dos rios Embu-Guaçu e Santa Rita, já próximos à vertente marítima da Serra do Mar. A leste confronta-se com a bacia hidrográfica do reservatório Billings, também com alto grau de ocupação urbana e a sudeste, com a bacia do CapivariMonos, ainda pouco ocupada. Ao oeste confronta-se com a bacia do rio Cotia e com a reserva florestal do Morro Grande.

Apresenta altas fragilidades naturais; relevo acidentado; alta densidade de drenagem com inúmeras nascentes, destacando-se como principais formadores o rio Embu Mirim, que drena a região de Cotia, Embu e Itapecerica da Serra, o rio Embu-Guaçu e seu afluente Santa Rita e o Parelheiros que absorvem $30 \%$ das cargas poluidoras afluentes aos cursos d'água. A partir de 1980, eventos de floração de algas tornaram-se freqüentes na represa e chamaram a atenção da sociedade para os problemas do território.

A região compreende terrenos entre 730 e 930 metros de altitude, apresentando um relevo bastante acidentado em quase toda sua extensão. De maneira geral, a bacia pode ser caracterizada pela presença de vertentes escarpadas frágeis à ocupação urbana e também pela presença de extensas planícies aluviais. Apresenta temperaturas médias entre $16^{\circ}$ e $23^{\circ} \mathrm{C}$, índice pluviométrico anual entre 1600 e 2000 milímetros. A direção predominante dos ventos é SW - NE. 
O Instituto de Pesquisas Tecnológicas do Estado de São Paulo (IPT) realizou um estudo de "Aptidão Física ao Assentamento Urbano" que permite avaliar a fragilidade da região quanto à sua capacidade de receber ocupação urbana. Esse estudo baseado em informações sobre variações de relevo, características físicas do solo, tipologia da cobertura vegetal tem como objetivo apresentar orientações para expansão urbana; subsidiar, com critérios técnicos, a elaboração de projetos de parcelamento do solo; minimizar problemas geotécnicos, em especial os relacionados com erosão, assoreamento, enchentes e escorregamento de terra.

Segundo este estudo, 58,4\% da Bacia do Guarapiranga apresenta sérias e severas restrições ao assentamento urbano, 5,1\% condições favoráveis e 26,2\% têm restrições localizadas.

Tabela. 16 - Classes de Aptidão ao Assentamento Urbano

\begin{tabular}{|c|c|c|c|c|}
\hline \multirow{2}{*}{$\begin{array}{l}\text { Classe de } \\
\text { Aptidão }\end{array}$} & \multirow[t]{2}{*}{ Relevo } & \multicolumn{3}{|l|}{ Caracterização Geral } \\
\hline & & Descrição & $\begin{array}{l}\text { Área na } \\
\text { Bacia } \\
\text { (ha) }\end{array}$ & $\%$ \\
\hline $\begin{array}{l}\text { Áreas } \\
\text { Favoráveis }\end{array}$ & $\begin{array}{l}\text { Colinas; predominam } \\
\text { amplitudes de } 40 \mathrm{~m} \text { e } \\
\text { declividades de até } 20 \%\end{array}$ & $\begin{array}{l}\text { Topografia suavizada não exigindo } \\
\text { praticas especiais em projetos de } \\
\text { parcelamento }\end{array}$ & 3267 & 5,1 \\
\hline $\begin{array}{l}\text { Áreas com } \\
\text { Restrições } \\
\text { Localizadas }\end{array}$ & $\begin{array}{l}\text { Morrotes; } \\
\text { predominam } \\
\text { amplitudes de } 60 \mathrm{~m} \text { e } \\
\text { declividades de até } \\
20 \%\end{array}$ & $\begin{array}{l}\text { Condições topográficas } \\
\text { predominantemente favoráveis; } \\
\text { com alguns setores problemáticos } \\
\text { (declividades maiores que } 30 \% \text { e } \\
\text { cabeceiras de drenagem) que } \\
\text { exigem cuidados especiais de } \\
\text { projeto e implantação }\end{array}$ & 17024 & 26,6 \\
\hline $\begin{array}{l}\text { Áreas } \\
\text { Passíveis de } \\
\text { Ocupação } \\
\text { com Sérias } \\
\text { Restrições }\end{array}$ & $\begin{array}{l}\text { Morros Baixos; } \\
\text { predominam amplitudes } \\
\text { de } 100 \mathrm{~m} \text { e declividades } \\
\text { de até } 30 \%\end{array}$ & $\begin{array}{l}\text { Condições topográficas } \\
\text { desfavoráveis em muitos setores } \\
\text { de encosta, que impõe diretrizes } \\
\text { rígidas de projeto e implantação }\end{array}$ & 22100 & 34,6 \\
\hline $\begin{array}{l}\text { Áreas com } \\
\text { Severas } \\
\text { Restrições - } \\
1\end{array}$ & $\begin{array}{l}\text { Planícies Aluviais; } \\
\text { predominam } \\
\text { declividades inferiores a } \\
5 \%\end{array}$ & $\begin{array}{l}\text { Baixa declividade do terreno, pouca } \\
\text { profundidade do lençol freático e } \\
\text { ocorrência de solos com baixa } \\
\text { capacidade de suporte. Sérios } \\
\text { problemas de enchentes e } \\
\text { dificuldades para implantação de } \\
\text { obras de saneamento, edificações e } \\
\text { sistema viário. }\end{array}$ & 9585 & 15 \\
\hline $\begin{array}{l}\text { Áreas com } \\
\text { Severas }\end{array}$ & $\begin{array}{l}\text { Morrotes baixos } \\
\text { isolados em meio a }\end{array}$ & $\begin{array}{l}\text { Topografia problemática (morrotes } \\
\text { isolados que se destacam de uma }\end{array}$ & 362 & 0,6 \\
\hline
\end{tabular}




\begin{tabular}{|c|c|c|c|c|}
\hline $\begin{array}{l}\text { Restrições - } \\
2\end{array}$ & $\begin{array}{l}\text { planícies aluviais; } \\
\text { predominam } \\
\text { amplitudes de } 40 \mathrm{~m} \mathrm{e} \\
\text { declividades maiores } \\
\text { que } 30 \%\end{array}$ & $\begin{array}{l}\text { área relativamente plana e mal } \\
\text { drenada). Os problemas previstos } \\
\text { para as planícies aluviais são } \\
\text { aqueles descritos na classe anterior. } \\
\text { Nos morrotes os problemas estão } \\
\text { associados à implantação de vias de } \\
\text { acesso e lotes. }\end{array}$ & & \\
\hline $\begin{array}{l}\text { Áreas com } \\
\text { Severas } \\
\text { Restrições - } \\
3\end{array}$ & $\begin{array}{l}\text { Morrotes altos; } \\
\text { predominam } \\
\text { amplitudes de } 80 \mathrm{~m} \mathrm{e} \\
\text { declividades entre } \\
30 \% \text { e } 40 \%\end{array}$ & $\begin{array}{l}\text { Declividades acentuadas nas } \\
\text { encostas, que se apresentam } \\
\text { bastante recortadas por linhas de } \\
\text { drenagem natural. Setores } \\
\text { favoráveis limitados aos topos, que } \\
\text { se apresentam isolados e } \\
\text { constituem pequena parcela da } \\
\text { unidade. Tal fato implica em } \\
\text { parcelamento descontínuo, sendo } \\
\text { difícil e onerosa a implantação de } \\
\text { obras de infra-estrutura. }\end{array}$ & 2065 & 3,2 \\
\hline $\begin{array}{l}\text { Áreas com } \\
\text { Severas } \\
\text { Restrições - } \\
4\end{array}$ & $\begin{array}{l}\text { Morros Altos; } \\
\text { predominam amplitudes } \\
\text { de } 150 \mathrm{~m} \text { e declividades } \\
\text { (topos de morros) }\end{array}$ & $\begin{array}{l}\text { Amplitudes e declividades elevadas } \\
\text { dificultando as condições de acesso } \\
\text { às áreas potencialmente ocupáveis } \\
\text { maiores que } 30 \% \text {. }\end{array}$ & 3222 & 5,0 \\
\hline $\begin{array}{l}\text { Áreas } \\
\text { Impróprias }\end{array}$ & $\begin{array}{l}\text { Serras e Escarpas; } \\
\text { predominam amplitudes } \\
\text { de } 300 \mathrm{~m} \text { (serras) e } \\
100 \mathrm{~m} \text { (escarpas) e } \\
\text { declividades maiores } \\
\text { que } 30 \%\end{array}$ & $\begin{array}{l}\text { Amplitudes e declividades elevadas, } \\
\text { e precária estabilidade das encostas } \\
\text { impõem diretrizes rígidas que, na } \\
\text { quase totalidade dos casos, } \\
\text { inviabilizam o parcelamento. }\end{array}$ & & \\
\hline $\begin{array}{l}\text { Área Urbana } \\
\text { Edificada }\end{array}$ & & $\begin{array}{l}\text { Áreas urbanas edificadas anteriores } \\
\text { ao estudo que não foram } \\
\text { classificadas. }\end{array}$ & 2732 & 4,3 \\
\hline Água & & Lagoas e outros cursos d’água & 2701 & 4,2 \\
\hline $\begin{array}{l}\text { Áreas de } \\
\text { Parques ou } \\
\text { Reservas }\end{array}$ & & & 771 & 1,2 \\
\hline
\end{tabular}

\subsection{Caracterização Geral de Uso e Ocupação da Bacia.}

\subsubsection{Legislação Ambiental incidente na Bacia da Guarapiranga}

Na região da Bacia da Guarapiranga incidem normas federais e estaduais relativas à proteção ambiental em geral, à proteção dos recursos hídricos e florestais, ao licenciamento de atividades potencialmente prejudiciais ao meio ambiente, ao uso e ocupação do solo e aos crimes ambientais. 
Tabela 17 - Legislação Ambiental básica aplicável à Bacia da Guarapiranga

\begin{tabular}{|c|c|}
\hline NÚMERO E ANO & ASSUNTO \\
\hline \multicolumn{2}{|l|}{ FEDERAL } \\
\hline Lei $n^{\circ} .4771$ de 1965 & Código Florestal \\
\hline Lei $n^{\circ} .6766$ de 1979 & Parcelamento do solo urbano \\
\hline Lei $n^{\circ} .6902$ de 1981 & $\begin{array}{l}\text { Cria as figuras jurídicas de Estação Ecológica e Área de Proteção } \\
\text { Ambiental - APA }\end{array}$ \\
\hline 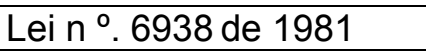 & Dispõe sobre a Política Nacional de Meio Ambiente \\
\hline $\begin{array}{l}\text { Resolução CONAMA nº } \\
1 \text { de1986 }\end{array}$ & Dispõe sobre as atividades minerarias \\
\hline \multirow{2}{*}{$\begin{array}{l}\text { Constituição Federal de } \\
1988 \\
\text { Decreto Federal } n^{\circ} 750 \\
\text { de } 1993\end{array}$} & Capítulo de Meio Ambiente - Artigo 22, 23, 24 e 25 \\
\hline & $\begin{array}{l}\text { Regula o corte, a exploração e a supressão de vegetação primária } \\
\text { ou nos estágios avançado e médio de regeneração da Mata } \\
\text { Atlântica }\end{array}$ \\
\hline $\begin{array}{l}\text { Resolução CONAMA nº } \\
1 \text { de1994 }\end{array}$ & $\begin{array}{l}\text { Regula o corte, a exploração e a supressão de vegetação primária } \\
\text { ou nos estágios avançado e médio de regeneração da Mata } \\
\text { Atlântica no Estado de São Paulo }\end{array}$ \\
\hline Lei $n^{\circ} .9433$ de 1997 & $\begin{array}{l}\text { Institui a Política Nacional de Recursos Hídricos e cria o Sistema } \\
\text { Nacional de Gerenciamento de Recursos Hídricos }\end{array}$ \\
\hline Lei $n^{\circ} .9605$ de 1998 & $\begin{array}{l}\text { Dispõe sobre as sanções penais e administrativas derivadas de } \\
\text { condutas e atividades lesivas ao meio ambiente - "Lei de Crimes } \\
\text { Ambientais" }\end{array}$ \\
\hline $\begin{array}{l}\text { Resolução CNRH no. } 12 \\
\text { de } 2000\end{array}$ & $\begin{array}{l}\text { Define critérios para enquadramento de corpos d’água em classes, } \\
\text { segundo seu uso preponderante }\end{array}$ \\
\hline \multirow{2}{*}{$\begin{array}{l}\text { Resolução CNRH } n^{\circ} .16 \\
\text { de } 2000 \\
\text { Lei } n^{\circ} .9985 \text { de } 2000\end{array}$} & Define regras e critérios para outorga de uso de recursos hídricos \\
\hline & $\begin{array}{l}\text { Institui o Sistema Nacional de Unidades de Conservação (SNUC), } \\
\text { que regulamenta a criação e a gestão das unidades de conservação } \\
\text { em território nacional }\end{array}$ \\
\hline \multirow{2}{*}{$\begin{array}{l}\text { Decreto } \mathrm{n}^{\circ} \cdot 4340 \text { de } \\
2002 \\
\text { Resolução CONAMA n } \\
357 \text { de } 2005\end{array}$} & Regulamenta a Lei $n^{\circ} .9985 / 00$ \\
\hline & $\begin{array}{l}\text { Dispõe sobre a classificação dos corpos de água e diretrizes } \\
\text { ambientais para o seu enquadramento, bem como estabelece as } \\
\text { condições e padrões de lançamento de efluentes, e dá outras } \\
\text { providências }\end{array}$ \\
\hline \multicolumn{2}{|l|}{ ESTADUAL } \\
\hline Lei $n^{\circ} .898$ de 1975 & Proteção aos Mananciais da Região Metropolitana de São Paulo \\
\hline Lei $n^{\circ} .997$ de 1976 & Dispõe sobre o Controle de Poluição do Meio Ambiente \\
\hline Lei $n^{\circ} .1172$ de 1976 & Proteção aos Mananciais da Região Metropolitana de São Paulo \\
\hline Decreto $n^{\circ} 8468$ de 1976 & $\begin{array}{l}\text { Estabelece, dentre outras disposições, as classes de uso da água } \\
\text { no Estado de São Paulo e define os seus respectivos parâmetros de } \\
\text { qualidade }\end{array}$ \\
\hline $\begin{array}{l}\text { Constituição do Estado } \\
\text { de São Paulo de } 1989\end{array}$ & $\begin{array}{l}\text { Artigos do Meio Ambiente, dos Recursos Naturais e do Saneamento } \\
\text { - art. } 191 \text { a } 213\end{array}$ \\
\hline Lei $n^{\circ} .7663$ de 1991 & $\begin{array}{l}\text { Institui a Política e o Sistema Estadual de Gerenciamento de } \\
\text { Recursos Hídricos }\end{array}$ \\
\hline Lei $n^{\circ} .9034$ de 1994 & $\begin{array}{l}\text { Estabelece o primeiro Plano Estadual de Gerenciamento de } \\
\text { Recursos Hídricos }\end{array}$ \\
\hline
\end{tabular}




\begin{tabular}{|c|c|}
\hline $\begin{array}{l}\text { Decreto } n^{\circ} 43505 \text { de } \\
1998\end{array}$ & $\begin{array}{l}\text { Autoriza a Secretaria de Meio Ambiente do Estado de São Paulo a } \\
\text { firmar convênios com os Municípios visando a fiscalização e o } \\
\text { licenciamento ambiental }\end{array}$ \\
\hline Lei $n^{\circ} .9509$ de 1997 & Dispõe sobre a Política Estadual de Meio Ambiente \\
\hline Lei $^{\circ} .9866$ de 1997 & $\begin{array}{l}\text { Estabelece a Lei de Proteção aos Mananciais do Estado de São } \\
\text { Paulo }\end{array}$ \\
\hline Lei $n^{\circ} .10020$ de 1998 & $\begin{array}{l}\text { Autoriza o Poder Executivo a participar da constituição das } \\
\text { Fundações Agências de Bacias Hidrográficas }\end{array}$ \\
\hline Lei $n^{\circ} .12183$ de 2005 & $\begin{array}{l}\text { Dispõe sobre a cobrança pela utilização dos Recursos Hídricos do } \\
\text { domínio do Estado de São Paulo, os procedimentos para fixação } \\
\text { dos seus limites, condicionantes e valores e dá outras providências }\end{array}$ \\
\hline Lei $n^{\circ} .12233$ de 2006 & $\begin{array}{l}\text { Estabelece a área de proteção e recuperação ambiental } \\
\text { Guarapiranga }\end{array}$ \\
\hline \multicolumn{2}{|l|}{ MUNICIPAL } \\
\hline Lei $^{\circ}{ }^{\circ} .1238$ de 2001 & $\begin{array}{l}\text { Dispõe sobre Plano Diretor Estratégico do Município de Itapecerica } \\
\text { da Serra }\end{array}$ \\
\hline Lei $\mathrm{n}^{\circ} .72$ de 2003 & Dispõe sobre Plano Diretor do Município de Embu \\
\hline Lei $n^{\circ} .13885$ de 2004 & $\begin{array}{l}\text { Estabelece normas complementares ao Plano Diretor Estratégico, } \\
\text { institui os Planos Regionais Estratégicos das Subprefeituras, dispõe } \\
\text { sobre o parcelamento, disciplina e ordena o Uso e Ocupação do } \\
\text { Solo do Município de São Paulo }\end{array}$ \\
\hline
\end{tabular}

\subsubsection{Uso do solo}

A despeito de toda legislação de proteção e conhecimento produzido ao longo dos anos sobre os impactos negativos sobre a produção de água para o abastecimento público, o processo de ocupação por atividades humanas continua ocorrendo de forma desordenada (ISA, 2005).

Entre 1989 e 2003, a parcela da Bacia ocupada por atividades humanas aumentou de $57,8 \%$ para $59,3 \%$, em detrimento daquelas cobertas por vegetação remanescente de Mata Atlântica e pelo reservatório. Sendo que, desses $59,3 \%$ do seu território alterado por atividades humanas, $42 \%$ foram com usos antrópicos (atividades agrícolas, campo antrópico, mineração, reflorestamento, solo exposto, indústria e área de lazer); 17\% com usos urbanos de alta e média densidade, ocupação dispersa e condomínio.

Portanto, as principais tendências identificadas no período dizem respeito à substituição de áreas cobertas por vegetação nativa por usos antrópicos (campo antrópico, agricultura, mineração, outros); aumento das áreas ocupadas por usos urbanos; e diminuição da área do reservatório. 
Tabela 18 - Uso do solo entre 1989 e 2003

\begin{tabular}{|c|c|c|c|c|c|c|c|c|}
\hline $\begin{array}{l}\text { Uso do solo na Ba } \\
\text { anos de } 1989 \text { e } 2003\end{array}$ & ia da & Guar & ranga & & $\begin{array}{l}\text { Alterações } \\
\text { do solo na }\end{array}$ & $\begin{array}{l}\text { nas } c \\
\text { acia e }\end{array}$ & $\begin{array}{l}\text { ategorias de } \\
\text { ntre } 1989 \text { e } 2\end{array}$ & $\begin{array}{l}\text { uso } \\
003\end{array}$ \\
\hline $\begin{array}{l}\text { Classe de uso do } \\
\text { solo }\end{array}$ & $\begin{array}{l}\text { Área } \\
\text { (ha) } \\
1989\end{array}$ & $\%$ & $\begin{array}{l}\text { Área } \\
\text { (ha) } \\
2003\end{array}$ & $\%$ & $\begin{array}{r}\text { Conversão } \\
1989 \text { e } 2\end{array}$ & $\begin{array}{l}\text { entre } \\
03\end{array}$ & $\begin{array}{r}\text { Incremento } \\
1989 \text { e } 20\end{array}$ & $\begin{array}{l}\text { entre } \\
03\end{array}$ \\
\hline & & & & & Área (ha) & $\%$ & Área (ha) & $\%$ \\
\hline $\begin{array}{l}\text { Ocupação urbana de } \\
\text { alta densidade }\end{array}$ & 4492 & 7,0 & 4909 & 7,7 & & & 419 & 9,3 \\
\hline $\begin{array}{l}\text { Ocupação urbana de } \\
\text { média densidade }\end{array}$ & 2887 & 4,5 & 3705 & 5,8 & 74 & 2,6 & 889 & 30,8 \\
\hline Ocupação dispersa & 1585 & 2,5 & 1930 & 3,0 & 96 & 6,1 & 441 & 27,9 \\
\hline Condomínio & 246 & 0,4 & 261 & 0,4 & & & 15 & 5,9 \\
\hline Agricultura & 2731 & 4,3 & 2762 & 4,3 & 665 & 24,3 & 696 & 25,5 \\
\hline Campo antrópico & 19433 & 30,4 & 18874 & 29,5 & 2475 & 12,7 & 1916 & 9,9 \\
\hline Estrada & 42 & 0,1 & 42 & 0,1 & & & & \\
\hline Indústria & 179 & 0,3 & 185 & 0,3 & & & 5 & 3 \\
\hline Lazer & 305 & 0,5 & 340 & 0,5 & & & 35 & 11,5 \\
\hline Mineração & 322 & 0,5 & 382 & 0,6 & 62 & 19,2 & 121 & 37,7 \\
\hline Reflorestamento & 4387 & 6,9 & 4198 & 6,6 & 532 & 12,1 & 343 & 7,8 \\
\hline Solo exposto & 338 & 0,5 & 311 & 0,5 & 363 & 107,2 & 335 & 99,1 \\
\hline Campo de altitude & 142 & 0,2 & 142 & 0,2 & & & & \\
\hline Várzea & 1112 & 1,7 & 1412 & 2,2 & 35 & 3,2 & 335 & 30,1 \\
\hline $\begin{array}{l}\text { Mata Atlântica primaria } \\
\text { e secundaria em } \\
\text { estágio avançado de } \\
\text { regeneração }\end{array}$ & 13028 & 20,4 & 12892 & 20,2 & 136 & 1 & & \\
\hline $\begin{array}{l}\text { Mata Atlântica primaria } \\
\text { e secundaria em } \\
\text { estágio inicial e médio } \\
\text { de regeneração }\end{array}$ & 9679 & 15,1 & 9110 & 14,3 & 591 & 6,1 & 23 & 0,2 \\
\hline Água & 225 & 0,4 & 235 & 0,4 & 39 & 17,2 & 48 & 21,5 \\
\hline Reservatório & 2776 & 4,3 & 2222 & 3,5 & 588 & 21,2 & 33 & 1,2 \\
\hline $\begin{array}{l}\text { Áreas ocupadas por } \\
\text { usos urbanos }\end{array}$ & 9210 & 14,41 & 10805 & 16,91 & & & & \\
\hline $\begin{array}{l}\text { Áreas ocupadas por } \\
\text { usos antrópicos }\end{array}$ & 27739 & 43,4 & 27094 & 42,39 & & & & \\
\hline
\end{tabular}




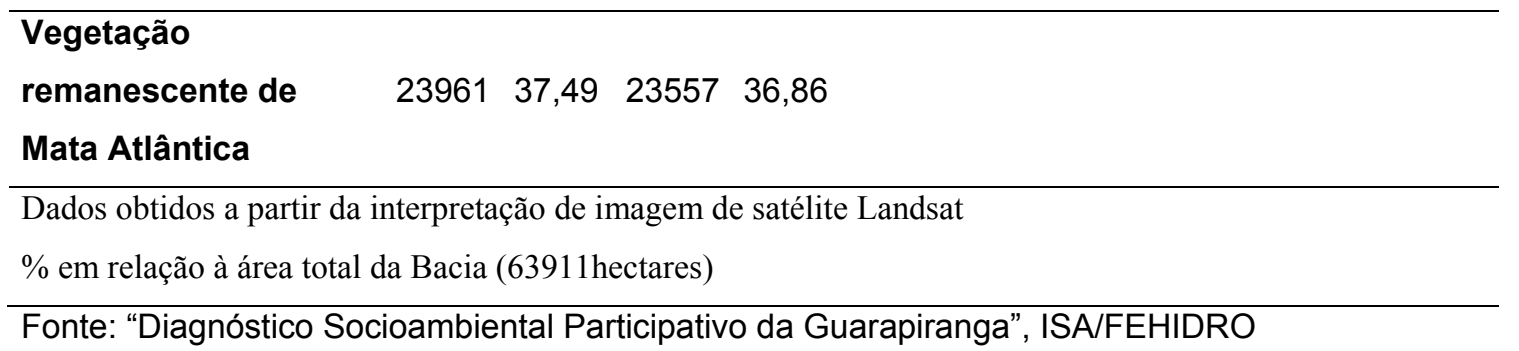

Pelos resultados obtidos no Diagnóstico Socioambiental Participativo, neste período, a Bacia Hidrográfica da Guarapiranga apresentou um crescimento expressivo de áreas de ocupação urbana (19,2\%). Este processo ocorreu através do surgimento de novas ocupações, consolidação da ocupação existente e transformação de áreas rurais em urbanas.

Tabela 19 - Expansão Urbana entre 1989 e 2003

\begin{tabular}{|c|c|c|}
\hline \multicolumn{3}{|c|}{ Expansão urbana na Bacia da Guarapiranga no período de 1989 a 2003} \\
\hline Classe de uso & Incremento (ha) & $\%$ \\
\hline Ocupação urbana de alta densidade & 419 & 9,3 \\
\hline Ocupação urbana de média densidade & 889 & 30,8 \\
\hline Ocupação dispersa e condomínios & 456 & 24,9 \\
\hline $\begin{array}{r}\% \text { em relação à área total da categoria em } 1989 \\
\text { Total }\end{array}$ & 1764 & 19,2 \\
\hline
\end{tabular}

A área ocupada pela represa diminuiu 588 hectares (21,2\%), dos quais 401 hectares dizem respeito à perda no período entre 1999 e 2003, o que pode ser reflexo da estiagem pelo qual a RMSP vem passando desde 1999, mas também pode estar associada à alta taxa de sedimentação de 230.931m3/ano (IPT, 1997) e à exploração do reservatório, além da sua capacidade natural, tendo em vista que $36 \%$ (5 m3/s) da vazão tratada na ETA Alto da Boa Vista é proveniente da transposição de água de outras bacias hidrográficas, Billings (Taquacetuba - $4 \mathrm{~m} 3 / \mathrm{s}$ ) e Capivari (1m3/s). 


\subsubsection{Expansão de áreas urbanas e aptidão física ao assentamento urbano}

A ocupação na Bacia Hidrográfica da Guarapiranga está concentrada em áreas ambientalmente frágeis como o entorno da represa e áreas com restrições físicas para receber ocupação urbana, o que intensifica seus impactos.

Para o período entre 1989 e 2003, verificou-se que apenas 12,4\% da expansão urbana ocorrida foram sobre áreas favoráveis ao assentamento urbano, enquanto $84,5 \%$ sobre áreas com alguma restrição, sendo 55,4\% delas em áreas com sérias restrições.

Tabela 20 - Expansão urbana por categoria de aptidão física ao assentamento urbano

\section{Expansão urbana por Distribuição das áreas}

categoria de aptidão física com usos urbanos em

ao assentamento urbano 2003 nas categorias de

entre 1989 e 2003

aptidão física ao

assentamento urbano

\begin{tabular}{lcccccc}
\hline \multicolumn{1}{c}{ Classes de aptidão } & $\begin{array}{c}\text { Acréscim } \\
\mathbf{0} \mathbf{1 9 8 9 -} \\
\mathbf{2 0 0 3} \mathbf{( h a )}\end{array}$ & $\mathbf{\% ( 1 )}$ & $\mathbf{\%}(\mathbf{2})$ & $\begin{array}{c}\text { Área } \\
\text { (ha) }\end{array}$ & $\mathbf{\% ( 3 )}$ & $\mathbf{\%}(\mathbf{4})$ \\
\hline Áreas favoráveis & 219,1 & 12,4 & 35,5 & 816,5 & 7,6 & 24,99 \\
\hline $\begin{array}{l}\text { Áreas com restrições } \\
\text { localizadas }\end{array}$ & 512,8 & 29,1 & 21,2 & 2870,7 & 26,6 & 16,86 \\
\hline $\begin{array}{l}\text { Áreas com sérias } \\
\text { restrições }\end{array}$ & 667,6 & 37,8 & 26,9 & 3102,9 & 28,7 & 14,04 \\
\hline $\begin{array}{l}\text { Áreas com severas } \\
\text { restrições }\end{array}$ & 310,1 & 17,6 & 26,7 & 1438,7 & 13,3 & 9,44 \\
\hline
\end{tabular}

\begin{tabular}{lcccccc}
\hline Áreas impróprias & - & - & - & 0,6 & 0,0 & 0,78 \\
\hline Áreas não classificadas & 54,5 & 3,1 & 2,2 & 2574,9 & & \\
\hline
\end{tabular}

(1) em relação ao total da expansão urbana no período (1764 hectares)

(2) em relação à área urbana existente em cada categoria em 1989

(3) em relação à área total de usos urbanos em 2003 (10805 hectares)

(4) em relação à área urbana existente em cada categoria em 1989 
Gráfico 3 - Distribuição das áreas urbanas nas categorias de aptidão física no assentamento urbano na Bacia Hidrográfica da Guarapiranga em 2003.

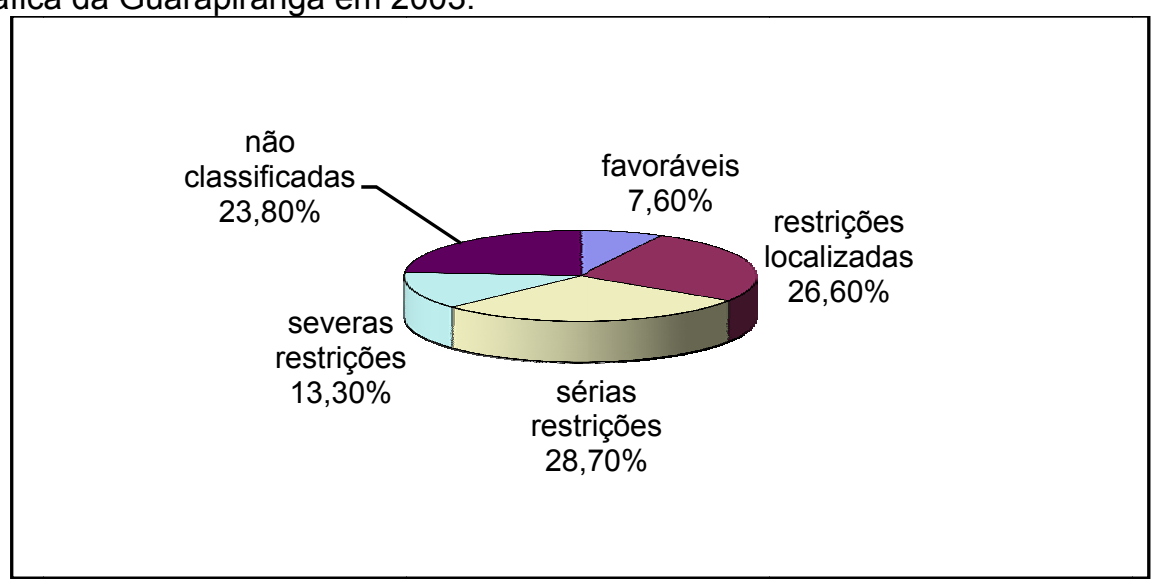

\subsubsection{Crescimento Populacional}

Conforme o Censo Demográfico do IBGE, o crescimento populacional no interior da bacia foi elevado de 332.000 habitantes em 1980; para 556.438 em 1991; para 645.000 em 1996; e para 766.810 em 2000.

O crescimento populacional é um importante indicador para se avaliar as alterações sócio-ambientais em uma bacia hidrográfica utilizada para abastecimento público aliado à ocupação desordenada do território; o aumento da população gera maiores probabilidades de impactos ambientais.

Entre 1991 e 2000, a região recebeu pouco mais de 210 mil novos habitantes, que corresponde a um acréscimo de $37,8 \%$ em relação a 1991. O maior crescimento populacional ocorreu em São Paulo com um aumento de 136,5 mil novos habitantes.

Tabela 21 - Crescimento da População Residente na Bacia, por município, 1991- 2000

\begin{tabular}{lrrrrrr}
\hline Municípios & $\begin{array}{c}\text { Habitantes } \\
1991(1)\end{array}$ & $\begin{array}{l}\text { \% (3) } \\
\text { Cotia }\end{array}$ & $\begin{array}{c}\text { Habitantes } \\
\mathbf{2 0 0 0}(2)\end{array}$ & $\begin{array}{c}\text { \% (3) } \\
\text { Habitantes 1991- }\end{array}$ & \% (4) \\
\hline Embu & 1420 & 0,3 & 1915 & 0,2 & $\mathbf{2 0 0 0}$ & \\
\hline Embu-Guaçu & 43994 & 7,9 & 58595 & 7,6 & 14601 & 34,9 \\
\hline
\end{tabular}




\begin{tabular}{|c|c|c|c|c|c|c|}
\hline Itapecerica & 93146 & 16,7 & 129685 & 16,9 & 36539 & 39,2 \\
\hline Juquitiba & 406 & 0,1 & 1439 & 0,2 & 1033 & 254,4 \\
\hline São Lourenço & 0 & 0 & 472 & 0,1 & 472 & \\
\hline São Paulo & 381195 & 68,5 & 517788 & 67,5 & 136593 & 35,8 \\
\hline Total na Bacia & 556438 & 100 & 766810 & 100 & 210372 & 37,8 \\
\hline \multicolumn{7}{|c|}{$\begin{array}{l}\text { "Censo Demográfico IBGE } 1991 \text { e } 2000 \\
\text { (1) Censo IBGE 1991. Fonte: PDPA Guarapiranga, SRHSO, } 2000 \\
\text { (2) Censo IBGE 2000. Fonte: Base de setores censitários CEM/Cebrap } \\
{ }^{(3)} \text { Em relação à população total residente na Bacia no ano correspondente } \\
{ }^{(4)} \text { Em relação à população residente em 1991, na porção do município inserida na Bacia } \\
\text { (5) O município de São Lourenço da Serra foi criado em 1993, a partir do município de Itapece } \\
\text { Serra }\end{array}$} \\
\hline
\end{tabular}

\subsection{Caracterização dos Índices de Qualidade das Águas na Guarapiranga}

A qualidade das águas que afluem ao reservatório Guarapiranga está diretamente relacionada às características de uso e ocupação do solo dos diferentes compartimentos da bacia, assim como a disponibilidade de infra-estrutura sanitária e seu respectivo nível de eficiência operacional.

Pelo Decreto Estadual n. 8.468 de 1.976, a águas do reservatório Guarapiranga foram enquadradas como sendo de Classe 1, categoria de águas destinadas, entre outros usos, ao abastecimento doméstico após tratamento simplificado e à preservação das comunidades aquáticas, onde não são admitidos lançamentos de efluentes, mesmo tratados. Além do reservatório, foram enquadrados como Classe 1, os rios Embu-Guaçu e Parelheiros. O rio Embu-Mirim teve suas águas classificadas como sendo Classe 2.

A situação atual do reservatório e seus afluentes caracteriza-se pela deterioração progressiva da qualidade das águas, em função do crescente aumento do despejo de esgotos e da poluição difusa, que resulta em grandes aportes de nutrientes, principalmente, Nitrogênio e Fósforo e de coliformes totais (SMA, 2000 em Seminário Guarapiranga 2006). 


\subsubsection{Carga orgânica poluidora doméstica}

A principal pressão dos rios e reservatório continua a ser o lançamento de esgoto doméstico in natura, pois possui matéria orgânica biodegradável, micro-nutrientes, microrganismos e sólidos em suspensão.

Para avaliar a carga de esgoto doméstico, a CETESB apresenta a situação sanitária dos municípios, por meio das porcentagens de coleta e tratamento de esgoto e da carga orgânica potencial e remanescente.

A porcentagem de coleta é definida em função da população urbana atendida por rede coletora de esgoto. A porcentagem de tratamento é aquela da população urbana atendida por rede coletora e que tem seu esgoto tratado. Por meio dos índices de coleta e tratamento é possível estimar a carga orgânica poluidora potencial e remanescente.

A carga orgânica potencial é a quantidade de matéria orgânica gerada pela população urbana por dia. É estimada pela multiplicação da população urbana e a quantidade de matéria orgânica gerada por pessoa por dia. Adota-se o valor de 0,054 kg DBO / dia como a quantidade de matéria orgânica gerada / habitante / dia.

A carga orgânica removida no sistema de tratamento é calculada multiplicando-se a carga potencial pela porcentagem coletada vezes a de tratamento vezes a da eficiência esperada do tratamento. Adotam-se $80 \%$ de eficiência (desde que, a média de todos os sistemas de tratamentos existentes esteja atendendo aos padrões de emissão preconizado no artigo 18 do Regulamento da Lei $n^{\circ}$ 997/76, aprovado pelo Decreto Estadual n 8468/76 e do artigo 34 da Resolução CONAMA 357/05). Para os municípios onde a CETESB dispõe dos dados de vazão e $\mathrm{DBO}_{5,20}$, antes e após o tratamento, a carga remanescente é calculada com base na eficiência real do sistema.

A carga orgânica remanescente é aquela efetivamente lançada em corpos d'água após redução ocorrida nos sistemas de tratamento, sendo calculada como a carga orgânica 
gerada pela população urbana menos a carga orgânica removida no sistema de tratamento de esgoto.

As informações das porcentagens de coleta e tratamento dos esgotos domésticos foram levantadas pelas Agências Ambientais da Diretoria de Controle da Poluição Ambiental.

Tabela 22 - Carga Orgânica Poluidora de origem doméstica segundo os relatórios "Águas Interiores no Estado de São Paulo" (CETESB), no período entre 2000 e 2006.

\begin{tabular}{|c|c|c|c|c|c|c|c|c|}
\hline \multirow{3}{*}{ Município } & \multicolumn{7}{|c|}{ População } & \multirow{3}{*}{ Corpo Receptor } \\
\hline & \multirow[t]{2}{*}{$\begin{array}{l}\text { Conces } \\
\text {-são }\end{array}$} & \multicolumn{2}{|c|}{$\begin{array}{c}\text { *Censo } 2000 \\
\text { **SEADE }\end{array}$} & \multicolumn{2}{|c|}{$\begin{array}{c}\text { Atendimento } \\
\text { (\%) }\end{array}$} & \multicolumn{2}{|c|}{$\begin{array}{c}\text { Carga Poluidora } \\
\text { (kg DBO/dia) }\end{array}$} & \\
\hline & & Total & Urbana & $\begin{array}{c}\text { Cole- } \\
\text { ta }\end{array}$ & $\begin{array}{l}\text { Trata- } \\
\text { mento }\end{array}$ & $\begin{array}{c}\text { Poten- } \\
\text { cial }\end{array}$ & $\begin{array}{c}\text { Remanes } \\
\text {-cente }\end{array}$ & \\
\hline \multirow{9}{*}{ Cotia } & Sahesn & & & & & & & Rios Tietê e \\
\hline & Navesp & & & & & & & Sorocamirim \\
\hline & $2000 *$ & 148082 & 148082 & 35 & 0 & 7996 & 7996 & \\
\hline & $2001 *$ & 148082 & 148082 & 35 & 0 & 7996 & 7996 & \\
\hline & $2002 *$ & 148082 & 148082 & 33 & 0 & 7996 & 7996 & \\
\hline & $2003 *$ & 148082 & 148082 & 33 & 0 & 7996 & 7996 & \\
\hline & $2004 *$ & 148082 & 148082 & 36 & 0 & 7996 & 7996 & \\
\hline & $2005 * *$ & 174555 & 174555 & 36 & 0 & 9426 & 9426 & \\
\hline & $2006 * *$ & 179565 & 179565 & 36 & 0 & 9697 & 9697 & \\
\hline \multirow[t]{8}{*}{ Embu } & Sabesp & & & & & & & \\
\hline & $2000 *$ & 206781 & 206781 & 42 & 0 & 11166 & 11166 & \\
\hline & $2001 *$ & 206781 & 206781 & 42 & 0 & 11166 & 11166 & \\
\hline & $2002 *$ & 206781 & 206781 & 41 & 0 & 11166 & 11166 & \\
\hline & $2003 *$ & 206781 & 206781 & 41 & 0 & 11166 & 11166 & \\
\hline & $2004 *$ & 206781 & 206781 & 41 & 0 & 11166 & 11166 & \\
\hline & $2005 * *$ & 238891 & 238891 & 41 & 0 & 12900 & 12900 & \\
\hline & $2006 * *$ & 244642 & 244642 & 41 & 0 & 13211 & 13211 & \\
\hline Embu- & Sabesp & & & & & & & Rio Embu-Guaçu \\
\hline
\end{tabular}




\begin{tabular}{|c|c|c|c|c|c|c|c|c|}
\hline \multicolumn{9}{|l|}{ Guaçu } \\
\hline & $2000^{*}$ & 56709 & 55631 & 0 & 0 & 3004 & 3004 & \\
\hline & $2001 *$ & 56709 & 55631 & 0 & 0 & 3004 & 3004 & \\
\hline & $2002 *$ & 56709 & 55631 & 21 & 100 & 3004 & 2499 & \\
\hline & $2003^{*}$ & 56709 & 55631 & 21 & 100 & 3004 & 2499 & \\
\hline & $2004 *$ & 56709 & 55631 & 21 & 100 & 3004 & 2499 & \\
\hline & $2005 * *$ & 70461 & 69360 & 21 & 100 & 3745 & 3116 & \\
\hline & $2006 * *$ & 73484 & 72338 & 21 & 100 & 3906 & 3250 & \\
\hline \multirow{8}{*}{$\begin{array}{l}\text { Itapecerica } \\
\text { da Serra }\end{array}$} & Sabesp & & & & & & & Rio Embu Mirim \\
\hline & $2000 *$ & 129156 & 127783 & 3 & 0 & 6900 & 6900 & \\
\hline & $2001 *$ & 129156 & 127783 & 3 & 0 & 6900 & 6900 & \\
\hline & $2002 *$ & 129156 & 127783 & 3 & 0 & 6900 & 6900 & \\
\hline & $2003 *$ & 129156 & 127783 & 3 & 0 & 6900 & 6900 & \\
\hline & $2004 *$ & 129156 & 127783 & 4 & 0 & 6900 & 6900 & \\
\hline & $2005 * *$ & 162448 & 161058 & 4 & 0 & 8697 & 8697 & \\
\hline & $2006 * *$ & 169022 & 167568 & 4 & 0 & 9049 & 9049 & \\
\hline \multirow[t]{8}{*}{ São Paulo } & Sabesp & & & & & & & $\begin{array}{c}\text { Rios Tietê, Pinheiros, } \\
\text { Tamanduateí }\end{array}$ \\
\hline & $2000 *$ & 10406166 & 9785640 & 89 & 46 & 528425 & 355355 & \\
\hline & $2001 *$ & 10406166 & 9785640 & 89 & 46 & 528425 & 355355 & \\
\hline & $2002 *$ & 10406166 & 9785640 & 92 & 67 & 528425 & 267848 & \\
\hline & $2003 *$ & 10406166 & 9785640 & 92 & 67 & 528425 & 267848 & \\
\hline & $2004 *$ & 10406166 & 9785640 & 93 & 66 & 528425 & 268947 & \\
\hline & $2005 * *$ & 10744060 & 9934108 & 93 & 66 & 536442 & 273027 & \\
\hline & $2006 * *$ & 10789058 & 9975563 & 93 & 66 & 538680 & 274167 & \\
\hline
\end{tabular}

A degradação da qualidade da água que ocorre desde a década de 80 , devido ao excessivo lançamento de esgoto doméstico in natura, rico em nutrientes, resultando na crescente floração de algas, caracteriza uma intensa eutrofização da represa, causando impactos sobre o abastecimento, influenciando o processo de tratamento da água, e 
entupindo os filtros das estações. Isso pode ser medido através da quantidade de algicidas aplicados para conter essas florações, bem como a quantidade de produtos químicos utilizados na Estação de Tratamento da Água (ETA) do Alto da Boa Vista, onde o tratamento da água utiliza tecnologias avançadas e com custos crescentes.

\subsubsection{Monitoramento da Qualidade da Água}

A qualidade da água dos rios e tributários é monitorada através das redes operadas pela SABESP e pela CETESB.

A CETESB monitora a bacia em 4 pontos, sendo 2 nos rios Embu-Guaçu (EMGU00800) e Embu-Mirim (EMMI02900) e 2 no reservatório, na captação de água da SABESP (GUA0900) e na foz do rio Parelheiros (GUA0100).

Tabela 23 - Descrição dos Pontos de Amostragem

\begin{tabular}{|c|c|c|}
\hline Pontos & Corpo d’água & Localização \\
\hline EMGU00800 & Embu-Guaçu & Ponte na estrada que liga Embu-Guaçu à Fazenda da Ilha \\
\hline EMMI02900 & Embu-Mirim & Ponte na estrada do M' Boi-Mirim (SP214) \\
\hline \multirow[t]{2}{*}{ GUAR00100 } & Represa & Próximo à foz do rio Parelheiros no bairro do balneário São \\
\hline & Guarapiranga & José \\
\hline \multirow[t]{2}{*}{ GUAR00900* } & Represa & Na captação da Sabesp, junto à casa de bombas \\
\hline & Guarapiranga & \\
\hline BITQ00100 & $\begin{array}{l}\text { Braço do } \\
\text { Taquacetuba }\end{array}$ & $\begin{array}{l}\text { Na baia situada no final da rua Tomekchi Imouye } \\
\text { (captação da Sabesp) }\end{array}$ \\
\hline
\end{tabular}

\subsubsection{Resultados de variáveis de qualidade das águas na Bacia do Guarapiranga.}

Segundo o Relatório "Qualidade das Águas Interiores no Estado de São Paulo" divulgado pela CETESB (2006), para os quatro pontos de monitoramento da Bacia do Guarapiranga mais o ponto do Braço do Taquacetuba na Bacia Billings, obtiveram-se as médias dos resultados para os principais parâmetros de qualidade da água em 2006 comparativos com os últimos dez anos, conforme tabela: 
Tab. 24 - Resultado dos Parâmetros de Qualidade da Água

\begin{tabular}{|c|c|c|c|c|c|c|c|c|c|c|c|c|}
\hline PONTO & 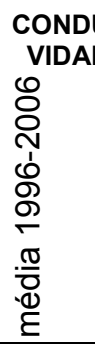 & 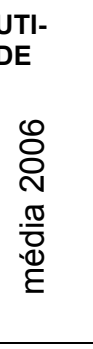 & 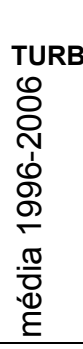 & 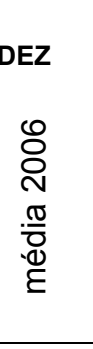 & 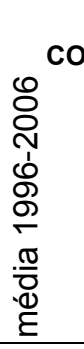 & 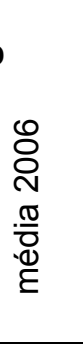 & 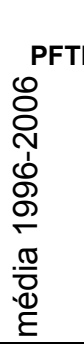 & 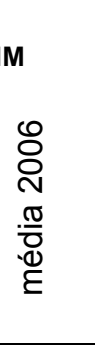 & 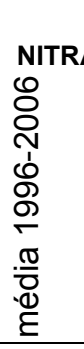 & 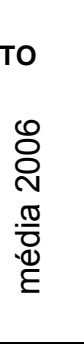 & 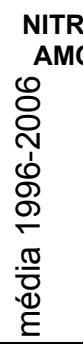 & 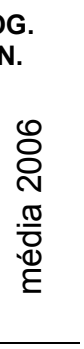 \\
\hline BITQ00100 & 193 & 190 & 15 & 15 & 7,61 & 5,58 & 364 & 450 & 0,38 & 0,22 & 0,11 & 0,06 \\
\hline EMGU00700 & & 38 & & 23 & & & & & & 0,214 & & 0,27 \\
\hline EMGU00800 & 38 & 40 & 19 & 6 & & & & & 0,37 & 0,21 & 0,23 & 0,28 \\
\hline EMMI02900 & 168 & 160 & 13 & 7 & & & & & 1,67 & 0,42 & 1,84 & 2,19 \\
\hline GUAR00100 & 172 & 151 & 6 & 3 & & & & & 0,97 & 0,22 & 0,83 & 1,13 \\
\hline GUAR00900 & 113 & 122 & 3 & 2 & 7,12 & 5,06 & 287 & 349 & 0,76 & 0,34 & 0,20 & 0,07 \\
\hline
\end{tabular}

\begin{tabular}{|c|c|c|c|c|c|c|c|c|c|c|}
\hline \multirow[t]{2}{*}{ PONTO } & \multicolumn{2}{|c|}{ OD } & \multicolumn{2}{|c|}{ DBO5,20 } & \multicolumn{2}{|c|}{ PT } & \multicolumn{2}{|c|}{$\begin{array}{c}\text { COLIFORME } \\
\text { TERM. }\end{array}$} & \multicolumn{2}{|c|}{ CLOROFILA A } \\
\hline & 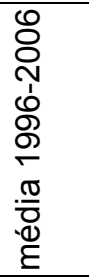 & 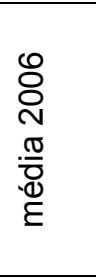 & 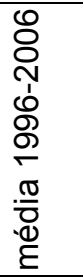 & 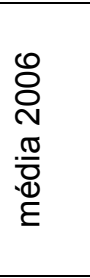 & 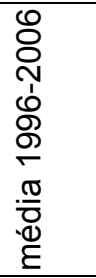 & 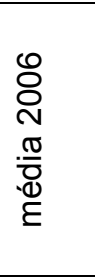 & 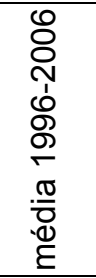 & 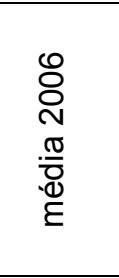 & 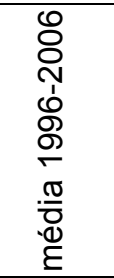 & 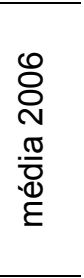 \\
\hline BITQ00100 & 10 & 9,5 & 6 & 4,8 & 0,082 & 0,1371 & $1,50 \mathrm{E}+00$ & $2,20 \mathrm{E}+00$ & 56,21 & 59,77 \\
\hline EMGU00700 & & 6,5 & & 3 & & 0,096 & & $1,60 \mathrm{E}+03$ & & \\
\hline EMGU00800 & 6,3 & 6,4 & 3,2 & 3 & 0,066 & 0,041 & $1,40 \mathrm{E}+03$ & $1,60 \mathrm{E}+03$ & & \\
\hline EMMI02900 & 4,7 & 4,9 & 5,6 & 3,5 & 0,181 & 0,1631 & $1,10 \mathrm{E}+04$ & $1,40 \mathrm{E}+04$ & & \\
\hline GUAR00100 & 4,5 & 5,5 & 5,4 & 4,7 & 0,122 & 0,6481 & $1,20 \mathrm{E}+03$ & $1,70 \mathrm{E}+03$ & 20 & 39,73 \\
\hline GUAR00900 & 7,4 & 9 & 3,6 & 3 & 0,054 & 0,0554 & $4,30 \mathrm{E}+01$ & $8,10 \mathrm{E}+00$ & 21,4 & 28,94 \\
\hline
\end{tabular}

Para metais, toxidade, nutrientes e clorofila a, as porcentagens de resultados não conformes em relação aos padrões de qualidade estabelecidos pela Resolução CONAMA 357/2005, bem como a comparação com as porcentagens de não conformidade dos últimos dez anos nos pontos de monitoramento, estão descritos a seguir: 
Tabela 25 - resultados não conformes em relação aos padrões de qualidade

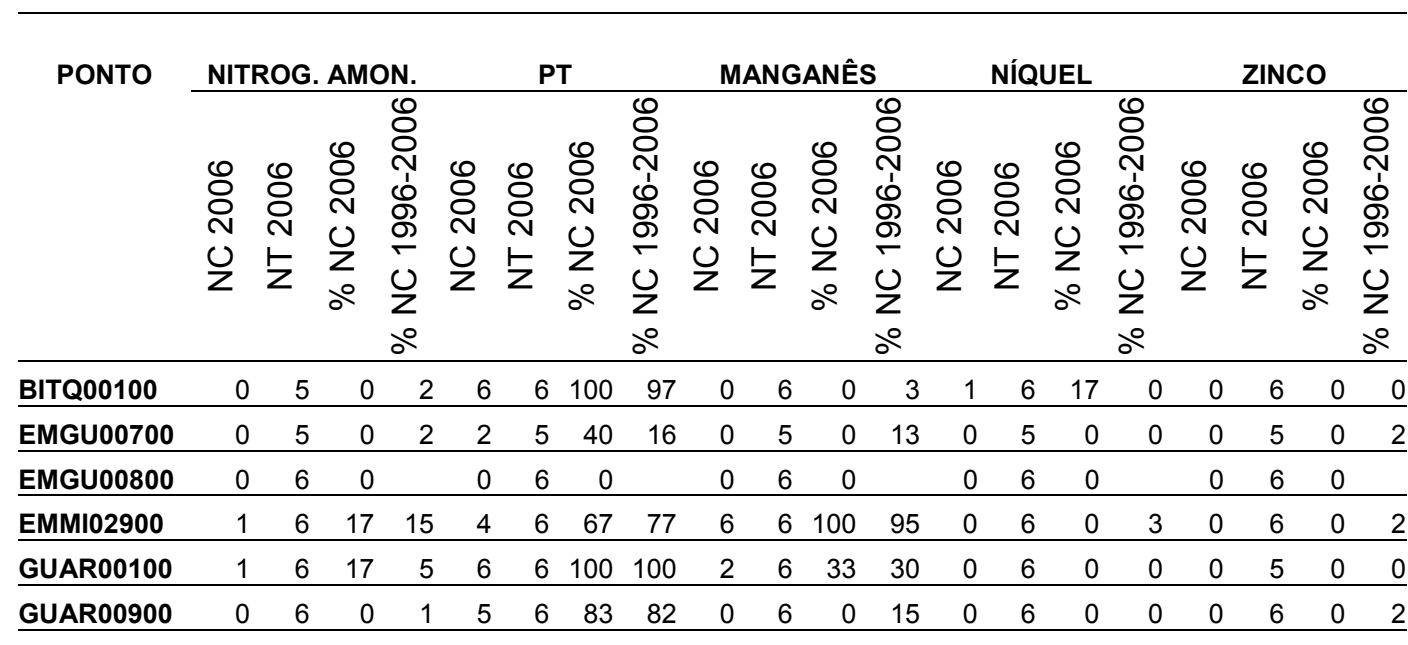

\begin{tabular}{|c|c|c|c|c|c|c|c|c|c|c|c|c|c|c|c|c|}
\hline \multirow[t]{2}{*}{ PONTO } & \multicolumn{4}{|c|}{ TOXIDADE } & \multicolumn{4}{|c|}{ MERCÚRIO } & \multicolumn{4}{|c|}{ CLOROFILA } & \multicolumn{4}{|c|}{$\begin{array}{l}\text { No. CÉLULA } \\
\text { CIANOBACTÉ-RIA }\end{array}$} \\
\hline & $\begin{array}{l}0 \\
\stackrel{O}{ } \\
\text { U } \\
\text { U }\end{array}$ & $\begin{array}{l}\stackrel{\bullet}{\circ} \\
\text { } \\
\text { そ }\end{array}$ & $\begin{array}{l}0 \\
\text { О } \\
ن \\
Z \\
0\end{array}$ & 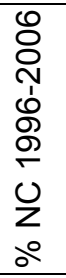 & 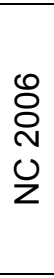 & $\begin{array}{l}\text { ○ } \\
\text { ○ } \\
\text { 上 }\end{array}$ & $\begin{array}{l}0 \\
\text { O } \\
\text { U } \\
\text { U } \\
\text { ○ }\end{array}$ & 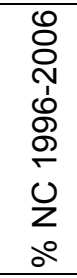 & $\begin{array}{l}\varrho \\
\stackrel{\bigcirc}{ } \\
\text { N } \\
\text { Z }\end{array}$ & $\begin{array}{l}\text { ○ } \\
\text { N } \\
\text { Z }\end{array}$ & $\begin{array}{l}0 \\
8 \\
\text { N } \\
0 \\
Z \\
\text { ○ீ }\end{array}$ & 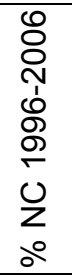 & $\begin{array}{l}\varrho \\
\stackrel{\bigcirc}{ } \\
\stackrel{N}{ } \\
\cup \\
Z\end{array}$ & 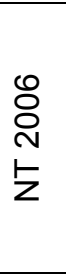 & 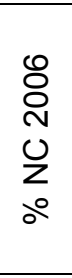 & 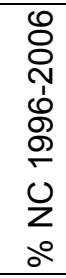 \\
\hline BITQ00100 & & 6 & $\begin{array}{ll}6 & 100 \\
\end{array}$ & 71 & 0 & 6 & 0 & $\begin{array}{ll}0 & 19 \\
\end{array}$ & 6 & 6 & $6 \quad 100$ & 100 & 6 & 6 & 100 & 100 \\
\hline EMGU00700 & & 3 & $5 \quad 60$ & 11 & 0 & 5 & 0 & $\begin{array}{ll}0 & 17 \\
\end{array}$ & & & & & & & & \\
\hline EMGU00800 & & 3 & $6 \quad 50$ & & 0 & 0 & 0 & 0 & & & & & & & & \\
\hline EMMI02900 & & 0 & 0 & 2 & $\underline{0}$ & 6 & $\underline{0}$ & 24 & & & & & & & & \\
\hline GUAR00100 & 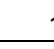 & 1 & $\begin{array}{ll}6 & 17 \\
\end{array}$ & 8 & 0 & $\underline{\epsilon}$ & 0 & $\begin{array}{ll}0 \quad 25 \\
\end{array}$ & 6 & 6 & $6 \quad 100$ & 78 & 3 & 6 & 50 & 94 \\
\hline GUAR00900 & & 0 & 0 & 20 & 0 & 6 & 6 & 8 & 6 & 6 & 6100 & 73 & 32 & 6 & 33 & $3 \quad 61$ \\
\hline
\end{tabular}

A SABESP monitora a qualidade da água da Bacia da Guarapiranga em um total de 30 pontos de amostragem, sendo 20 em rios e tributários, e 10 no reservatório. Para os resultados obtidos no período de 1988 a 2002, foram analisadas as médias anuais de 11 pontos, todos de rios e tributários. Foram analisadas as concentrações máximas, mínimas e as médias aritméticas para cada um dos parâmetros DQO (Demanda Química de Oxigênio), $\mathrm{P}$ total (fósforo total) e $\mathrm{N}$ total (nitrogênio total), em cada um dos pontos.

Para o período entre 1988 e 2002, obtivemos os dados de concentrações máxima, mínima e média de cada um desses parâmetros $(\mathrm{mg} / \mathrm{l})$ de qualidade da água, nos 
pontos de monitoramento da SABESP, podendo diagnosticar as causas pontuais para essas condições.

Tabela 26 - Resultados dos Limites de Concentração de Parâmetros

\begin{tabular}{|c|c|c|c|c|c|c|}
\hline $\begin{array}{l}\text { Pontos de } \\
\text { Monitoramen } \\
\text {-to SABESP }\end{array}$ & Tributário & $\begin{array}{l}\text { Parâme- } \\
\text { tro }\end{array}$ & $\begin{array}{l}\text { Mínim } \\
\text { o } \\
(\mathrm{mg} / \mathrm{l})\end{array}$ & $\begin{array}{l}\text { Máxim } \\
\text { o } \\
(\mathrm{mg} / \mathrm{l})\end{array}$ & $\begin{array}{l}\text { Médi } \\
\text { a } \\
(\mathrm{mg} / 1 \\
)\end{array}$ & Diagnóstico \\
\hline \multirow{3}{*}{ GU-209 } & \multirow{2}{*}{$\begin{array}{l}\text { Córrego } 2 \\
\text { Av. } \\
\text { Rob.Kennedy }\end{array}$} & P total & 0,029 & 0,405 & 0,143 & \multirow{3}{*}{$\begin{array}{l}\text { Concentrações mais } \\
\text { baixas devido a EEE } \\
\text { onde grande parte do } \\
\text { esgoto gerado é } \\
\text { transportado para fora da } \\
\text { bacia }\end{array}$} \\
\hline & & $\mathrm{N}$ total & 0,00 & 9,31 & 5,47 & \\
\hline & /Av.Alcindo & DQO & 3,04 & 59,46 & 18,78 & \\
\hline \multirow{3}{*}{ GU-210 } & \multirow{3}{*}{$\begin{array}{l}\text { Rio Bonito } \\
+ \text { Rio das } \\
\text { Pedras } \\
\end{array}$} & P total & 0,901 & 7,764 & 2,785 & \multirow{3}{*}{$\begin{array}{l}\text { Concentrações elevadas } \\
\text { devido ao tipo de uso } \\
\text { e ocupação do solo com } \\
\text { alta densidade de } \\
\text { Urbanização }\end{array}$} \\
\hline & & $\mathrm{N}$ total & 0,00 & 32,4 & 17,05 & \\
\hline & & DQO & 61,88 & 285,07 & 130,7 & \\
\hline \multirow{3}{*}{ GU-211 } & \multirow{3}{*}{$\begin{array}{l}\text { Córrego } \\
\text { São José }\end{array}$} & P total & 1,766 & 11,034 & 3,953 & \multirow{3}{*}{$\begin{array}{l}\text { Concentrações elevadas } \\
\text { devido ao tipo de uso } \\
\text { e ocupação do solo com } \\
\text { alta densidade de } \\
\text { Urbanização }\end{array}$} \\
\hline & & $\mathrm{N}$ total & 0,00 & 33,04 & 19,30 & \\
\hline & & DQO & 53,27 & 324,59 & 168,5 & \\
\hline \multirow{3}{*}{ GU-212 } & \multirow{3}{*}{$\begin{array}{l}\text { Córrego } \\
\text { Tanquinho }\end{array}$} & $P$ total & 0,890 & 10,123 & 3,856 & \multirow{3}{*}{$\begin{array}{l}\text { Concentrações elevadas } \\
\text { devido ao tipo de uso } \\
\text { e ocupação do solo com } \\
\text { alta densidade de } \\
\text { Urbanização }\end{array}$} \\
\hline & & $\mathrm{N}$ total & 9,84 & 38,89 & 23,31 & \\
\hline & & DQO & 66,18 & 254,12 & $\begin{array}{l}174,5 \\
3\end{array}$ & \\
\hline \multirow{3}{*}{ GU-213 } & \multirow{3}{*}{$\begin{array}{l}\text { Rio } \\
\text { Parelheiros }\end{array}$} & P total & 0,070 & 0,144 & 0,113 & \multirow{3}{*}{$\begin{array}{l}\text { Concentrações } \\
\text { moderadas, pois é um } \\
\text { corpo d`água bastante } \\
\text { - volumoso possibilitando } \\
\text { a diluição dos nutrientes }\end{array}$} \\
\hline & & $\mathrm{N}$ total & 0,50 & 2,79 & 1,48 & \\
\hline & & DQO & 3,33 & 24,10 & 15,72 & \\
\hline
\end{tabular}


continuação

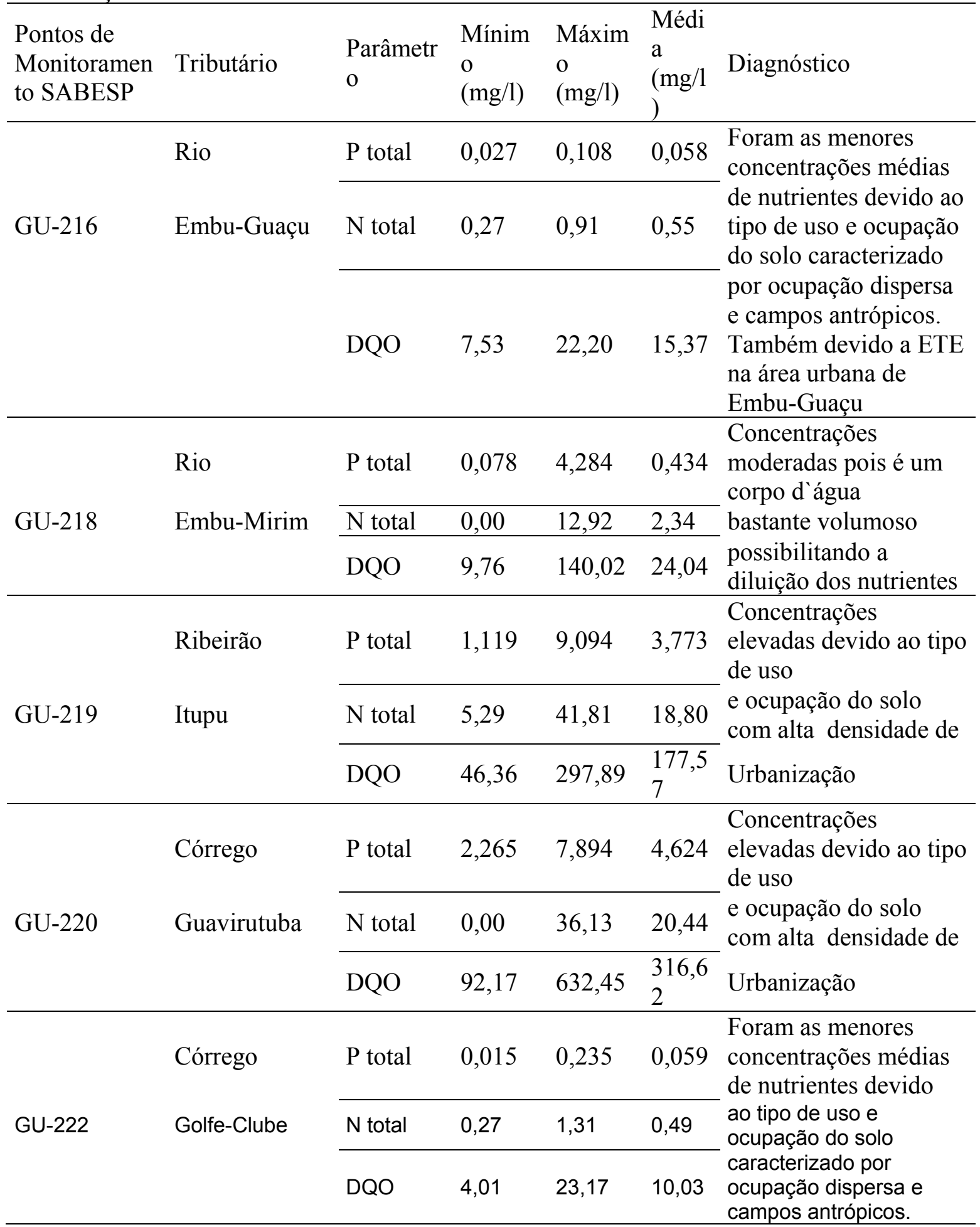

Fonte: Seminário Guarapiranga 2006, apresentado com base nos resultados do "Diagnóstico

Socioambiental Participativo da Guarapiranga", ISA/FEHIDRO 
Todos os pontos da rede de monitoramento da SABESP, com exceção do ponto GU222, apresentaram em todos os anos (de 1988 a 2002), concentrações médias de $P$ total acima do limite de $0,025 \mathrm{mg} / \mathrm{l}$ permitido para a Classe 1 .

O esgoto doméstico produzido na região é responsável por grande parte da poluição dos corpos d'água e da represa. Conforme relatado no Seminário Guarapiranga 2006, em tempo seco corresponde a $96 \%$ da carga de fósforo total afluente ao reservatório. Em eventos de chuva, a participação das cargas difusas rurais e urbanas aumenta consideravelmente, chegando a $58 \%$ da carga de fósforo total produzida na Bacia. $O$ fósforo é considerado fator limitante para o crescimento das algas, responsáveis por impactos na qualidade da água da represa.

Para o estudo desenvolvido pelo ISA em seu "Diagnóstico Socioambiental Participativo - Guarapiranga 2005", nos resultados do período de 1989 a 2004, foram utilizados dados bimestrais referentes às concentrações de fósforo total, coliformes fecais, ph, DBO (Demanda Bioquímica de Oxigênio), OD (Oxigênio Dissolvido), nitrogênio amoniacal, turbidez, ferro total e IQA (Índice de Qualidade da Água) (CETESB, 2005).

Nesse mesmo estudo, para os dados obtidos nos pontos de monitoramento da CETESB, temos a síntese da evolução da qualidade da água, entre 1989 e 2004.

Tabela27 - Diagnóstico dos resultados

Pontos

Diagnóstico

\section{Cetesb}

Foz do Rio Elevado aporte de esgotos domésticos pelo rio Parelheiros contribuem Parelheiros para as altas concentrações de fósforo total, coliformes fecais e baixas (GUA0100) - concentrações de OD verificadas. Por ser um ambiente lêntico (ou reservatório intermediário) impede uma melhor circulação das águas, diminuindo ainda mais a concentração de OD. Por outro lado, consegue diluir mais os nutrientes aportados e assim conferir qualidade BOA ao IQA. Em 11 das 36 amostras o IQA foi regular e em 1, ÓTIMA. Não houve 


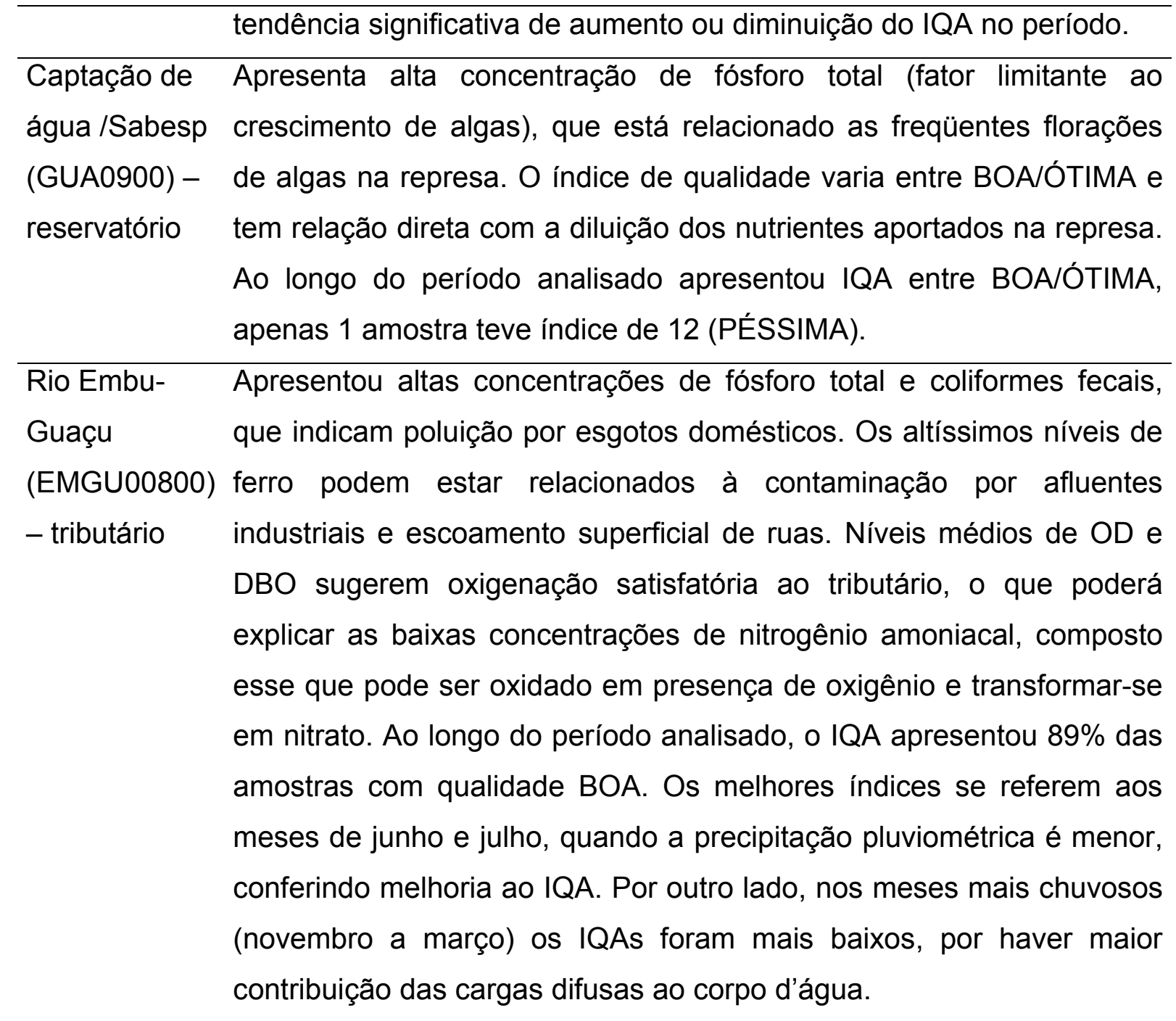

Rio Embu- Foram identificados altos níveis de fósforo total e coliformes fecais, Mirim que estão relacionados com poluição por esgotos domésticos. As (EMMI02900) altíssimas concentrações de ferro indicam possível contribuição por - tributário afluentes industriais. Os níveis baixos de oxigenação, devido ao seu consumo pela decomposição de matéria orgânica (esgoto), permitiu maior concentração de nitrogênio amoniacal, principalmente a partir de 1995, concomitante com a diminuição do IQA. Até 1994 este tributário apresentava qualidade BOA. No período compreendido entre 1994 e 1996, houve queda no IQA conferindo qualidade REGULAR, que se manteve, com oscilações, nos anos seguintes. 


\subsubsection{Cálculo dos Índices de Qualidade da Água para a Bacia do Guarapiranga no período entre 2000 e 2006.}

\subsubsection{IAP e IQA}

Os resultados do IAP - Índice de Qualidade das águas para fins de abastecimento Público e IQA - Índice de Qualidade das águas foram obtidos através das informações contidas nos relatórios "Águas Interiores" (CETESB) do período entre 2000 e 2006, extraindo-se as informações relativas à Bacia do Guarapiranga e Braço do Taquacetuba na Billings.

Para cada ponto do monitoramento da Cetesb os testes foram realizados bimestralmente e obtidos resultados de médias anuais.

Tabela 28 - Média Anual do IAP no período entre 2000 e 2006

\begin{tabular}{|c|c|c|c|c|c|c|c|c|}
\hline Ponto & Corpo d`água & $\begin{array}{c}\text { Média } \\
2000\end{array}$ & $\begin{array}{c}\text { Média } \\
2001\end{array}$ & $\begin{array}{c}\text { Média } \\
2002\end{array}$ & $\begin{array}{c}\text { Média } \\
2003\end{array}$ & $\begin{array}{c}\text { Média } \\
2004\end{array}$ & $\begin{array}{c}\text { Média } \\
2005\end{array}$ & $\begin{array}{c}\text { Média } \\
2006\end{array}$ \\
\hline EMGU00700 & Rio Embu-Guaçu & & & & & & & 60 \\
\hline EMGU00800 & Rio Embu-Guaçu & & & 53 & 66 & 58 & 54 & 61 \\
\hline EMMI02900 & Rio Embu-Mirim & & & 38 & 48 & 50 & 41 & 47 \\
\hline \multirow[t]{2}{*}{ GUAR00100 } & Reservatório & & & 51 & 54 & 51 & 68 & 50 \\
\hline & Guarapiranga & & & & & & & \\
\hline \multirow[t]{2}{*}{ GUAR00900 } & Reservatório & & & 60 & 65 & 46 & 58 & 54 \\
\hline & Guarapiranga & & & & & & & \\
\hline \multirow[t]{2}{*}{ BITQ00100 } & Braço & & & 32 & 42 & 37 & 59 & 25 \\
\hline & Taquacetuba & & & & & & & \\
\hline
\end{tabular}

Tabela 29 - Média Anual do IQA no período entre 2000 e 2006

\begin{tabular}{|c|c|c|c|c|c|c|c|c|}
\hline Ponto & Corpo d`água & $\begin{array}{c}\text { Média } \\
2000\end{array}$ & $\begin{array}{c}\text { Média } \\
2001\end{array}$ & $\begin{array}{c}\text { Média } \\
2002\end{array}$ & $\begin{array}{c}\text { Média } \\
2003\end{array}$ & $\begin{array}{c}\text { Média } \\
2004\end{array}$ & $\begin{array}{c}\text { Média } \\
2005\end{array}$ & $\begin{array}{c}\text { Média } \\
2006\end{array}$ \\
\hline EMGU00700 & Rio Embu-Guaçu & & & & & & & 63 \\
\hline EMGU00800 & Rio Embu-Guaçu & 67 & 59 & 59 & 69 & 64 & 62 & 66 \\
\hline EMMI02900 & Rio Embu-Mirim & 51 & 53 & 47 & 55 & 57 & 47 & 52 \\
\hline GUAR00100 & $\begin{array}{l}\text { Reservatório } \\
\text { Guarapiranga }\end{array}$ & 58 & 58 & 54 & 55 & 53 & 69 & 58 \\
\hline GUAR00900 & $\begin{array}{l}\text { Reservatório } \\
\text { Guarapiranga }\end{array}$ & 68 & 74 & 76 & 75 & 72 & 74 & 82 \\
\hline BITQ00100 & $\begin{array}{c}\text { Braço } \\
\text { Taquacetuba }\end{array}$ & 69 & 71 & 77 & 73 & 72 & 76 & 76 \\
\hline
\end{tabular}




\subsubsection{IVA e IET}

Os resultados do IVA - Índice de Qualidade das Águas para proteção da Vida Aquática e IET - Índice de Estado Trófico das Águas foram obtidos através das informações contidas nos relatórios "Águas Interiores" (CETESB) do período entre 2000 e 20006, extraindo-se as informações relativas à Bacia do Guarapiranga e Braço do Taquacetuba na Billings.

Para cada ponto do monitoramento da Cetesb os testes foram realizados bimestralmente e obtidos resultados de médias anuais.

Tabela 30 - Média Anual do IVA no período entre 2000 e 2006

\begin{tabular}{|c|c|c|c|c|c|c|c|c|}
\hline Ponto & Corpo d’água & $\begin{array}{c}\text { Média } \\
2000\end{array}$ & $\begin{array}{c}\text { Média } \\
2001\end{array}$ & $\begin{array}{c}\text { Média } \\
2002\end{array}$ & $\begin{array}{c}\text { Média } \\
2003\end{array}$ & $\begin{array}{c}\text { Média } \\
2004\end{array}$ & $\begin{array}{c}\text { Média } \\
2005\end{array}$ & $\begin{array}{c}\text { Média } \\
2006\end{array}$ \\
\hline EMGU00700 & Rio Embu-Guaçu & & & & & & & 4,2 \\
\hline EMGU00800 & Rio Embu-Guaçu & & & 4,3 & 4,1 & 4,3 & 2,9 & 3,7 \\
\hline EMMI02900 & Rio Embu-Mirim & & & 6,3 & 5,7 & 5,3 & 5,7 & 4,9 \\
\hline \multirow[t]{2}{*}{ GUAR00100 } & Reservatório & & & 6,2 & 5,8 & 5,2 & 6,0 & 5,8 \\
\hline & Guarapiranga & & & & & & & \\
\hline \multirow[t]{2}{*}{ GUAR00900 } & Reservatório & & & 4,3 & 4,2 & 5,2 & 4,5 & 4,0 \\
\hline & Guarapiranga & & & & & & & \\
\hline \multirow[t]{2}{*}{ BITQ00100 } & Braço & & & 5,6 & 5,4 & 5,4 & 6,5 & 6,2 \\
\hline & Taquacetuba & & & & & & & \\
\hline
\end{tabular}

Tabela 31 - Média Anual do IET no período entre 2000 e 2006

\begin{tabular}{|c|c|c|c|c|c|c|c|c|}
\hline Ponto & Corpo d’água & $\begin{array}{c}\text { Média } \\
2000\end{array}$ & $\begin{array}{c}\text { Média } \\
2001\end{array}$ & $\begin{array}{c}\text { Média } \\
2002 \\
\end{array}$ & $\begin{array}{c}\text { Média } \\
2003\end{array}$ & $\begin{array}{c}\text { Média } \\
2004\end{array}$ & $\begin{array}{c}\text { Média } \\
2005\end{array}$ & $\begin{array}{c}\text { Média } \\
2006\end{array}$ \\
\hline EMGU00700 & Rio Embu-Guaçu & & & & & & & 55 \\
\hline EMGU00800 & Rio Embu-Guaçu & & & 59 & 58,81 & 57,76 & 54 & 53 \\
\hline EMMI02900 & Rio Embu-Mirim & & & 74 & 77,48 & 69,38 & 62 & 59 \\
\hline \multirow[t]{2}{*}{ GUAR00100 } & Reservatório & & & 65 & 63,25 & 64,26 & 60 & 65 \\
\hline & Guarapiranga & & & & & & & \\
\hline \multirow[t]{2}{*}{ GUAR00900 } & Reservatório & & & 58 & 62,84 & 57,49 & 59 & 60 \\
\hline & Guarapiranga & & & & & & & \\
\hline \multirow[t]{2}{*}{ BITQ00100 } & Braço & & & 65 & 67,82 & 62,67 & 62 & 65 \\
\hline & Taquacetuba & & & & & & & \\
\hline
\end{tabular}




\subsection{Análise entre Evolução do Uso do Solo e Qualidade da Água}

\subsubsection{Cálculo do Índice de Comprometimento da Produção Hídrica - ICPH}

Para o diagnóstico da correlação entre as análises da qualidade da água, evolução do uso do solo e áreas mais críticas ou mais sensíveis, o procedimento de monitoramento ambiental descrito no "Diagnóstico Socioambiental Participativo da Guarapiranga", foi dividir a bacia em 23 sub-bacias, sendo 15 do lado esquerdo do rio Embu-Guaçu e Reservatório (GLE) e 8 do lado direito do rio Embu-Guaçu e Reservatório (GLD).

Através da análise integrada entre as características naturais das sub-bacias, tais como relevo, formato, quantidade de nascentes, quantidade de cobertura vegetal e de ocupação por atividades humanas, e as alterações decorrentes de atividades humanas em um determinado período de tempo, foi desenvolvido um indicador que é o "Índice de Comprometimento da Produção Hídrica" - ICPH (ISA, 2002).

Para o cálculo do ICPH são utilizados dados provenientes de interpretações de imagens orbitais e de cartas topográficas digitais. $\mathrm{O}$ indicador baseia-se em modelo algébrico que integra grupos de variáveis geográficas das sub-bacias, traduzidos nos seguintes coeficientes:

- Índice de Escoamento Fluvial, que compreende características naturais, tais como densidade de nascentes, grau de permeabilidade natural, declividade e energia potencial, responsáveis pela velocidade de escoamento da água em direção às represas - e a forma de cada sub-bacia - que influenciará a concentração e dispersão das águas e sedimentos ao longo da área drenada pelos cursos d'água. Este índice identifica o grau de predisposição natural de cada sub-bacia à instabilidade no equilíbrio entre chuva-vazão fluvial, que poderá ser agravado em função do padrão e da intensidade da ocupação antrópica.

- Coeficiente de Cobertura Vegetal, que considera a densidade de vegetação existente em uma determinada região. Quanto maior o índice de vegetação, maior 
a capacidade de retenção de água das chuvas, de infiltração no solo e diminuição da carga de sedimentos transportada pelos cursos d'água.

- Coeficiente de Antropização, que está diretamente ligado com as atividades humanas existentes na Bacia. Considera as densidades de áreas urbanas e usos antrópicos. Um alto valor de coeficiente de antropização significa que grandes quantidades de áreas estão impermeabilizadas e, conseqüentemente, maiores serão as possibilidades de ocorrência de enchentes e concentração de poluição, em especial a poluição difusa que é resultante de poluentes domésticos, agrícolas, e industriais nas sub-bacias.

Com estes indicadores é possível calcular o ICPH das sub-bacias que compõem a Bacia Hidrográfica da Guarapiranga, identificando as mais frágeis ambientalmente ou que sofreram os impactos resultantes das alterações de uso do solo em determinado período.

O ICPH é obtido a partir da equação:

$\mathrm{ICPH}=(3 \mathrm{x}$ (coef. Antr. - coef. Veg.)/(coef. Antr. + coef. Veg.) + 0,3 x índice Esc.Fluv.

Os resultados do ICPH, para cada sub-bacia foram obtidos para o período entre 1989 e 2003 (ISA, 2006) e identificam as mais frágeis ambientalmente e as que sofreram impactos devido às alterações de uso do solo

Tabela 32 - Índice de Comprometimento da Produção Hídrica (ICPH) por sub-bacias da Bacia Hidrográfica da Guarapiranga, no período de 1989 a 2003.

\begin{tabular}{|c|c|c|c|c|c|c|c|c|c|c|c|c|}
\hline $\begin{array}{c}\text { Sub- } \\
\text { bacia }\end{array}$ & $\begin{array}{c}\text { Área } \\
\text { (ha) }\end{array}$ & $\begin{array}{c}\text { Coef. } \\
\text { Antr. }\end{array}$ & $\begin{array}{c}\text { Coef. } \\
\text { Antr. }\end{array}$ & $\Delta \%$ & $\begin{array}{c}\text { Coef. } \\
\text { Veg. }\end{array}$ & $\begin{array}{c}\text { Coef. } \\
\text { Veg. }\end{array}$ & $\Delta \%$ & $\begin{array}{c}\text { Esc. } \\
\text { Fluvi- }\end{array}$ & $\begin{array}{c}\text { ICPH } \\
1989\end{array}$ & $\begin{array}{c}\text { ICPH } \\
2003\end{array}$ & $\begin{array}{c}\text { Taxa } \\
\text { cresci- } \\
\text { mento } \\
\%\end{array}$ & $\begin{array}{c}\text { Diag- } \\
\text { nós- } \\
\text { tico }\end{array}$ \\
\hline
\end{tabular}




\begin{tabular}{|l|l|l|l|l|l|l|l|l|l|l|l|c|}
\hline GLD1 & 2,782 & 2,12 & 2,14 & 1,01 & 0,09 & 0,10 & 1,12 & 0,71 & 2,96 & 2,94 & $-0,88$ & $(1)$ \\
\hline GLD2 & 1,733 & 0,18 & 0,21 & 1,13 & 1,17 & 1,22 & 1,04 & 1,63 & $-1,70$ & $-1,64$ & 3,75 & \\
\hline GLD3 & 1,299 & 0,07 & 0,10 & 1,52 & 1,26 & 1,25 & 0,99 & 1,78 & $-2,16$ & $-2,00$ & 7,04 & \\
\hline GLD4 & 1,428 & 0,17 & 0,19 & 1,08 & 1,33 & 1,36 & 1,02 & 1,48 & $-1,87$ & $-1,83$ & 1,96 & \\
\hline GLD5 & 3,572 & 0,31 & 0,44 & 1,43 & 0,70 & 0,69 & 1,00 & 2,08 & $-0,53$ & $-0,04$ & 91,92 & $(2)$ \\
\hline GLD6 & 2,204 & 0,09 & 0,11 & 1,22 & 1,18 & 1,14 & 0,96 & 1,96 & $-1,97$ & $-1,86$ & 5,46 & \\
\hline GLD7 & 4,597 & 0,22 & 0,27 & 1,22 & 0,82 & 0,79 & 0,96 & 1,46 & $-1,30$ & $-1,05$ & 19,34 & \\
\hline GLD8 & 5,722 & 0,04 & 0,04 & 1,18 & 1,54 & 1,54 & 1,00 & 2,30 & $-2,17$ & $-2,14$ & 1,19 & \\
\hline GLE1 & 1,161 & 1,52 & 1,64 & 1,08 & 0,21 & 0,23 & 1,11 & 1,51 & 2,73 & 2,71 & $-0,63$ & $(1)$ \\
\hline GLE2 & 2,257 & 0,86 & 1,09 & 1,38 & 0,32 & 0,30 & 0,93 & 0,92 & 1,66 & 2,08 & 25,44 & $(1\} \mathrm{e}(2)$ \\
\hline GLE3 & 4,637 & 0,45 & 0,53 & 1,17 & 0,65 & 0,59 & 0,90 & 2,10 & 0,10 & 0,48 & 380,76 & $(2)$ \\
\hline GLE4 & 3,315 & 0,61 & 0,67 & 1,10 & 0,87 & 0,80 & 0,92 & 3,11 & 0,41 & 0,67 & 61,91 & $(2)$ \\
\hline GLE5 & 4,543 & 0,23 & 0,27 & 1,20 & 0,96 & 0,91 & 0,95 & 3,37 & $-0,83$ & $-0,60$ & 27,48 & $(2)$ \\
\hline GLE6 & 3,843 & 0,12 & 0,12 & 1,06 & 1,15 & 1,16 & 1,01 & 4,23 & $-1,17$ & $-1,15$ & 1,91 & \\
\hline GLE7 & 2,888 & 0,11 & 0,13 & 1,18 & 1,18 & 1,14 & 0,96 & 4,10 & $-1,28$ & $-1,17$ & 7,99 & \\
\hline GLE8 & 1,021 & 0,93 & 1,18 & 1,28 & 0,30 & 0,23 & 0,78 & 1,23 & 1,90 & 2,37 & 24,78 & $(1\} \mathrm{e}(2)$ \\
\hline GLE9 & 1,349 & 0,29 & 0,32 & 1,10 & 0,81 & 0,81 & 1,01 & 1,62 & $-0,92$ & $-0,81$ & 11,34 & \\
\hline GLE10 & 1,674 & 0,24 & 0,26 & 1,07 & 0,86 & 0,87 & 1,01 & 2,63 & $-0,89$ & $-0,84$ & 5,73 & \\
\hline GLE11 & 2,196 & 0,16 & 0,20 & 1,22 & 1,32 & 1,26 & 0,95 & 4,70 & $-0,94$ & $-0,78$ & 16,88 & \\
\hline GLE12 & 2,364 & 0,28 & 0,33 & 1,19 & 1,09 & 1,10 & 1,01 & 2,43 & $-1,05$ & $-0,88$ & 15,98 & \\
\hline GLE13 & 1,641 & 0,31 & 0,35 & 1,12 & 0,81 & 0,78 & 0,96 & 1,45 & $-0,90$ & $-0,71$ & 20,52 & \\
\hline GLE14 & 2,658 & 0,04 & 0,07 & 1,67 & 1,61 & 1,56 & 0,97 & 2,51 & $-2,10$ & $-2,00$ & 4,74 & \\
\hline GLE15 & 2,802 & 0,01 & 0,01 & 1,16 & 2,35 & 2,37 & 1,01 & 3,31 & $-1,98$ & $-1,98$ & 0,20 & \\
\hline
\end{tabular}

Fonte: Seminário Guarapiranga 2006 baseado no "Diagnóstico Socioambiental Participativo da Guarapiranga", ISA/FEHIDRO

(1) mais problemáticas do ponto de vista ambiental e de produção de água em quantidade e qualidade;

(2) altas variações, superiores a $20 \%$ 


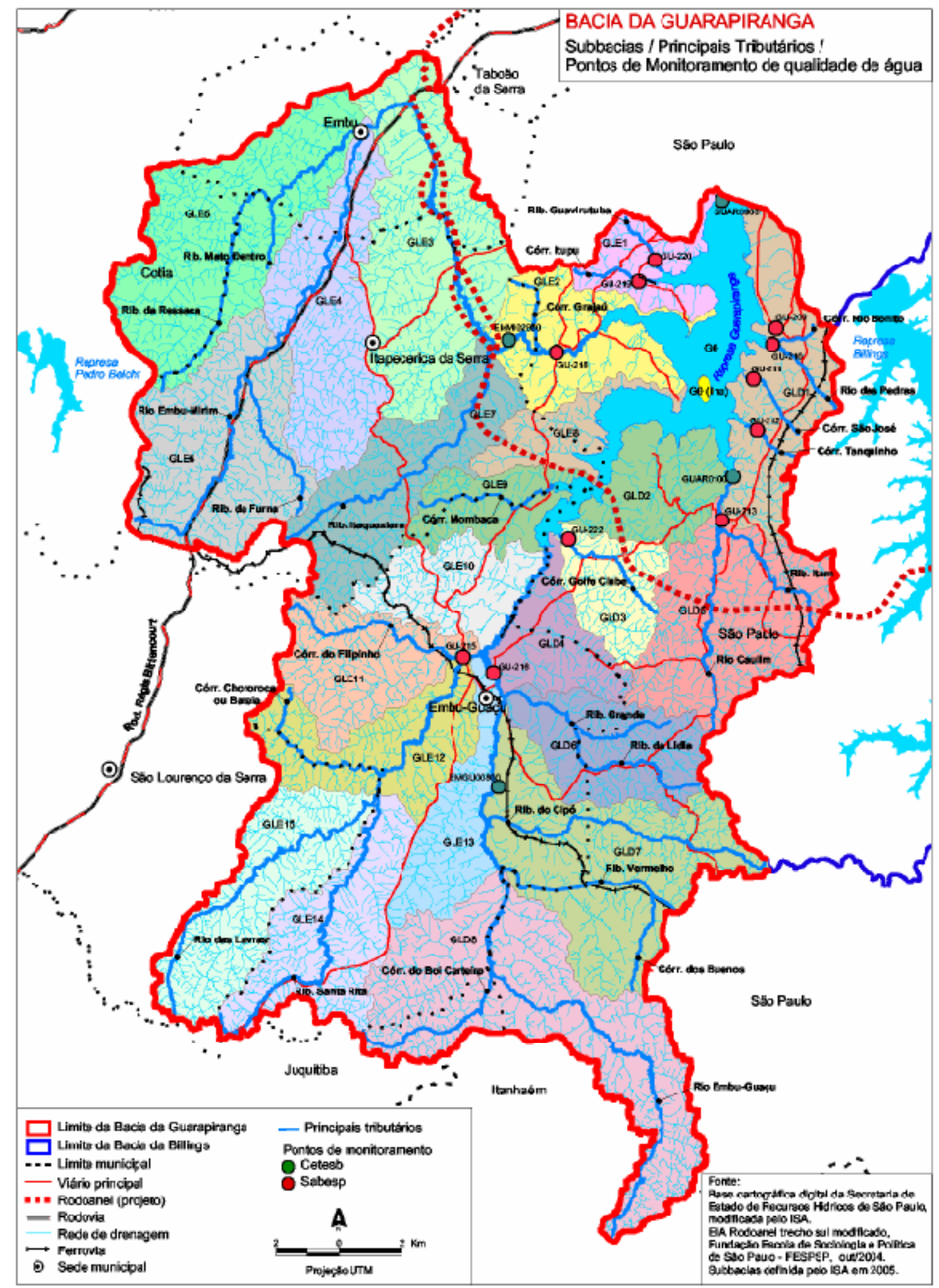


6.5.2. Análise Integrada entre evolução do uso do solo e da qualidade da água, e as intervenções do Programa de Saneamento Ambiental da Bacia Guarapiranga.

Com o intuito de verificar variações significativas na qualidade da água nos diferentes pontos de tributários e do reservatório monitorados pela SABESP e pela CETESB, foram analisadas as concentrações dos parâmetros em função do tempo no período de 1988 a 2004. As tendências de aumento ou diminuição das concentrações desses parâmetros foram analisadas em conjunto com o ICPH verificando a relação entre a variação desse índice e a qualidade da água.

As análises de evolução dos parâmetros de qualidade da água dizem respeito a cada ponto de monitoramento e as informações resultantes foram analisadas em conjunto com as intervenções do Programa de Saneamento Ambiental da Bacia da Guarapiranga.

Tabela 33 - IPCH entre 1989 - 2003

\begin{tabular}{|c|c|c|c|c|c|c|c|}
\hline \multirow[t]{2}{*}{ Sub-bacias } & \multirow[t]{2}{*}{$\begin{array}{c}\mathrm{IPCH}- \\
\text { variação } \\
(89-03) \\
\end{array}$} & \multicolumn{4}{|c|}{$\begin{array}{l}\text { Pontos de Monitoramento de água e evolução } \\
\text { da qualidade da água }\end{array}$} & \multirow[t]{2}{*}{$\begin{array}{l}\text { Tendência } \\
\text { Geral }\end{array}$} & \multirow[t]{2}{*}{$\begin{array}{l}\text { Intervenções } \\
\text { do Programa } \\
\text { Guarapiranga }\end{array}$} \\
\hline & & Sabesp & & Cetesb & & & \\
\hline \multirow[t]{2}{*}{$\begin{array}{l}\text { GO } \\
\text { (reservató- } \\
\text { rio) }\end{array}$} & & & & $\begin{array}{l}\text { GUA0900 } \\
\text { (captação) }\end{array}$ & $\begin{array}{l}\text { Diminuição } \\
\text { do IQA, } \\
\text { aumento de } \\
\text { DBO e } \\
\text { amônia }\end{array}$ & piora & \\
\hline & & & & GUA-0100 & & $\begin{array}{l}\text { Sem } \\
\text { tendência }\end{array}$ & \\
\hline \multirow[t]{4}{*}{ GLD1 } & $-0,88$ & $\begin{array}{l}\text { GU- } \\
209\end{array}$ & & & & $\begin{array}{l}\text { Sem } \\
\text { tendência }\end{array}$ & 3 EEEs \\
\hline & & $\begin{array}{l}\text { GU- } \\
210\end{array}$ & $\begin{array}{l}\text { Diminuição } \\
\mathrm{P} \text { total }\end{array}$ & & & Melhora & \\
\hline & & $\begin{array}{l}\text { GU- } \\
211\end{array}$ & & & & $\begin{array}{l}\text { Sem } \\
\text { tendência }\end{array}$ & \\
\hline & & $\begin{array}{l}\text { GU- } \\
212\end{array}$ & & & & $\begin{array}{l}\text { Sem } \\
\text { tendência }\end{array}$ & \\
\hline GLD3 & 7,04 & $\begin{array}{l}\text { GU- } \\
222\end{array}$ & $\begin{array}{l}\text { Diminuição } \\
\mathrm{P} \text { total }\end{array}$ & & & Melhora & \\
\hline GLD5 & 91,92 & GU-213 & $\begin{array}{l}\text { Aumento } \\
\text { Ntotal, DQO }\end{array}$ & & & Piora & $\begin{array}{l}5 \text { EEEs, } 2 \text { lotes } \\
(4 \text { e } 8) \text { de } \\
\text { ampliação da } \\
\text { rede de esgoto }\end{array}$ \\
\hline GLD6 & 5,46 & GU-216 & Diminuição & $\begin{array}{l}\text { EMGU- } \\
0800\end{array}$ & & Sem & 6 EEEs, lote 7, \\
\hline GLD7 & 19,34 & & Ptotal, & & & tendência & $\begin{array}{l}\text { Pq.Várzea do } \\
\text { Rio }\end{array}$ \\
\hline
\end{tabular}




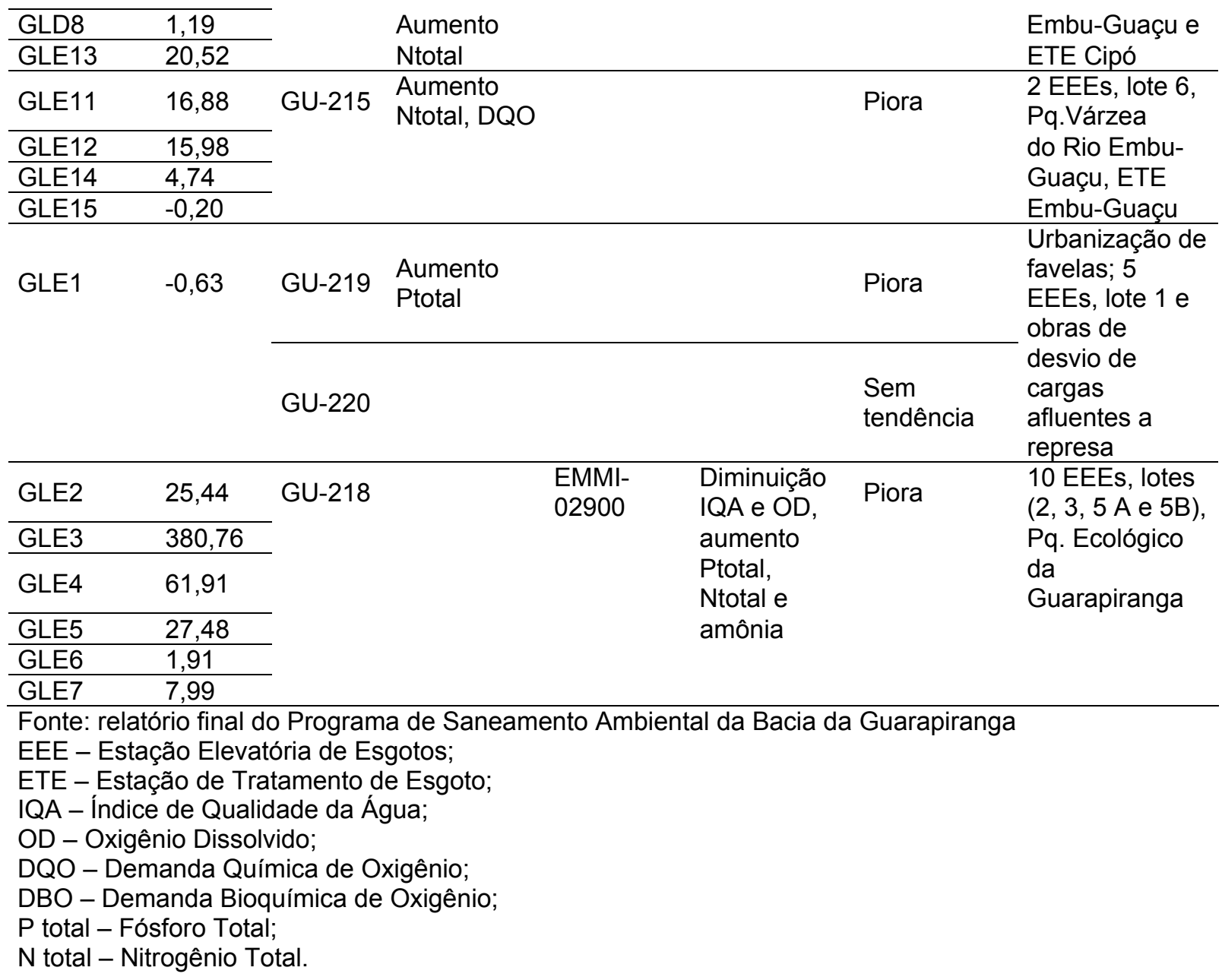

No período analisado na maioria dos pontos utilizados para o monitoramento, inclusive na captação próxima à barragem, a qualidade da água piorou. A análise entre evolução do uso do solo, qualidade da água e intervenções do Programa Guarapiranga demonstra que as obras de saneamento realizadas não foram suficientes para diminuir o aporte de cargas poluidoras e que a maioria dos pontos de monitoramento da qualidade da água apresenta tendência de piora.

O diagnóstico dos resultados verificou um elevado aporte de esgoto doméstico, característica da intensa urbanização, que contribui para elevadas concentrações do parâmetro Fósforo Total, fator limitante na floração de algas e conseqüente presença de Clorofila A. 
Portanto, a análise do indicador ambiental Índice de Estado Trófico (IET), que é definido pela presença destes dois parâmetros, através da avaliação e compreensão dos impactos decorrentes associados ao ciclo de vida do processo produtivo de água para o abastecimento urbano, fornece subsídios para identificar as distorções na valoração econômica dos danos ambientais provocados sobre os recursos hídricos, resultantes do processo de urbanização não planejado da Bacia Hidrográfica do Guarapiranga na Região Metropolitana de São Paulo, e podem indicar novas estratégias para o desenvolvimento sócio econômico e ambiental, de modo sustentável na região.

A ocorrência de uma degradação que resulte em danos ao meio ambiente e pode causar reflexos ao patrimônio da entidade responsável pelo fornecimento do recurso, requer uma ação gerencial que vise minimizar o prejuízo.

Torna-se necessário identificar o impacto para definir ações que possam trazer benefícios para a sociedade e para a empresa, materializadas através dos resultados da confrontação de custos de degradação com a economia de custos que deixam de ocorrer no processo produtivo.

Focando a escolha dos parâmetros representativos para um determinado cenário, aplica-se a metodologia de valoração econômica adequada, conforme apresentado no próximo capítulo. 


\section{METODOLOGIA}

Como visto, são inúmeras as metodologias para valoração econômica de recursos ambientais.

A análise de valoração feita através da aplicação do Método de Produtividade Marginal - MPM representa uma função dose-resposta que relaciona o nível de provisão do recurso ambiental ao nível de produção respectivo.

Para isso, está relacionada a quantidade e/ou a qualidade no uso do recurso ambiental de fluxo "água" diretamente à produção da água para abastecimento público, como um produto com preço definido no mercado, resultante de medidas de proteção e recuperação dos danos causados ao recurso.

As análises feitas consideram as causas dos impactos resultantes, para as condições de uso e ocupação, possibilitando valorar cada incremento das variáveis através da metodologia dose-resposta onde, esta função irá mensurar o impacto no sistema produtivo, dada uma variação marginal na provisão do bem ou serviço ambiental, e a partir desta variação, estimar o valor econômico de uso do recurso ambiental.

A construção da função dose-resposta envolve duas etapas básicas:

1. Elaboração de uma função física dos danos, relacionando a dose de poluição ou degradação à resposta do ativo ambiental poluído ou degradado na produção.

2. Formulação de um modelo econômico que mensure o impacto financeiro destas alterações no processo produtivo.

A função exige a inclusão de múltiplas variáveis, e um estudo de campo bem detalhado para conhecimento de todos os agentes que participam do processo. 
Para precisar as relações causa/efeito, impacto/resposta ambiental, será utilizada a Matriz PEIR, na compreensão dos problemas e fenômenos urbano-ambientais ocasionados pelo uso e ocupação desordenada, por meio da identificação e caracterização de indicadores ambientais e suas relações com os diferentes recursos ambientais envolvidos.

Como o método trata a qualidade da água para abastecimento público como um fator de produção, mudanças na qualidade da água levam a mudanças na produtividade e custos de produção, os quais levam, por sua vez, a mudanças nos preços de tratamento e níveis de produção, que podem ser observados e mensurados.

Para o estudo de valoração do impacto ambiental sobre o recurso hídrico, decorrente da ocupação desordenada, será necessária uma análise de indicadores de qualidade da água.

Esses indicadores são determinados através das medições de controle dos níveis normatizados para cada uma das variáveis especificadas.

A ocupação desordenada gera uma deficiência no sistema de saneamento básico da bacia onde, a maior causa de degradação do recurso hídrico é o esgoto doméstico, rico em nutrientes como o fósforo que é a variável limitante do processo de eutrofização.

Devido os inúmeros parâmetros que podem ser utilizados para caracterizar a qualidade da água e, também, diante do levantamento dos dados obtidos em pesquisa, focando o estudo para um indicador que será adequado à situação, a análise adota o Índice de Estado Trófico das Águas - IET, cujos principais parâmetros de qualidade da água envolvidos são Fósforo e Clorofila $A$. 
Nesta escolha, a presença desses parâmetros caracteriza um estado de impacto proveniente do excesso de poluição doméstica gerada, rica em nutrientes, e lançada no corpo hídrico, principal decorrência do uso e a ocupação desordenada.

Nesse índice, os resultados correspondentes ao fósforo, IET(P), devem ser entendidos como uma medida do potencial de eutrofização, já que este nutriente atua como o agente causador do processo.

A avaliação correspondente à clorofila A, IET (CL), por sua vez, deve ser considerada como uma medida da resposta do corpo hídrico ao agente causador, indicando de forma adequada o nível de crescimento de algas que tem lugar em suas águas.

Deve-se ter em conta que num corpo hídrico, em que o processo de eutrofização encontra-se plenamente estabelecido, o estado trófico determinado pelo índice da clorofila $A$, certamente coincidirá com o estado trófico determinado pelo índice do fósforo.

Assim, o índice médio engloba, de forma satisfatória, a causa e o efeito do processo.

A metodologia de valoração indica que medidas preventivas e corretivas geram custos que devem ser avaliados e incorporados através de instrumentos de cobrança.

Porém, os dados financeiros (monetários) correspondentes aos custos gerados por cada variável de definição do indicador, necessários para o tratamento da água, neste estudo não estão quantificados, as equações estão apresentadas literalmente, devido à indisponibilidade de informações econômica - financeiras. 


\subsection{Elaboração da função física dos impactos, relacionando a dose de poluição à resposta do recurso hídrico degradado na produção para abastecimento público.}

\subsubsection{Identificação dos Impactos em função da progressiva ocupação da bacia.}

A Guarapiranga encontra-se seriamente ameaçada pela ocupação urbana desordenada e poluição de suas águas. Os resultados do Diagnóstico Socioambiental Participativo da Bacia Hidrográfica do Guarapiranga, realizado pelo Instituto Sócio Ambiental (ISA) em 1996, mostraram um quadro preocupante. De 1989 a 1996, a Guarapiranga perdeu $15 \%$ de sua cobertura vegetal e teve um crescimento urbano de $50 \%$.

Conforme os estudos desenvolvidos para o PDPA e baseados na Carta Geotécnica do Estado de São Paulo, a Bacia do Guarapiranga apresenta de forma geral, como resposta às modificações do meio físico, resultantes de atividades antrópicas (agropastoris, assentamentos, implantação de infra-estrutura, sistema viário, etc.), alta suscetibilidade a erosões nos solos superficiais, induzidas por movimento de terra; média suscetibilidade a escorregamentos $e$, nas áreas correspondentes às planícies aluvionais, tem-se alta suscetibilidade a inundações, recalques, assoreamento e solapamento das margens dos rios.

Os locais mais desfavoráveis - encostas com declividades elevadas, cabeceiras de drenagem e margens de córregos - foram ocupados por favelas, constituindo-se nos principais focos de risco geotécnico na região, agravando-se conforme são maiores a área de contribuição do curso d'água e o gradiente de declividade da drenagem.

Nessas favelas encontram-se edificações implantadas em cortes realizados nas encostas, sem nenhum controle geotécnico, ou nas margens dos cursos d'água sobre palafitas, onde ainda identificam-se, pela própria exposição às freqüentes inundações, moradias de madeira, plástico, etc. de modo geral, tanto nas encostas como nos fundos de vale, seja pela precariedade construtiva, seja pela inadequada implantação e 
ausência de infra-estrutura de saneamento básico, as moradias são extremamente insalubre, apresentando problema de infiltração, rachadura, instabilidade estrutural.

De um modo geral, antes da urbanização, não existem vias que permitam o acesso de automóveis, ambulâncias, coleta de lixo, etc. Assim, o lançamento de esgotos e acúmulo de resíduos sólidos, ao longo das vielas e nos cursos d'água, ocasiona situações de extrema insalubridade e ameaça à saúde da população moradora, além dos graves problemas de risco geotécnico, deslizamentos e inundações, a que estão sujeitos.

A ocupação desordenada e irregular, as deficiências nos projetos de parcelamento e a ocupação de áreas pouco favoráveis, como encostas e fundos de vale, assim como, as várias interferências de uma área sobre a outra (áreas públicas $\mathrm{x}$ áreas particulares), promovem um quadro de extrema complexidade, potencializada com obras de urbanização e adequação de infra-estrutura em loteamentos. Este cenário encontra-se mais fortemente do lado esquerdo da bacia do Guarapiranga, assim como na porção sul da margem direita, a existência de situações fundiárias com várias sobreposições:

- loteamentos aprovados e regularizados, com infra-estrutura básica;

- loteamentos não aprovados, mas consolidados com infra-estrutura básica;

- loteamentos não aprovados, mas consolidados e carentes de infraestrutura básica;

A área de influência da represa apresenta uma ocupação urbana constituída basicamente pelo uso habitacional e terciário de apoio. Tanto os loteamentos regulares como os clandestinos, visando atingir o aproveitamento máximo para os lotes com valor de mercado, reservam para os espaços públicos os setores mais desfavoráveis, como encostas ou fundos de vale. Estas áreas pela dificuldade de uso se transformam em depósitos de lixo e, são ocupadas por favelas, em um crescente processo de degradação social e ambiental. 
É importante destacar que o perfil econômico da região caracteriza-a como uma das mais pobres de São Paulo e, que isto está diretamente relacionado aos principais fatores de poluição do reservatório, que o diferencia dos ecossistemas tradicionais nos quais as causas da degradação são detectáveis, mas aqui a predominância é de milhares de fontes dispersas de poluição, as cargas difusas.

A disposição do lixo em áreas de mananciais vem se constituindo em prática comum. Em uma área de proteção de mananciais, além dos aspectos negativos de ordem estética e paisagística, a disposição do lixo traz uma série de inconvenientes relacionados à poluição e contaminação de águas superficiais e subterrâneas.

Figura 9 - Ciclo do modelo de abordagem PEIR

\begin{tabular}{|c|c|}
\hline $\begin{array}{l}\text { PRESSÃO - atividades humanas e sua dinâmica } \\
\text { que são as causas dos problemas ambientais } \\
\text { - Crescimento e densidade populacional } \\
\text { - Expansão da área urbanizada } \\
\text { - Redução da cobertura vegetal } \\
\text { - Consumo de água } \\
\text { - Destinação de águas residuárias e pluviais } \\
\text { - Atividades poluidoras - lançamento de } \\
\text { esgoto doméstico e industrial. }\end{array}$ & $\begin{array}{l}\text { ESTADO - condições do ambiente que são } \\
\text { resultados dessas atividades } \\
\text { - Qualidade das águas superficiais } \\
\text { - Qualidade da água de abastecimento } \\
\text { - Escassez de água } \\
\text { - Aporte de sedimentos } \\
\text { - Diminuição da capacidade de retenção } \\
\text { do solo } \\
\text { - Aceleração do processo erosivo }\end{array}$ \\
\hline $\begin{array}{l}\text { RESPOSTA - ações para melhorar o estado do } \\
\text { meio ambiente, bem como prevenir, mitigar e } \\
\text { corrigir os impactos ambientais negativos } \\
\text { decorrentes atividades } \\
\text { - Controle de Cargas Poluidoras } \\
\text { - Investimento em infra-estrutura de Água e } \\
\text { Esgoto } \\
\text { - Investimento em Gestão de Resíduos Sólidos } \\
\text { - Ampliação da Cobertura Vegetal } \\
\text { - Recuperação de Áreas de Risco } \\
\text { - Plano Diretor Municipal } \\
\text { - Legislação de Proteção a Mananciais } \\
\text { - Tributação Ambiental } \\
\text { - Educação Ambiental } \\
\text { - Sanções por Infrações as Normas Ambientais }\end{array}$ & $\begin{array}{l}\text { IMPACTO - efeito adverso à qualidade de } \\
\text { vida, ao ecossistema e a sócio-economia } \\
\text { local } \\
\text { - Custos de captação, condução e } \\
\text { tratamento de água }\end{array}$ \\
\hline
\end{tabular}


Como visto, são inúmeras as causas e conseqüentes impactos que podem ser estudados e valorados.

Considerando apenas o aspecto de qualidade da água, existe um vasto número de parâmetros que podem ser medidos.

Analisando o aspecto de uso e ocupação do solo, os dados da tabela 19 - Expansão Urbana na Bacia da Guarapiranga entre 1989 e 2003, mostram que a ocupação urbana de alta densidade teve um incremento de 9,3\%, a de média densidade de $30,8 \%$ e a de ocupação dispersa $24,9 \%$ o que representou uma média de $19,2 \%$ no incremento de expansão urbana na bacia.

Essa expansão se confirma pelo crescimento populacional indicado na tabela 21 Crescimento da População na Bacia, para o período entre 1991 e 2000, em 37,8\%.

Na análise da Carga Orgânica Potencial, demonstrada na tabela 22, pode-se verificar que para o período entre 2000 e 2006, a população urbana de São Paulo passou de 9.785.640 para 9.975.563 habitantes e a carga orgânica potencial incidente no corpo hídrico receptor passou de 528425 para $538686 \mathrm{~kg}$ DBO/dia, conclui-se que um acréscimo populacional de 189.923 habitantes pode ter acarretado um acréscimo de $10261 \mathrm{~kg} \mathrm{DBO} /$ dia, logo 0,054 Kg DBO/dia por habitante.

Portanto, o uso desordenado do solo mostra ser um indicador de degradação da qualidade da água devido ao acréscimo de carga orgânica poluidora de origem doméstica.

Para aplicar a metodologia da função dose-resposta, a análise foi focada no índice de estado trófico - IET, que utiliza os parâmetros de fósforo total e clorofila $A$ e são 
indicadores que demonstram a presença de poluição proveniente de esgoto doméstico, característica da ocupação desordenada.

No estudo, o aumento da presença da clorofila A na água para abastecimento causada pelo aumento do fósforo total, torna necessário um acréscimo na aplicação de algicidas, como o cobre, no processo de tratamento para a redução da clorofila A.

\subsubsection{A Ocupação da Bacia e seu Impacto sobre o Recurso Hídrico para Abastecimento}

O Reservatório Guarapiranga é um manancial cuja condição de qualidade mais preocupante é em relação ao seu nível trófico. O Programa Guarapiranga já vem atuando no sentido de remediar tal situação, mas ela continua evoluindo de forma desfavorável, de acordo com Porto (2003), devido ao crescimento populacional nas áreas de proteção, a restrição à aplicação de sulfato de cobre no lago e ao acréscimo de carga adicional de fósforo da reversão do braço do Taquacetuba, onde a vazão média regularizada é de $1,7 \mathrm{~m} 3 / \mathrm{s}$, possuindo uma parcela proveniente do corpo central da Billings que possui grande diversidade do gênero de algas e espécies de zooplancton que não existem na Guarapiranga.

A captação de água bruta da Sabesp é realizada em território do município, próxima às sub-bacias que concentram grandes densidades demográficas, e se constituem nos cursos d'água que mais contribuem para o carreamento de cargas de fósforo e nitrogênio para o reservatório.

A deterioração da qualidade da água do reservatório vem ocorrendo desde a década de 1980, quando foram registrados incrementos de floração de algas e crescente processo de eutrofização. A situação de deterioração progressiva perdura até hoje, em função do crescente aumento do despejo de esgotos e da poluição difusa que resulta em grandes aportes de nutrientes, como fósforo e nitrogênio, e coliformes totais. 
Em 1995, estimava-se a carga de fósforo produzida na bacia em $245 \mathrm{~kg} / \mathrm{dia}$, no período seco, $88 \%$ originários de esgoto doméstico. As metas para recuperação do lago são, para o curto prazo, as reduções para $194 \mathrm{~kg} /$ dia da carga de fósforo e para 2015, 147 $\mathrm{kg} / \mathrm{dia}$.

A maior parte da poluição transportada para o reservatório, cerca de $80 \%$, tem origem nos esgotos domésticos. O sistema de esgotamento sanitário nas margens esquerda e direita da bacia atende a apenas $45 \%$ da população. Somem-se a isso as deficiências nos sistemas de drenagem, cuja decorrência é a erosão e o carreamento de sedimentos e resíduos sólidos que causam o assoreamento de córregos contribuintes e conseqüentemente da própria represa.

Como ferramenta de visualização para e elaboração da função física dos impactos decorrentes da ocupação desordenada, focados no indicador "Índice de Eutrofização" que analisa os parâmetros de Fósforo Total e Clorofila A, abordados nesta análise, que relaciona a variação da dose de poluição à resposta do recurso hídrico degradado, com a alteração do custo na produção de água para abastecimento público, foi utilizada a Matriz PEIR, conforme representada abaixo.

Figura 10 - Ciclo do modelo de abordagem PEIR para qualidade da água analisada pelo Índice de Eutrofização

\begin{tabular}{|l|l|l|}
\hline $\begin{array}{l}\text { PRESSÃO - } \\
\text { - Atividades poluidoras - lançamento de } \\
\text { esgoto doméstico e industrial }\end{array}$ & $\begin{array}{l}\text { ESTADO - } \\
\text { - Qualidade das águas superficiais - } \\
\text { presença de fósforo total }\end{array}$ \\
- Qualidade das águas superficiais - \\
presença de clorofila A
\end{tabular}


Ou seja, com a intensificação da ocupação não planejada, associada à falta de infraestrutura urbana e de saneamento, gera um acréscimo no lançamento de cargas poluidoras, o que caracteriza uma pressão sobre o estado de uso do manancial que, com o aumento da presença de Fósforo Total e conseqüente presença da clorofila $A$ produzida pela proliferação das algas, causa variação do estado da qualidade da água na captação, onde o impacto da variação do custo de tratamento no sistema produtivo da água para abastecimento tem como resposta a necessidade do acréscimo na aplicação insumos como algicidas (cobre).

Isto, também, pode ser evidenciado em outros parâmetros de qualidade como a turbidez que resulta na necessidade de acréscimo de produtos químicos na entrada da Estação de Tratamento de Água.

\subsection{Formulação do Modelo Econômico que mensure o impacto financeiro na produção de Água para Abastecimento Público.}

O método de produtividade marginal atribui um valor ao uso da água bruta, na captação, relacionando sua qualidade, avaliada no ponto de monitoramento, diretamente à produção de água para abastecimento público. Para o processo produtivo está representada uma função dose-resposta que relaciona o nível de provisão da água bruta ao nível de produção da água tratada para abastecimento público (produto no mercado).

Esta função irá mensurar o impacto no sistema produtivo da água para abastecimento público, dada uma variação marginal de acréscimos dos elementos necessários ao tratamento, para que o produto final atinja a qualidade, e a partir desta variação, estimar o valor econômico de uso do recurso ambiental água.

No estudo, o aumento da presença da clorofila A na água para abastecimento, causada pelo aumento do fósforo total, torna necessário um acréscimo na aplicação de algicidas, como o cobre, no processo de tratamento para a redução da clorofila a. 
Caracterizando, o recurso ambiental E como o insumo água bruta ou fator na produção do produto $\mathbf{Z i}$, como água para abastecimento, estima-se a variação de produto de $\mathrm{Zi}$ decorrente da variação da quantidade de algicidas (cobre) que são necessários aplicar sobre o recurso ambiental $\mathbf{E}$ na produção de $\mathbf{Z i}$ (em uma dada condição de tratamento).

A função de produção de $Z$, tal o nível de produção de $Z i$ é dada pela seguinte expressão:

$$
Z=F(X, E)
$$

Onde:

$\mathbf{X}$ é um conjunto de insumos utilizados no tratamento - Cobre.

E representa água bruta na captação (condição inicial sob padrão de potabilidade estabelecido em legislação) que é utilizada gratuitamente, ou seja, seu preço de mercado $P_{E}$ é zero.

$\mathbf{Z}$ água para abastecimento

Para cada uma das condições do estado da água na captação para tratamento será necessária a aplicação de um determinado valor das variáveis necessárias para o seu tratamento.

Ou seja, o valor da água para abastecimento é função $(\mathbf{F})$ da variação do gasto necessário com aplicação dos elementos utilizados no tratamento $(X)$ em função a uma determinada condição no estado da água bruta $(E)$.

Como o método de produtividade marginal assume que o preço da água para abastecimento $\left(P_{Z}\right)$ é conhecido, o valor econômico da água na captação $E\left(V E_{E}\right)$ seria:

$$
\mathrm{VE}_{\mathrm{E}}=\mathrm{Pz} \Delta \mathrm{F} / \Delta \mathrm{E}
$$


Conhecendo a correlação de $E$ em F ou as funções dose-resposta (DR) onde:

$$
E=D R(x 1, x 2, \ldots, Q E)
$$

Onde, xi são as variáveis que, junto com o nível de estoque (quantidade ou qualidade) $Q$ do recurso água na captação, afetam o nível de $E$.

Logo,

$$
\Delta E=\Delta \mathrm{DR} / \Delta \mathbf{Q E}
$$

Determinada a DR, é possível, então, estimar a variação do dano em termos de variação no custo da produção de água para abastecimento público.

Operacionalmente gerencia-se quantidade e qualidade no aspecto físico e, no econômico, os custos dos recursos consumidos e as receitas geradas pelo produto. 


\title{
8. CONCLUSÕES
}

\begin{abstract}
4 Poderia ser aplicado qualquer um dos Métodos de Valoração Econômica apresentados. Cada método de valoração ambiental tem suas especificidades, limitações e situações mais adequadas para sua aplicação, que devem ser analisadas a priori.
\end{abstract}

No caso específico da aplicação de uma função dose-resposta entre a concentração dos poluentes e os efeitos sobre a qualidade da água, existem algumas dificuldades:

- a variedade de poluentes presentes na água e a interação entre eles dificultam a associação exata dos tipos de poluentes e seus respectivos efeitos; o ideal é isolar e identificar o efeito real de cada um dos poluentes;

- neste estudo está citado o fósforo como causador da presença da clorofila A proveniente da existência de algas, poderia ser analisado o parâmetro da turbidez.

- essas variáveis sofrem alterações relacionadas ao clima, como a temperatura, a umidade relativa e a pluviosidade também devem ser consideradas como eventuais dificuldades;

- as variáveis relacionadas à topografia, ao saneamento básico, às especificidades do local e ao estilo de vida da população afetada pela poluição, devem ser consideradas quando se estabelece a função doseresposta.

As dificuldades relacionadas não são exaustivas, apesar disto não invalidam o esforço de se valorar monetariamente as externalidades ambientais, fazendo-se uso de funções do tipo DR. 
A escolha destes dois parâmetros, neste estudo, deveu-se ao fato de estarem diretamente relacionados, ou seja, a variação do nível de clorofila $A$ está diretamente relacionada ao nível de variação do fósforo total.

$\mathrm{O}$ valor econômico do recurso ambiental $\left(V_{E}\right)$ representa apenas valores de usos diretos ou indiretos relativos a bens e serviços ambientais. Neste caso, para o tratamento da qualidade da água que sofre variação da presença da clorofila $A$, é necessária a aplicação de gradiente de algicidas (Cobre) utilizados na produção da água tratada nos padrões de potabilidade.

A metodologia não pode ser comprovada numericamente, devido à indisponibilidade das informações de valores monetários para os custos de aplicação de insumos necessários ao tratamento da água pela empresa responsável. Porém, este estudo está disponibilizado para qualquer análise de interesse. A possibilidade seria analisar o parâmetro da turbidez na entrada da estação de tratamento de água, a partir do custo do tratamento com a aplicação dos produtos químicos necessários.

O estabelecimento das funções dose-resposta (DR) pode representar uma tarefa árdua e pouco precisa na medida em que as relações causais em ecologia são ainda pouco conhecidas e de estimativa bastante complexa. As relações ecológicas requerem estudos de campo muitas vezes sofisticados, nem sempre adaptáveis de uma região a outra, e a consideração de um grande número de variáveis. Além do que, as variações nas condições de dispersão dos poluentes nem sempre são possíveis de serem avaliadas.

Outra dificuldade é a identificação da população afetada em países como o Brasil, em geral, é feita com dados secundários, utilizando os anuários estatísticos, que nem sempre contém os dados exatos da população existente no local a ser impactado. 
Porém, mais do que requintes e precisões de ordem teórica, o meio ambiente demanda decisões que possam preservá-lo de modo racional, e muitas vezes, estas estimativas constituem nas únicas disponíveis e passíveis de serem utilizadas para motivar decisões que envolvam a variável qualidade ambiental.

A valoração econômica é um importante critério no processo de tomada de decisões na definição de políticas ambientais e de desenvolvimento sustentável, além de importante fator de conscientização da população à medida que na gestão ambiental a degradação pode causar prejuízo, não somente para a empresa responsável pela recuperação, como para as gerações presentes e futuras devido à exaustão (com inviabilização técnica e econômica) do recurso que é indispensável à sobrevivência humana.

Este trabalho não pôde cobrir questões relativas à gestão do meio ambiente onde a preservação da área deve ser, principalmente, em defesa dos interesses da população local. A participação da sociedade consegue realizar a conscientização social, política, econômica, ambiental.

Em trabalhos futuros sugere-se o aprofundamento do modelo no que representa a formação do banco de preços da degradação produzida; com a discussão dos problemas relativos à objetividade e precisão dos preços envolvidos.

Com isso, essa ferramenta pode ser importante para tomadores de decisões. 


\section{BIBLIOGRAFIA}

Amazonas, M. C. Economia do meio ambiente: uma análise da abordagem neoclássica a partir de marcos evolucionistas e institucionalistas. Dissertação (mestrado). Instituto de Economia, UNICAMP, Campinas, 1994. $223 \mathrm{f}$.

Borger, F. G. Valoração econômica do meio ambiente: aplicação da técnica avaliação contingente no caso da Bacia do Guarapiranga. Dissertação (mestrado). Programa de Pós-Graduação em Ciência Ambiental, USP, São Paulo, 1995. 126 f.

Brown, Lester. A Economia e a Terra. Eco-Economia. Copyrights @ 2003, EPI - Earth Policy Institute / UMA-Universidade Livre da Mata Atlântica, in site: www.uma.org.br

Chaves, Flávio Teodoro. Planejamento Virtual: o Zoneamento EcológicoEconômico (ZEE) na Amazônia enquanto instrumento de política ambiental e territorial, 2000.

CNEC. JNS-Engenharia, Consultoria e Gerenciamento. Plano de Desenvolvimento e Proteção Ambiental da Bacia do Guarapiranga - PDPA. Diagnóstico Ambiental. Secretária de Recursos Hídricos, Saneamento e Obras - São Paulo, 1997.

Del Prette, Marcos Estevan. Apropriação de Recursos Hídricos e Conflitos Sociais: A Gestão das Áreas de Proteção aos Mananciais da Região Metropolitana de São Paulo. São Paulo, 2000. 190p. Tese de Doutorado, USP.

ELETROBRÁS. DEA. Metodologia de valoração das externalidades ambientais da geração hidrelétrica e termelétrica com vistas à sua incorporação no planejamento de longo prazo do setor elétrico. Centrais Elétricas Brasileiras S.A., DEA; coordenado por Mírian Regini Nutti. - Rio de Janeiro: Eletrobrás, 2000. ix, 210p.

Ensinas, Hedmilton. Impactos da política estadual de recursos hídricos e da urbanização nas áreas de proteção aos mananciais da Região Metropolitana de São Paulo. São Paulo, 2004. 230p. Dissertação de Mestrado em Saúde Ambiental, USP.

França, Elisabete (coordenadora). Guarapiranga - Recuperação Urbana e Ambiental no Município de São Paulo. - Edição Marcos Carrilho Arquitetos. São Paulo, 2000. 253p.

Instituto Sócio Ambiental (ISA, 2002). Avaliação e Identificação de áreas e ações prioritárias para conservação, recuperação e uso sustentável da Bacia Hidrográfica da Billings. Seminário Billings 2002, São Paulo. 
Instituto Socioambiental (ISA, 2006). Guarapiranga 2005: Como e porque São Paulo está perdendo este manancial. Resultado do Diagnóstico Socioambiental Participativo da Bacia Hidrográfica da Guarapiranga. São Paulo. . in site: www.isa.org.br

Instituto Socioambiental (ISA, 2006). Guarapiranga 2006: Análise Integrada da Evolução do Uso do Solo e Qualidade da Água na Bacia da Guarapiranga. Seminário Guarapiranga, 2006. São Paulo.

Iwai, Olga Kazuko. Mapeamento do uso do solo urbano do município de São Bernardo do Campo, através de imagens de satélites. São Paulo, 2003. 140p. Dissertação de Mestrado em Engenharia de Transportes, USP.

Kamogawa, Luiz Fernando Ohara. Crescimento econômico, uso dos recursos naturais e degradação ambiental: uma aplicação do modelo EKC no Brasil. Piracicaba, 2003. 142p. . Dissertação de Mestrado em Economia Aplicada, USP.

Maia, Alexandre Gori. Valoração de Recursos Ambientais. Dissertação de Mestrado Instituto de Economia, UNICAMP, Campinas, 2002. $183 \mathrm{f}$.

Ministério do Meio Ambiente - Secretária Executiva. Gestão Ambiental no Brasil: Um Compromisso com o Desenvolvimento Sustentável, Brasília, 2001.

Moreira, A.C.M.L. A Proteção aos Mananciais Paulistas. Apostila do Curso de Extensão "Controle Integrado de Fiscalização, Monitoramento e Vistoria em Áreas de Mananciais Metropolitanos: o Quadro da Guarapiranga. Unicamp, 1998.

Mori, Emilio. Proposta de Plano de Gestão e Zoneamento Ambiental para Área de Proteção Ambiental do Anhatomirim, Sc. Dissertação de Mestrado em Engenharia Ambiental, UFSC. Florianópolis, 1988. 187p.

MOTTA, R. S. Manual para valoração econômica de recursos ambientais. Ministério do Meio Ambiente, Recursos Hídricos e da Amazônica Legal, 1998. 218 p.

Muñoz, H.R. (Organizador) Secretaria de Recursos Hídricos. Interfaces da Gestão de Recursos Hídricos: desafios da lei de águas em 1997. 2ªedição Brasília, 2000.

Nogueira, J.M et al. Valoração Econômica do Meio Ambiente: ciência ou empiricismo? Cadernos de Ciência \& Tecnologia, Brasília, v.17, n.2, p.81-115, maio/ago. 2000.

Pearce, D. W. Economic values and the natural world. Massachusetts: The MIT Press, USA, 1993. 129 p.

Porto, M. Banco Mundial. Recursos Hídricos e Saneamento na Região Metropolitana de São Paulo: Um desafio do tamanho da cidade, Brasília, 2003, Série Água Brasil 3. $1^{\text {a }}$ edição $84 p$. 
Sales, M.M.L. Guarapiranga - Recuperação Urbana e Ambiental no Município de São Paulo. - A Ocupação da Represa e as Ações do Programa Guarapiranga.

Santos, N. M. Valoração de Impactos Ambientais em Áreas Protegidas - Estado da Arte. Coordenação de Ensino Superior e Pesquisa. Núcleo de Pesquisas em Petróleo, Energia \& Recursos Naturais. CEFET Campos, Macaé, 2005.

Secretária de Recursos Hídricos. Avaliação das Águas do Brasil, Brasília, 2002.

Secretária do Meio Ambiente - São Paulo. Gestão das águas: 6 anos de percurso, 1997.

Secretaria do Meio Ambiente. Qualidade das Águas Interiores no Estado de São Paulo. Série de Relatórios, Cetesb, 2000.

Secretaria do Meio Ambiente. Qualidade das Águas Interiores no Estado de São Paulo. Série de Relatórios, Cetesb, 2001.

Secretaria do Meio Ambiente. Qualidade das Águas Interiores no Estado de São Paulo. Série de Relatórios, Cetesb, 2002.

Secretaria do Meio Ambiente. Qualidade das Águas Interiores no Estado de São Paulo. Série de Relatórios, Cetesb, 2003.

Secretaria do Meio Ambiente. Qualidade das Águas Interiores no Estado de São Paulo. Série de Relatórios, Cetesb, 2004.

Secretaria do Meio Ambiente. Qualidade das Águas Interiores no Estado de São Paulo. Série de Relatórios, Cetesb, 2005.

Secretaria do Meio Ambiente. Qualidade das Águas Interiores no Estado de São Paulo. Série de Relatórios, Cetesb, 2006.

Secretária Municipal do Meio Ambiente - São Paulo. Atlas Ambiental do Município de São Paulo. Diagnóstico e Bases para a definição de políticas públicas para as áreas verdes no município de São Paulo, 2002.

SVMA, IPT. GEO Cidade de São Paulo: Panorama do Meio Ambiente Urbano. Prefeitura do Município de São Paulo. Secretaria Municipal do Verde e do Meio Ambiente; PNUMA - São Paulo, Brasília: 2004.

Tagnin, R.A. O Tratamento da expansão urbana na proteção aos mananciais. 0 caso da Região Metropolitana de São Paulo. São Paulo, 2000. 291p. Dissertação de Mestrado em Engenharia, USP. 
Venturi, Luis Antonio Bittar. Itapecerica da Serra - ocupação e uso do território. São Paulo, 2001. 173p. Tese de Doutorado, USP.

Young, C.E.F.et al. Sistemas de Contas Ambientais para o Brasil: Estimativas Preliminares. Texto para discussão IE/UFRJ nº 448, setembro 2000. 


\section{ANEXO I \\ SIGNIFICADO AMBIENTAL DOS PARÂMETROS (Cetesb, 2004)}

\section{VARIÁVEIS FÍSICAS}

Coloração - A cor de uma amostra de água está associada ao grau de redução de intensidade que a luz sofre ao atravessá-la devido à presença de sólidos dissolvidos, principalmente material em estado coloidal orgânico e inorgânico. Dentre os colóides orgânicos mencionam-se os ácidos húmico e fúlvico, substâncias naturais resultantes da decomposição parcial de compostos orgânicos presentes em folhas, dentre outros substratos. Também os esgotos sanitários se caracterizam por apresentarem predominantemente matéria em estado coloidal, além de diversos efluentes industriais contendo taninos (efluentes de curtumes, por exemplo), anilinas (efluentes de indústrias têxteis, indústrias de pigmentos, etc.), lignina e celulose (efluentes de indústrias de celulose e papel, da madeira, etc.). Há também compostos inorgânicos capazes de possuir as propriedades e provocar os efeitos de matéria em estado coloidal. Os principais são os óxidos de ferro e manganês, que são abundantes em diversos tipos de solo. Alguns outros metais presentes em efluentes industriais conferem-lhes cor mas, em geral, íons dissolvidos pouco ou quase nada interferem na passagem da luz. O problema maior de coloração na água, em geral, é o estético já que causa um efeito repulsivo aos consumidores.

Resíduo Total - Em saneamento, sólidos nas águas correspondem a toda matéria que permanece como resíduo, após evaporação, secagem ou calcinação da amostra a uma temperatura pré-estabelecida durante um tempo fixado. Para o recurso hídrico, os sólidos podem se sedimentar no leito dos rios destruindo organismos que fornecem alimentos, ou também danificar os leitos de desova de peixes; podem reter bactérias e resíduos orgânicos no fundo dos rios, promovendo decomposição anaeróbia. Altos teores de sais minerais, particularmente sulfato e cloreto, estão associados à tendência de corrosão em sistemas de distribuição, além de conferir sabor às águas. 
Temperatura - Variação de temperatura é parte do regime climático normal, e corpos de água naturais apresentam variações sazonais e diurnas, bem como estratificação vertical. A temperatura superficial é influenciada por fatores tais como latitude, altitude, estação do ano, período do dia, taxa de fluxo e profundidade. A elevação da temperatura em um corpo d'água geralmente é provocada por despejos industriais e usinas termoelétricas.

A temperatura desempenha um papel principal de controle no meio aquático, condicionando as influências de uma série de parâmetros físico-químicos. Em geral, à medida que a temperatura aumenta, de 0 a $30^{\circ} \mathrm{C}$, a viscosidade, tensão superficial, compressibilidade, calor específico, constante de ionização e calor latente de vaporização diminuem, enquanto a condutividade térmica e a pressão de vapor aumentam. Organismos aquáticos possuem limites de tolerância térmica superior e inferior, temperaturas ótimas para crescimento, temperatura preferida em gradientes térmicos e limitações de temperatura para migração, desova e incubação do ovo.

Turbidez - é o grau de atenuação de intensidade que um feixe de luz sofre ao atravessá-la devido à presença de sólidos em suspensão, tais como partículas inorgânicas (areia, silte, argila) e de detritos orgânicos, algas e bactérias, plâncton em geral, etc. A erosão das margens dos rios em estações chuvosas é um exemplo de fenômeno que resulta em aumento da turbidez das águas e que exigem manobras operacionais, como alterações nas dosagens de coagulantes e auxiliares, nas estações de tratamento de águas. A erosão pode decorrer do mau uso do solo em que se impede a fixação da vegetação. Este exemplo, mostra também o caráter sistêmico da poluição, ocorrendo inter-relações ou transferência de problemas de um ambiente (água, ar ou solo) para outro.

Alta turbidez reduz a fotossíntese de vegetação enraizada submersa e algas. Esse desenvolvimento reduzido de plantas pode, por sua vez, suprimir a produtividade de 
peixes, influenciando nas comunidades biológicas aquáticas. Além disso, afeta adversamente o uso doméstico, industrial e recreacional de uma água.

\section{VARIÁVEIS QUÍMICAS}

Alumínio - $\mathrm{Na}$ água, o alumínio é complexado e influenciado pelo $\mathrm{pH}$, temperatura e a presença de fluoretos, sulfatos, matéria orgânica e outros ligantes. A solubilidade é baixa em pH entre 5,5 e 6,0. O alumínio deve apresentar maiores concentrações em profundidade, onde o $\mathrm{pH}$ é menor e pode ocorrer anaerobiose. Se a estratificação, e conseqüente anaerobiose, não forem muito fortes, o teor de alumínio diminui no corpo de água como um todo, à medida que se distancia a estação das chuvas. $\mathrm{O}$ aumento da concentração de alumínio está associado com o período de chuvas e, portanto, com a alta turbidez. Outro aspecto chave da química do alumínio é sua dissolução no solo para neutralizar a entrada de ácidos com as chuvas ácidas. Nesta forma, ele é extremamente tóxico à vegetação e pode ser escoado para os corpos d'água. A principal via de exposição humana não ocupacional é pela ingestão de alimentos e água.

Bário - pode ocorrer naturalmente na água, na forma de carbonatos em algumas fontes minerais. Decorre principalmente das atividades industriais e da extração da bauxita. Não possui efeito cumulativo, sendo que a dose fatal para o homem é considerada de 550 a 600 mg. Provoca efeitos no coração, constrição dos vasos sangüíneos elevando a pressão arterial e efeitos sobre o sistema nervoso. O padrão de potabilidade é $1,0 \mathrm{mg} / \mathrm{l}$ (Portaria 1469).

Cádmio - apresenta-se nas águas naturais devido às descargas de efluentes industriais, principalmente as galvanoplastias, produção de pigmentos, soldas, equipamentos eletrônicos, lubrificantes e acessórios fotográficos. É também usado como inseticida. A queima de combustíveis fósseis consiste também numa fonte de cádmio para o ambiente. Apresenta efeito crônico, pois se concentra nos rins, no fígado, no pâncreas e na tireóide, e efeito agudo, sendo que uma única dose de 9,0 
gramas pode levar à morte. O padrão de potabilidade é fixado pela Portaria 1469 em $0,005 \mathrm{mg} / \mathrm{l}$.

Carbono Orgânico Dissolvido e Absorbância no Ultravioleta - Estes dois parâmetros não estão sujeitos à legislação, mas é importante que sejam rotineiramente avaliados durante um determinado período, para que seja possível obter-se uma correlação, entre estes, com a concentração de compostos precursores de trihalometanos, o que poderá facilitar a detecção quando de possíveis alterações na qualidade da água com relação à presença desse tipo de compostos.

Chumbo - Está presente na água devido às descargas de efluentes industriais, como por exemplo, os efluentes das indústrias de acumuladores (baterias), bem como devido ao uso indevido de tintas e tubulações e acessórios a base de chumbo (materiais de construção). O chumbo e seus compostos também são utilizados em eletrodeposição e metalurgia. Constitui veneno cumulativo, provocando um envenenamento crônico denominado saturnismo, que consiste em efeito sobre o sistema nervoso central com conseqüências bastante sérias. Outros sintomas de uma exposição crônica ao chumbo, quando o efeito ocorre no sistema nervoso central, são: tontura, irritabilidade, dor de cabeça, perda de memória, entre outros. Quando o efeito ocorre no sistema periférico o sintoma é a deficiência dos músculos extensores. A toxicidade do chumbo, quando aguda, é caracterizada pela sede intensa, sabor metálico, inflamação gastrintestinal, vômitos e diarréias.

O chumbo é padrão de potabilidade, sendo fixado o valor máximo permissível de 0,03 mg/l pela Portaria 1469 do Ministério da Saúde. É também padrão de emissão de esgotos e de classificação das águas naturais. Aos peixes, as doses fatais, no geral, variam de 0,1 a $0,4 \mathrm{mg} / \mathrm{l}$.

Cloreto - apresenta-se nas águas subterrâneas, oriundo da percolação da água através de solos e rochas. Nas águas superficiais são fontes importantes as descargas de esgotos sanitários, sendo que cada pessoa expele através da urina cerca $6 \mathrm{~g}$ de 
cloreto por dia, o que faz com que os esgotos apresentem concentrações de cloreto que ultrapassam a $15 \mathrm{mg} / \mathrm{l}$. Diversos são os efluentes industriais que apresentam concentrações de cloreto elevadas como os da indústria do petróleo, algumas indústrias farmacêuticas, curtumes, etc. Nas águas tratadas, a adição de cloro puro ou em solução leva a uma elevação do nível de cloreto, resultante das reações de dissociação do cloro na água.

Para as águas de abastecimento público, a concentração de cloreto constitui-se em padrão de potabilidade, segundo a Portaria 1469 do Ministério da Saúde. O cloreto provoca sabor "salgado" na água, sendo o cloreto de sódio o mais restritivo por provocar sabor em concentrações da ordem de $250 \mathrm{mg} / \mathrm{l}$, valor este que é tomado como padrão de potabilidade. No caso do cloreto de cálcio, o sabor só é perceptível em concentrações de cloreto superior a $1000 \mathrm{mg} / \mathrm{l}$.

O cloreto interfere no tratamento anaeróbio de efluentes industriais, provoca corrosão em estruturas hidráulicas, como por exemplo, em emissários submarinos para a disposição oceânica de esgotos sanitários, que por isso têm sido construídos com polietileno de alta densidade. Interferem na determinação da DQO e embora esta interferência seja atenuada pela adição de sulfato de mercúrio, as análises de DQO da água do mar não apresentam resultados confiáveis. Interfere também na determinação de nitratos.

Eram utilizados como indicadores da contaminação por esgotos sanitários, podendo-se associar a elevação do nível de cloreto em um rio com o lançamento de esgotos sanitários. Hoje, porém, o teste de coliformes fecais é mais preciso para esta função. $\mathrm{O}$ cloreto apresenta também influência nas características dos ecossistemas aquáticos naturais, por provocar alterações na pressão osmótica em células de microrganismos.

Cobre - ocorre geralmente nas águas, naturalmente, em concentrações inferiores a $20 \mathrm{mg} / \mathrm{l}$. Quando em concentrações elevadas, é prejudicial à saúde e confere sabor às águas. Segundo pesquisas efetuadas, é necessária uma concentração de $20 \mathrm{mg} / \mathrm{l}$ de 
cobre ou um teor total de $100 \mathrm{mg} / \mathrm{l}$ por dia na água para produzirem intoxicações humanas com lesões no fígado. No entanto, concentrações de $5 \mathrm{mg} / \mathrm{l}$ tornam a água absolutamente impalatável, devido ao gosto produzido. Em pequenas quantidades é até benéfico ao organismo humano, catalisando a assimilação do ferro e seu aproveitamento na síntese da hemoglobina do sangue humano, facilitando a cura de anemias.

Para os peixes, muito mais que para o homem, as doses elevadas de cobre são extremamente nocivas. Trutas, carpas, bagres, peixes vermelhos de aquários ornamentais e outros, morrem em dosagens de $0,5 \mathrm{mg} / \mathrm{l}$. Os peixes morrem pela coagulação do muco das brânquias e conseqüente asfixia (ação oligodinâmica). Os microrganismos perecem em concentrações superiores a 1,0 mg/l. O Cobre aplicado em sua forma de sulfato de cobre, $\mathrm{CuSO}_{4} \cdot 5 \mathrm{H}_{2} \mathrm{O}$, em dosagens de $0,5 \mathrm{mg} / \mathrm{l}$ é um poderoso algicida. O Water Quality Criteria indica a concentração de 1,0 mg/l de cobre como máxima permissível para águas reservadas para o abastecimento público.

As fontes de cobre para o meio ambiente incluem corrosão de tubulações de latão por águas ácidas, efluentes de estações de tratamento de esgotos, uso de compostos de cobre como algicidas aquáticos, escoamento superficial e contaminação da água subterrânea a partir de usos agrícolas do cobre como fungicida e pesticida no tratamento de solos e efluentes, e precipitação atmosférica de fontes industriais (mineração, fundição e refinação).

Condutividade - é uma expressão numérica da capacidade de uma água conduzir a corrente elétrica. Depende das concentrações iônicas e da temperatura e indica a quantidade de sais existentes na coluna d'água, e, portanto, representa uma medida indireta da concentração de poluentes. Em geral, níveis superiores a $100 \mu \mathrm{S} / \mathrm{cm}$ indicam ambientes impactados.

A condutividade também fornece uma boa indicação das modificações na composição de uma água, especialmente na sua concentração mineral, mas não fornece nenhuma 
indicação das quantidades relativas dos vários componentes. À medida que mais sólidos dissolvidos são adicionados, a condutividade da água aumenta. Altos valores podem indicar características corrosivas da água.

Cromo - A CONAMA 357/2005 restringiu o padrão de qualidade Classe 3 para o mesmo valor do padrão de potabilidade $(0,05 \mathrm{mg} / \mathrm{l})$, optou-se por adotar um nível de concentração para o limite superior que fosse passível de ser removido por meio de tratamento convencional. De acordo com o Drinking Water and Health, 1977, o Cr possui uma taxa de remoção no tratamento convencional variando de 0 a $30 \%$. Aplicando-se uma taxa de remoção média de 15\% ao limite inferior, obtém-se um limite superior de 0,059 mg/l.

Demanda Bioquímica de Oxigênio $\left(\mathrm{DBO}_{5,20}\right)$ - $\mathrm{A} \mathrm{DBO}_{5,20}$ de uma água é a quantidade de oxigênio necessária para oxidar a matéria orgânica por decomposição microbiana aeróbia para uma forma inorgânica estável. $A \mathrm{DBO}_{5,20}$ é normalmente considerada como a quantidade de oxigênio consumido durante um determinado período de tempo, numa temperatura de incubação específica. Um período de tempo de 5 dias numa temperatura de incubação de $20^{\circ} \mathrm{C}$ é freqüentemente usado e referido como $\mathrm{DBO}_{5,20}$.

Os maiores aumentos em termos de $\mathrm{DBO}_{5,20}$, num corpo d'água, são provocados por despejos de origem predominantemente orgânica. A presença de um alto teor de matéria orgânica pode induzir à completa extinção do oxigênio na água, provocando o desaparecimento de peixes e outras formas de vida aquática.

Um elevado valor da $\mathrm{DBO}_{5,20}$ pode indicar um incremento da microflora presente e interferir no equilíbrio da vida aquática, além de produzir sabores e odores desagradáveis e, ainda, pode obstruir os filtros de areia utilizados nas estações de tratamento de água.

No campo do tratamento de esgotos, $a \mathrm{DBO}_{5,20}$ é um parâmetro importante no controle das eficiências das estações, tanto de tratamentos biológicos aeróbios e anaeróbios, 
bem como físico-químicos (embora de fato ocorra demanda de oxigênio apenas nos processos aeróbios, a demanda "potencial" pode ser medida à entrada e à saída de qualquer tipo de tratamento). Na legislação do Estado de São Paulo, o Decreto Estadual n. ${ }^{\circ} 8468$, a $\mathrm{DBO}_{5,20}$ de cinco dias é padrão de emissão de esgotos diretamente nos corpos d'água, sendo exigidos ou uma $\mathrm{DBO}_{5,20}$ máxima de $60 \mathrm{mg} / \mathrm{l}$ ou uma eficiência global mínima do processo de tratamento na remoção de $\mathrm{DBO}_{5,20}$ igual a $80 \%$.

Demanda Química de Oxigênio (DQO) - É a quantidade de oxigênio necessária para oxidação da matéria orgânica através de um agente químico.

O aumento da concentração de DQO num corpo d'água se deve principalmente a despejos de origem industrial.

A DQO é um parâmetro indispensável nos estudos de caracterização de esgotos sanitários e de efluentes industriais. A DQO é muito útil quando utilizada conjuntamente com a $\mathrm{DBO}_{5,20}$ para observar a biodegradabilidade de despejos. Sabe-se que o poder de oxidação do dicromato de potássio é maior do que o que resulta mediante a ação de microrganismos, exceto raríssimos casos como hidrocarbonetos aromáticos e piridina. Desta forma os resultados da DQO de uma amostra são superiores aos de $\mathrm{DBO}_{5,20}$. Como na $\mathrm{DBO}_{5,20}$, se mede apenas a fração biodegradável, quanto mais este valor se aproximar da DQO significa que mais facilmente biodegradável será o efluente

Fenóis - aparecem nas águas naturais através das descargas de efluentes industriais. São tóxicos ao homem, aos organismos aquáticos e aos microrganismos que tomam parte dos sistemas de tratamento de esgotos sanitários e de efluentes industriais.

O índice de fenóis constitui também padrão de emissão de esgotos diretamente no corpo receptor, sendo estipulado o limite de $0,5 \mathrm{mg} / \mathrm{l}$ tanto pela legislação do Estado de São Paulo (Artigo 18 do Decreto Estadual n. ${ }^{\circ}$ 8468/76) quanto pela Legislação Federal (Artigo 21 da Resolução n. ${ }^{\circ}$ 20/86 do CONAMA). 
Nas águas naturais, os padrões para os compostos fenólicos são bastante restritivos, tanto na legislação federal quanto na do Estado de São Paulo. Nas águas tratadas, os fenóis reagem com o cloro livre formando os clorofenóis que produzem sabor e odor na água. Por este motivo, os fenóis constituem-se em padrão de potabilidade, sendo imposto o limite máximo bastante restritivo de $0,001 \mathrm{mg} / \mathrm{L}$ pela Portaria 1469 do Ministério da Saúde.

Ferro Total - aparece principalmente em águas subterrâneas devido à dissolução do minério pelo gás carbônico da água. O carbonato ferroso é solúvel e freqüentemente é encontrado em águas de poços contendo elevados níveis de concentração de ferro. Nas águas superficiais, o nível de ferro aumenta nas estações chuvosas devido ao carreamento de solos e a ocorrência de processos de erosão das margens.

Nas águas tratadas para abastecimento público, o emprego de coagulantes a base de ferro provoca elevação em seu teor.

O ferro, apesar de não se constituir em um tóxico, traz diversos problemas para o abastecimento público de água. Confere cor e sabor à água, provocando manchas em roupas e utensílios sanitários. Também traz o problema do desenvolvimento de depósitos em canalizações e de ferro-bactérias, provocando a contaminação biológica da água na própria rede de distribuição. Por estes motivos, o ferro constitui-se em padrão de potabilidade, tendo sido estabelecida a concentração limite de 0,3 mg/l na Portaria 1469 do Ministério da Saúde. É também padrão de emissão de esgotos e de classificação das águas naturais. No Estado de São Paulo estabelece-se o limite de 15 $\mathrm{mg} / \mathrm{l}$ para concentração de ferro solúvel em efluentes descarregados na rede coletora de esgotos seguidos de tratamento (Decreto no 8468).

No tratamento de águas para abastecimento, deve-se destacar a influência da presença de ferro na etapa de coagulação e floculação. As águas que contêm ferro caracterizamse por apresentar cor elevada e turbidez baixa. Os flocos formados geralmente são pequenos, ditos "pontuais", com velocidades de sedimentação muito baixa. Em muitas 
estações de tratamento de água este problema só é resolvido mediante a aplicação de cloro, a chamada pré-cloração. Através da oxidação do ferro pelo cloro, os flocos tornam-se maiores e a estação passa a apresentar um funcionamento aceitável. No entanto, é conceito clássico que, por outro lado, a pré-cloração de águas deve ser evitada, pois em caso da existência de certos compostos orgânicos chamados precursores, o cloro reage com eles formando trihalometanos, associados ao desenvolvimento do câncer.

Fluoreto - O flúor é o mais eletronegativo de todos os elementos químicos. Tão reativo que nunca é encontrado em sua forma elementar na natureza, sendo normalmente encontrado na sua forma combinada como fluoreto. O flúor é o $17^{\circ}$ elemento em abundância na crosta terrestre representando de 0,06 a $0,9 \%$ e ocorrendo principalmente na forma de fluorita (CaF2), Fluoroapatita (C10(PO4)6) e criolita (Na3AlF6). Porém, para que haja disponibilidade de fluoreto livre, ou seja, disponível biologicamente, são necessárias condições ideais de solo, presença de outros minerais ou outros componentes químicos e água. Traços de fluoreto são normalmente encontrados em águas naturais e concentrações elevadas geralmente estão associadas com fontes subterrâneas. Em locais onde existem minerais ricos em flúor, tais como próximos a montanhas altas ou áreas com depósitos geológicos de origem marinha, concentrações de até $10 \mathrm{mg} / \mathrm{l}$ ou mais são encontradas.

O fluossilicato de sódio era o composto mais utilizado, tendo sido substituído pelo ácido fluossilícico em diversas estações de tratamento de água. Apesar da corrosividade do ácido, o fato de se apresentar na forma líquida facilita sua aplicação e o controle seguro das dosagens, condição fundamental para a fluoretação. O fluoreto de sódio é muito caro e o fluoreto de cálcio, pouco solúvel.

É necessária é a ingestão de 1,5 mg/dia de fluoreto, o que para um consumo de água de 1,2 a 1,6 litros por dia, resulta em concentrações da ordem de $1,0 \mathrm{mg} / \mathrm{l}$. A Organização Mundial de Saúde considera $1,5 \mathrm{mg} / \mathrm{l}$ o valor máximo permissível. 
Fósforo Total - aparece em águas naturais devido, principalmente, às descargas de esgotos sanitários. Nestes, os detergentes superfosfatados empregados em larga escala domesticamente constituem a principal fonte, além da própria matéria fecal, que é rica em proteínas. Alguns efluentes industriais, como os de indústrias de fertilizantes, pesticidas, químicas em geral, conservas alimentícias, abatedouros, frigoríficos e laticínios, apresentam fósforo em quantidades excessivas. As águas drenadas em áreas agrícolas e urbanas também podem provocar a presença excessiva de fósforo em águas naturais.

O fósforo pode se apresentar nas águas sob três formas diferentes. Os fosfatos orgânicos são a forma em que o fósforo compõe moléculas orgânicas, como a de um detergente, por exemplo. Os ortofosfatos são representados pelos radicais, que se combinam com cátions formando sais inorgânicos nas águas e os polifosfatos, ou fosfatos condensados, polímeros de ortofosfatos. Esta terceira forma não é muito importante nos estudos de controle de qualidade das águas, porque sofre hidrólise, convertendo-se rapidamente em ortofosfatos nas águas naturais.

Assim como o nitrogênio, o fósforo constitui-se em um dos principais nutrientes para os processos biológicos, ou seja, é um dos chamados macro-nutrientes, por ser exigido também em grandes quantidades pelas células. Nesta qualidade, torna-se parâmetro imprescindível em programas de caracterização de efluentes industriais que se pretende tratar por processo biológico.

Os esgotos sanitários no Brasil apresentam, tipicamente, concentração de fósforo total na faixa de 6 a $10 \mathrm{mgP} / \mathrm{l}$, não exercendo efeito limitante sobre os tratamentos biológicos. Alguns efluentes industriais, porém, não possuem fósforo em suas composições, ou apresentam concentrações muito baixas. Neste caso, deve-se adicionar artificialmente compostos contendo fósforo como o monoamôneo-fosfato (MAP) que, por ser usado em larga escala como fertilizante, apresenta custo relativamente baixo. Ainda por ser nutriente para processos biológicos, o excesso de 
fósforo em esgotos sanitários e efluentes industriais, conduz a processos de eutrofização das águas naturais.

Manganês - desenvolve coloração negra na água. A concentração de manganês menor que 0,05 mg/l, geralmente é aceitável em mananciais, devido ao fato de não ocorrerem, nesta faixa de concentração, manifestações de manchas negras ou depósitos de seu óxido nos sistemas de abastecimento de água. Raramente atinge concentrações de $1,0 \mathrm{mg} / \mathrm{l}$ em águas superficiais naturais e, normalmente, está presente em quantidades de $0,2 \mathrm{mg} / \mathrm{l}$ ou menos.

Mercúrio - utilizado nos garimpos, no processo de extração do ouro (amálgama). Torna-se um problema ambiental pois, normalmente, nenhuma precaução é tomada e o material acaba por ser descarregado nas águas. É altamente tóxico ao homem, sendo que doses de 3 a 30 gramas são fatais. Apresenta efeito cumulativo e provoca lesões cerebrais. O padrão de potabilidade fixado pela Portaria 1469 do Ministério da Saúde é de $0,001 \mathrm{mg} / \mathrm{l}$. Os efeitos sobre os ecossistemas aquáticos são igualmente sérios, de forma que os padrões de classificação das águas naturais são também bastante restritivos com relação a este parâmetro. As concentrações de mercúrio em águas doces não contaminadas estão normalmente em torno de 50 mg/l.

Entre as fontes antropogênicas de mercúrio no meio aquático destacam-se as indústrias cloro-álcali de células de mercúrio, vários processos de mineração e fundição, efluentes de estações de tratamento de esgotos, fabricação de certos produtos odontológicos e farmacêuticos, indústrias de tintas, etc.

O peixe é um dos maiores contribuintes para a carga de mercúrio no corpo humano, sendo que o mercúrio mostra-se mais tóxico na forma de compostos organo-metálicos. A intoxicação aguda pelo mercúrio, no homem, é caracterizada por náuseas, vômitos, dores abdominais, diarréia, danos nos ossos e morte. Esta intoxicação pode ser fatal em 10 dias. A intoxicação crônica afeta glândulas salivares, rins e altera as funções psicológicas e psicomotoras. 
Níquel - O níquel complexado (niquelcianeto) é tóxico quando em baixos valores de $\mathrm{pH}$. Concentrações de $1,0 \mathrm{mg} / \mathrm{l}$ desse complexo são tóxicas aos organismos de água doce. Concentrações de níquel em águas superficiais naturais podem chegar a aproximadamente $0,1 \mathrm{mg} / \mathrm{l}$, embora concentrações de mais de $11,0 \mathrm{mg} / \mathrm{l}$ possam ser encontradas, principalmente em áreas de mineração. A maior contribuição para o meio ambiente, pela atividade humana, é a queima de combustíveis fósseis. Como contribuintes principais temos também os processos de mineração e fundição do metal, fusão e modelagem de ligas, indústrias de eletrodeposição e, como fontes secundárias, temos fabricação de alimentos, artigos de panificadoras, refrigerantes e sorvetes aromatizados. Doses elevadas de níquel podem causar dermatites nos indivíduos mais sensíveis e afetar nervos cardíacos e respiratórios.

Óleos e Graxas - substâncias orgânicas de origem mineral, vegetal ou animal. Estas substâncias geralmente são hidrocarbonetos, gorduras, ésteres, entre outros. São raramente encontrados em águas naturais, normalmente oriundos de despejos e resíduos industriais, esgotos domésticos, efluentes de oficinas mecânicas, postos de gasolina, estradas e vias públicas.

Os despejos de origem industrial são os que mais contribuem para o aumento de matérias graxas nos corpos d'água. A pequena solubilidade dos óleos e graxas constitui um fator negativo no que se refere à sua degradação em unidades de tratamento de despejos por processos biológicos e, quando presentes em mananciais utilizados para abastecimento público, causam problemas no tratamento d'água. A presença de material graxo nos corpos d'água, além de acarretar problemas de origem estética, diminui a área de contato entre a superfície da água e o ar atmosférico, impedindo, dessa maneira, a transferência do oxigênio da atmosfera para a água. Os óleos e graxas em seu processo de decomposição reduzem o oxigênio dissolvido elevando a DBO5,20 e a DQO, causando alteração no ecossistema aquático. Na legislação brasileira não existe limite estabelecido para esse parâmetro; a recomendação é de que os óleos e as graxas sejam virtualmente ausentes para as classes 1, 2 e 3. 
Ortofosfato Solúvel - Uma vez assimilados, eles são convertidos em fosfato orgânico e em fosfatos condensados. Após a morte de um organismo, os fosfatos condensados são liberados na água. Entretanto, eles não estão disponíveis para absorção biológica até que sejam hidrolizados para ortofosfatos por bactérias.

Oxigênio Dissolvido (OD) - A taxa de reintrodução de oxigênio dissolvido em águas naturais através da superfície, depende das características hidráulicas e é proporcional à velocidade. Outra fonte importante de oxigênio nas águas é a fotossíntese de algas. Este fenômeno ocorre em águas poluídas ou, mais propriamente, em águas eutrofizadas, ou seja, aquelas em que a decomposição dos compostos orgânicos lançados levou à liberação de sais minerais no meio, especialmente os de nitrogênio e fósforo, que são utilizados como nutrientes pelas algas.

A contribuição fotossintética de oxigênio só é expressiva após grande parte da atividade bacteriana na decomposição de matéria orgânica ter ocorrido, bem como após terem se desenvolvido também os protozoários que, além de decompositores, consomem bactérias clarificando as águas e permitindo a penetração de luz. Este efeito pode "mascarar" a avaliação do grau de poluição de uma água, quando se toma por base apenas a concentração de oxigênio dissolvido. Sob este aspecto, águas poluídas são aquelas que apresentam baixa concentração de oxigênio dissolvido (devido ao seu consumo na decomposição de compostos orgânicos), enquanto que as águas limpas apresentam concentrações de oxigênio dissolvido elevadas, chegando até a um pouco abaixo da concentração de saturação.

No entanto, uma água eutrofizada pode apresentar concentrações de oxigênio bem superiores a $10 \mathrm{mg} / \mathrm{l}$, mesmo em temperaturas superiores a $20^{\circ} \mathrm{C}$, caracterizando uma situação de supersaturação. Isto ocorre principalmente em lagos de baixa velocidade, aonde chegam a se formar crostas verdes de algas à superfície. 
Uma adequada provisão de oxigênio dissolvido é essencial para a manutenção de processos de autodepuração em sistemas aquáticos naturais e estações de tratamento de esgotos. Através de medição do teor de oxigênio dissolvido, os efeitos de resíduos oxidáveis sobre águas receptoras e a eficiência do tratamento dos esgotos, durante a oxidação bioquímica, podem ser avaliados. Os níveis de oxigênio dissolvido também indicam a capacidade de um corpo d'água natural manter a vida aquática.

Potencial Hidrogeniônico (pH) - A influência do pH sobre os ecossistemas aquáticos naturais dá-se diretamente devido a seus efeitos sobre a fisiologia das diversas espécies. Também o efeito indireto é muito importante podendo, determinadas condições de $\mathrm{pH}$ contribuírem para a precipitação de elementos químicos tóxicos como metais pesados; outras condições podem exercer efeitos sobre as solubilidades de nutrientes. Desta forma, as restrições de faixas de $\mathrm{pH}$ são estabelecidas para as diversas classes de águas naturais, tanto de acordo com a legislação federal, como pela legislação do Estado de São Paulo (Decreto no 8468/76). Os critérios de proteção à vida aquática fixam o $\mathrm{pH}$ entre 6 e 9 .

Nas estações de tratamento de águas, são várias as unidades cujo controle envolve as determinações de $\mathrm{pH}$. A coagulação e a floculação que a água sofre inicialmente é um processo unitário dependente do $\mathrm{pH}$; existe uma condição denominada "pH ótimo" de floculação que corresponde à situação em que as partículas coloidais apresentam menor quantidade de carga eletrostática superficial. A desinfecção pelo cloro é um outro processo dependente do $\mathrm{pH}$. Em meio ácido, a dissociação do ácido hipocloroso formando hipoclorito é menor, sendo o processo mais eficiente. A própria distribuição da água final é afetada pelo pH. Sabe-se que as águas ácidas são corrosivas, ao passo que as alcalinas são incrustantes. Por isso o pH da água final deve ser controlado, para que os carbonatos presentes sejam equilibrados e não ocorra nenhum dos dois efeitos indesejados mencionados. $\mathrm{O} \mathrm{pH}$ é padrão de potabilidade, devendo as águas para abastecimento público apresentar valores entre 6,5 e 8,5, de acordo com a Portaria 1469 do Ministério da Saúde. Outros processos físico-químicos de tratamento como o abrandamento pela cal, são dependentes do $\mathrm{pH}$. 
$\mathrm{O} \mathrm{pH}$ é um parâmetro importante no controle dos processos físico-químicos de tratamento de efluentes industriais. Constitui-se também em padrão de emissão de esgotos e de efluentes líquidos industriais, tanto pela legislação federal quanto pela estadual. Na legislação do Estado de São Paulo, estabelece-se faixa de pH entre 5 e 9 para o lançamento direto nos corpos receptores (artigo 18 do Decreto 8468/76) e entre 6 e 10 para o lançamento na rede pública seguida de estação de tratamento de esgotos (artigo 19-A).

Potássio - é encontrado em concentrações baixas nas águas naturais já que rochas que contenham potássio são relativamente resistentes às ações do tempo. Entretanto, sais de potássio são largamente usados na indústria e em fertilizantes para agricultura e entram nas águas doces através das descargas industriais e lixiviação das terras agrícolas. É usualmente encontrado na forma iônica e os sais são altamente solúveis. Ele é pronto para ser incorporado em estruturas minerais e acumulado pela biota aquática pois é um elemento nutricional essencial. Concentrações em águas naturais são usualmente menores que $10 \mathrm{mg} / \mathrm{l}$. Concentrações elevadas, da ordem de grandeza de 100 e 25.000 mg/l, podem indicar a ocorrência de fontes quentes e salmouras, respectivamente.

Potencial de Formação de Trihalometanos - A utilização de parâmetros não específicos para avaliar a eficiência de um sistema de tratamento, bem como a qualidade da água de um determinado manancial é uma prática comum nas Estações de Tratamento de Água (ETAs). O parâmetro turbidez, por exemplo, é amplamente utilizado nas ETAs para o controle e o monitoramento operacional da remoção de material particulado. Outros parâmetros deste tipo utilizados comumente são a cor e a densidade de coliformes termotolerantes. Estes parâmetros não específicos podem ser uma valiosa ferramenta para uma primeira avaliação das características daqualidade de águas em mananciais destinados ao abastecimento público. Também podem ser de grande utilidade para verificar rapidamente mudanças na qualidade da água dentro do processo de tratamento. 
Além disso, com a preocupação sobre a formação de compostos organoclorados leves (como por exemplo, clorofórmio) durante o processo de cloração, chamados trihalometanos, torna-se necessária uma avaliação do manancial em relação à quantidade de precursores destes compostos.

A utilização do potencial de formação de trihalometanos como um parâmetro não específico da medida de precursores de THMs, pode comparar a qualidade de vários mananciais de água bruta com potencial para abastecimento, com a possibilidade de produção de concentrações elevadas de THMs em água tratada durante os processos de tratamento e na distribuição.

Série de Nitrogênio (amônia, nitrato, nitrito e nitrogênio orgânico) - São diversas as fontes de nitrogênio nas águas naturais. Os esgotos sanitários constituem em geral a principal fonte, lançando nas águas nitrogênio orgânico devido à presença de proteínas e nitrogênio amoniacal, devido à hidrólise sofrida pela uréia na água. Alguns efluentes industriais também concorrem para as descargas de nitrogênio orgânico e amoniacal nas águas, como algumas indústrias químicas, petroquímicas, siderúrgicas, farmacêuticas, de conservas alimentícias, matadouros, frigoríficos e curtumes.

A atmosfera é outra fonte importante devido a diversos mecanismos: fixação biológica desempenhada por bactérias e algas, que incorporam o nitrogênio atmosférico em seus tecidos, contribuindo para a presença de nitrogênio orgânico nas águas; a fixação química, reação que depende da presença de luz, concorre para as presenças de amônia e nitratos nas águas, as lavagens da atmosfera poluída pelas águas pluviais concorrem para as presenças de partículas contendo nitrogênio orgânico bem como para a dissolução de amônia e nitratos. Nas áreas agrícolas, o escoamento das águas pluviais pelos solos fertilizados também contribui para a presença de diversas formas de nitrogênio. Também nas áreas urbanas, as drenagens de águas pluviais associadas às deficiências do sistema de limpeza pública, constituem fonte difusa de difícil caracterização. 
O nitrogênio pode ser encontrado nas águas nas formas de nitrogênio orgânico, amoniacal, nitrito e nitrato. As duas primeiras chamam-se formas reduzidas e as duas últimas, formas oxidadas. Pode-se associar a idade da poluição com a relação entre as formas de nitrogênio. Ou seja, se for coletada uma amostra de água de um rio poluído e as análises demonstrarem predominância das formas reduzidas significa que o foco de poluição se encontra próximo. Se prevalecer nitrito e nitrato, ao contrário, significa que as descargas de esgotos se encontram distantes. Nas zonas de autodepuração natural em rios, distinguem-se as presenças de nitrogênio orgânico na zona de degradação, amoniacal na zona de decomposição ativa, nitrito na zona de recuperação e nitrato na zona de águas limpas.

Os compostos de nitrogênio são nutrientes para processos biológicos. São tidos como macronutrientes, pois, depois do carbono, o nitrogênio é o elemento exigido em maior quantidade pelas células vivas. Quando descarregados nas águas naturais, conjuntamente com o fósforo e outros nutrientes presentes nos despejos, provoca o enriquecimento do meio tornando-o mais fértil, possibilitando o crescimento em maior extensão dos seres vivos que os utilizam, especialmente as algas, o que é chamado de eutrofização.

Quando as descargas de nutrientes são muito fortes, dá-se o florescimento muito intenso de gêneros que predominam em cada situação em particular. Estas grandes concentrações de algas podem trazer prejuízos aos usos que se possam fazer dessas águas, prejudicando seriamente o abastecimento público ou causando poluição por morte e decomposição.

O controle da eutrofização, através da redução do aporte de nitrogênio é comprometido pela multiplicidade de fontes, algumas muito difíceis de serem controladas como a fixação do nitrogênio atmosférico, por parte de alguns gêneros de algas. Por isso, devese investir preferencialmente no controle das fontes de fósforo. 
O processo de tratamento de esgoto empregado atualmente no Brasil não é otimizado para a remoção de nutrientes e os efluentes finais tratados liberam grandes quantidades destes que também podem dar margem à ocorrência do processo de eutrofização.

Nos reatores biológicos das estações de tratamento de esgotos, o carbono, o nitrogênio e o fósforo, têm que estar em proporções adequadas para possibilitar o crescimento celular sem limitações nutricionais.

Pela legislação federal em vigor, o nitrogênio amoniacal é padrão de classificação das águas naturais e padrão de emissão de esgotos. A amônia é um tóxico bastante restritivo à vida dos peixes, sendo que muitas espécies não suportam concentrações acima de $5 \mathrm{mg} / \mathrm{l}$. Além disso, a amônia provoca consumo de oxigênio dissolvido das águas naturais ao ser oxidada biologicamente, a chamada DBO de segundo estágio. Por estes motivos, a concentração de nitrogênio amoniacal é importante parâmetro de classificação das águas naturais e, normalmente utilizado na constituição de índices de qualidade das águas.

Os nitratos são tóxicos, por isso é padrão de potabilidade, sendo $10 \mathrm{mg} / \mathrm{l}$ o valor máximo permitido pela Portaria 1469.

Sódio - As águas naturais contêm algum sódio já que é um dos elementos mais abundantes na Terra e seus sais são altamente solúveis em água. O aumento dos níveis na superfície da água pode provir de esgotos e efluentes industriais. Concentrações de sódio na superfície natural das águas variam consideravelmente dependendo das condições geológicas do local e descargas de efluentes. Valores podem estender-se de $1 \mathrm{mg} / \mathrm{l}$ ou menos até $10 \mathrm{mg} / \mathrm{l}$. O limite estabelecido para sódio nas águas potáveis é $200 \mathrm{mg} / \mathrm{l}$. Muitas superfícies de água, incluindo aquelas que recebem efluentes, têm níveis bem abaixo de $50 \mathrm{mg} / \mathrm{l}$. Entretanto, as concentrações das águas subterrâneas freqüentemente excedem 50 mg/l. 
Surfactantes - compostos que reagem com o azul de metileno sob certas condições especificadas. Estes compostos são designados "substâncias ativas ao azul de metileno" (MBAS - Metilene Blue Active Substances) e sua concentração é relativa ao sulfonato de alquil benzeno linear (LAS), que é utilizado como padrão na análise.

Os esgotos sanitários possuem de 3 a $6 \mathrm{mg} / \mathrm{l}$ de detergentes. As indústrias de detergentes descarregam efluentes líquidos com cerca de $2000 \mathrm{mg} / \mathrm{l}$ do princípio ativo. As descargas indiscriminadas de detergentes nas águas naturais levam a prejuízos de ordem estética provocados pela formação de espumas. Os detergentes podem exercer efeitos tóxicos sobre os ecossistemas aquáticos. Têm sido responsabilizados também pela aceleração da eutrofização, pois os detergentes comerciais empregados, ricos em fósforo, exercem efeito tóxico sobre o zooplâncton, predador natural das algas.

Zinco - é um elemento essencial para o crescimento, porém, em concentrações acima de 5,0 mg/l, confere sabor à água e uma certa opalescência a águas alcalinas. O efeito tóxico do zinco sobre os peixes é muito conhecido, assim como sobre as algas. O zinco em quantidades adequadas é um elemento essencial e benéfico para o metabolismo humano, sendo que a atividade da insulina e diversos compostos enzimáticos dependem da sua presença.

Os padrões para águas reservadas ao abastecimento público indicam $5,0 \mathrm{mg} / \mathrm{l}$ como o valor máximo permissível. Em águas superficiais, normalmente as concentrações estão na faixa de $<0,001$ a $0,10 \mathrm{mg} / \mathrm{l}$. É largamente utilizado na indústria e pode entrar no meio ambiente através de processos naturais e antropogênicos, entre os quais destacase a produção de zinco primário, combustão de madeira, incineração de resíduos, produção de ferro e aço, efluentes domésticos. A água com alta concentração de zinco tem uma aparência leitosa e produz um sabor metálico ou adstringente quando aquecida. O zinco, por ser um elemento essencial para o ser humano, só se torna prejudicial à saúde quando ingerido em concentrações muito altas, o que é extremamente raro. Neste caso, pode acumular-se em outros tecidos do organismo humano; isso só ocorre quando as taxas de ingestão diária são elevadas. 


\section{VARIÁVEIS MICROBIOLÓGICAS}

\section{Coliformes termotolerantes}

As bactérias do grupo coliforme são consideradas os principais indicadores de contaminação fecal. A determinação da concentração dos coliformes assume importância como parâmetro indicador da possibilidade da existência de microorganismos patogênicos, responsáveis pela transmissão de doenças de veiculação hídrica, tais como febre tifóide, febre paratifóide, desinteria bacilar e cólera.

\section{Cryptosporidium sp e Giardia sp}

As doenças parasitárias representam uma parcela significante de casos de morbidade e mortalidade e, a Giardia lamblia e Cryptosporidium parvum estão entre os protozoários capazes de causar diarréias graves tanto em indivíduos imunocompetentes quanto imunodeficientes. Dentre os vários modos de transmissão destas duas protozooses, a veiculação hídrica tem sido considerada a mais importante, Outro importante aspecto que justifica a avaliação dos protozoários em águas reside no fato de que estes não são eliminados pela ação do cloro.

\section{VARIÁVEIS HIDROBIOLÓGICAS}

Clorofila a - é um dos pigmentos, além dos carotenóides e ficobilinas, responsáveis pelo processo fotossintético. A clorofila a é a mais comum das clorofilas ( $a, b, c, e d)$ e representa, aproximadamente, de 1 a $2 \%$ do peso seco do material orgânico em todas as algas planctônicas e é, por isso, um indicador da biomassa algal. Assim a clorofila a é considerada a principal variável indicadora de estado trófico dos ambientes aquáticos.

A feofitina a é um produto da degradação da clorofila a, que pode interferir grandemente nas medidas deste pigmento, por absorver luz na mesma região do espectro que a clorofila a. 


\section{Comunidades}

O emprego de comunidades biológicas contribui para o caráter ecológico da rede de monitoramento, subsidiando decisões relacionadas à preservação da vida aquática e do ecossistema como um todo.

_ Comunidade fitoplanctônica - pode ser utilizada como indicadora da qualidade da água, principalmente em reservatórios, e, a análise da sua estrutura permite avaliar alguns efeitos decorrentes alterações ambientais. Esta comunidade é a base da cadeia alimentar e, portanto, a produtividade dos elos seguintes depende da sua biomassa.

Os organismos fitoplanctônicos respondem rapidamente (em dias) às alterações ambientais decorrentes da interferência antrópica ou natural. É uma comunidade indicadora do estado trófico, podendo ainda ser utilizada como indicador de poluição por pesticidas ou metais pesados (presença de espécies resistentes ao cobre) em reservatórios utilizados para abastecimento.

A presença de algumas espécies em altas densidades pode comprometer a qualidade das águas, causando restrições ao seu tratamento e distribuição. Atenção especial é dada ao grupo das Cianofíceas, também denominadas Cianobactérias, que possui espécies potencialmente tóxicas. A ocorrência destas algas tem sido relacionada a eventos de mortandade de animais e com danos à saúde humana (Chorus \& Bartran, 1999 apud CETESB, 2003).

_ Comunidade zooplanctônica - é formada por animais microscópicos que vivem em suspensão, tais como protozoários, rotíferos, cladóceros e copépodes os grupos dominantes no ambiente de água doce. São importantes na manutenção do equilíbrio do ambiente aquático, podendo atuar como reguladores da comunidade fitoplanctônica (utilizando-a como alimento) e na reciclagem de nutrientes, além de servirem de alimento para diversas espécies de peixes. 
O zooplâncton vem sendo avaliado como indicador da qualidade da água de lagos e reservatórios em diversos países e, apesar de existirem algumas propostas de índices para esta comunidade, a maioria deles não é diretamente aplicável nos ambientes aquáticos tropicais, onde as espécies exibem diferente sensibilidade e ocorrência.

_ Comunidade bentônica - corresponde ao conjunto de organismos que vivem todo ou parte de seu ciclo de vida no substrato de fundo de ambientes aquáticos. Os macroinvertebrados que compõem essa comunidade têm sido sistematicamente utilizados em redes de biomonitoramento em vários países, porque ocorrem em todo tipo de ecossistema aquático, exibem ampla variedade de tolerâncias a vários graus e tipos de poluição, têm baixa motilidade e estão continuamente sujeitos às alterações de qualidade do ambiente aquático, inserindo o componente temporal ao diagnóstico e, como monitores contínuos, possibilitam a avaliação em longo prazo dos efeitos de descargas regulares, intermitentes e difusas, de concentrações variáveis de poluentes, de poluição simples ou múltipla e de efeitos sinergísticos e antagônicos de contaminantes. Nos reservatórios, as comunidades de duas zonas de estudo foram consideradas, sublitoral e profundal. A primeira, mais sensível a degradação recente, ou seja, a contaminantes presentes na coluna d'água, e a segunda ao histórico de degradação local, associada a contaminantes acumulados nos sedimentos.

\section{VARIÁVEIS ECOTOXICOLÓGICAS}

Ensaios Ecotoxicológicos - Com vistas ao aprimoramento das informações referentes à qualidade das águas, a CETESB realiza, desde 1992, ensaios ecotoxicológicos com organismos aquáticos. Esses ensaios consistem na determinação de efeitos tóxicos causados por um ou por uma mistura de agentes químicos, sendo tais efeitos detectados por respostas fisiológicas de organismos aquáticos. Portanto, os ensaios ecotoxicológicos expressam os efeitos adversos, a organismos aquáticos, resultantes da interação das substâncias presentes na amostra analisada. 
A CETESB avalia os efeitos tóxicos agudos e crônicos no monitoramento da qualidade das águas, bem como no dos sedimentos. Os efeitos agudos caracterizam-se por serem mais drásticos, causados por elevadas concentrações de agentes químicos, e em geral manifestam-se em um curto período de exposição dos organismos. Os efeitos crônicos são mais sutis, causados por baixas concentrações de agentes químicos dissolvidos, e são detectados em prolongados períodos de exposição ou por respostas fisiológicas adversas na reprodução e crescimento dos organismos vivos.

Os ensaios ecotoxicológicos utilizados, bem como suas características, são:

_ Ensaio de toxicidade aguda com a bactéria luminescente - Vibrio fischeri (Sistema Microtox) - é utilizado para avaliar a ocorrência de efeitos agudos em corpos d'água onde o oxigênio dissolvido apresenta-se muito baixo, como é o caso de trechos de rios localizados na zona metropolitana de São Paulo. O resultado do ensaio é expresso em CE20, que é a concentração da amostra que causa inibição de $20 \%$ da emissão do luz emitida pelo microrganismo. Assim, quanto menor o valor da CE20 mais tóxica é a amostra analisada.

_ Ensaio de toxicidade aguda/crônica com o microcrustáceo Ceriodaphnia dúbia - é utilizado para avaliar a ocorrência de efeitos tóxicos, agudos ou crônicos, em corpos d'água para os quais está prevista a preservação da vida aquática. O resultado do ensaio é expresso como agudo (quando ocorre letalidade de número significativo de organismos, dentro do período de 48 horas) ou crônico (quando ocorre inibição na reprodução dos organismos, dentro do período de sete dias). A amostra é considerada não tóxica caso não haja detecção de qualquer dos efeitos tóxicos.

_ Ensaio de toxicidade aguda/crônica com o anfípodo Hyalella azteca - é utilizado para avaliar a ocorrência de efeitos tóxicos, agudos ou crônicos, em sedimentos coletados em recursos hídricos para os quais está prevista a preservação da vida aquática. $O$ resultado do ensaio é expresso como agudo (quando ocorre letalidade de número significativo de organismos, dentro do período de 10 dias) ou crônico (quando ocorre inibição do crescimento de um número significativo de organismos, dentro do período 
de 10 dias). A amostra é considerada não tóxica caso não haja detecção de qualquer dos efeitos tóxicos.

_ Ensaios de Genotoxicidade - medem a capacidade de um composto ou mistura de causar dano ao material genético. Danos genéticos não reparados geram mutações nos organismos expostos as quais podem causar doenças como câncer, anemia, distúrbios cardiovasculares e neurocomportamentais, além de doenças hereditárias.

A CETESB utiliza o ensaio de mutação reversa (conhecido como teste de Ames ou ensaio Salmonella/microsoma), o qual é eficiente para detectar uma grande variedade de compostos mutagênicos.

As linhagens bacterianas utilizadas no teste apresentam características que as tornam mais sensíveis para detecção de mutações e o uso de diferentes linhagens na presença e ausência de sistema de metabolização in vitro pode fornecer informações importantes sobre a classe de compostos que estão presentes nas amostras avaliadas.

Para amostras ambientais, os resultados do teste de Ames são expressos em número de revertentes (bactérias que sofreram mutações) por litro ou grama equivalente de amostra e quanto maior esse número, maior a quantidade ou a potência de compostos mutagênicos na amostra analisada. Consideram-se amostras de corpos d'água com 0 a 500 revertentes/litro com atividade mutagênica baixa; de 500 a 2500 - moderada; de 2500 a 5000 - alta; e valores maiores que 5000 - extrema.

Amostras de mananciais utilizados para abastecimento público, que apresentam atividade mutagênica, sugerem a necessidade de níveis de tratamento diferenciados, bem como requerem a redução das fontes de contaminação nas ETAs. 